\title{
Productivity Growth: Patterns and Determinants across the World
}

\author{
Young Eun Kimª ${ }^{\mathrm{a}}$ Norman V. Loayza ${ }^{\mathrm{b}, \boldsymbol{x}}$ \\ ${ }^{a}$ Development Research Group, World Bank \\ $\bowtie$ ykim10@worldbank.org \\ ${ }^{\mathrm{b}}$ Development Research Group, World Bank \\ $\bowtie$ nloayza@worldbank.org "Corresponding author
}

\begin{abstract}
This is the background paper for the productivity extension of the World Bank's Long-Term Growth Model (LTGM). Based on an extensive literature review, the paper identifies the main determinants of economic productivity as innovation, education, market efficiency, infrastructure, and institutions. Based on underlying proxies, the paper constructs indexes representing each of the main categories of productivity determinants and, combining them through principal component analysis, obtains an overall determinant index. This is done for every year in the three decades spanning 1985-2015 and for more than 100 countries. In parallel, the paper presents a measure of total factor productivity (TFP), largely obtained from the Penn World Table, and assesses the pattern of productivity growth across regions and income groups over the same sample. The paper then examines the relationship between the measures of TFP and its determinants. The variance of productivity growth is decomposed into the share explained by each of its main determinants, and the relationship between productivity growth and the overall determinant index is identified. The variance decomposition results show that the highest contributor among the determinants to the variance in TFP growth is market efficiency for Organisation for Economic Co-operation and Development countries and education for developing countries in the most recent decade. The regression results indicate that, controlling for country- and time-specific effects, TFP growth has a positive and significant relationship with the proposed TFP determinant index and a negative relationship with initial TFP. This relationship is then used to provide a set of simulations on the potential path of TFP growth if certain improvements on TFP determinants are achieved. The paper presents and discusses some of these simulations for groups of countries by geographic region and income level. In addition, as a country-specific illustration, the paper presents simulations on the potential path of TFP growth for Peru under various scenarios. An accompanying Excelbased toolkit, linked to the LTGM, provides a larger set of simulations and scenario analysis at the country level for the next few decades.
\end{abstract}

Article History: Received: March 62019 / Revised: May 22019 / Accepted: May 172019

Keywords: Productivity; Innovation; Education; Efficiency; Infrastructure; Institutions; Growth.

JEL Classification: D24, G14, H54, I25, O33, O43, O47 


\section{Acknowledgements}

For helpful comments, we would like to thank Wen Chen, Steven Michael Pennings, Jorge Luis Guzman Correa, Zixi Liu, Ha Nguyen, Luis Servén, Rongsheng Tang, Yong Wang, and participants in seminars at the World Bank, the Federation of ASEAN Economic Associations, the Shanghai University of Finance and Economics, and Peking University.

We are also grateful for insightful comments and advice from Gabriel Rodríguez, Editor of the Journal, and three anonymous referees. The views expressed herein are those of the authors and do not necessarily reflect the views of the World Bank, its Executive Directors, or the countries they represent.

"It is not by augmenting the capital of the country, but by rendering a greater part of that capital active and productive than would otherwise be so, that the most judicious operations of banking can increase the industry of the country." Adam Smith, An Inquiry into the Nature and Causes of the Wealth of Nations (page 131).

\section{Introduction}

With the same amount of inputs - including labor, human and physical capital, and materials some countries, sectors, and firms produce more and others less. This difference depends on how productive they are in allocating and using resources in the production process. One of the most important lessons in economics is that productivity improvement is key to sustained economic growth. (See, among others, Hall and Jones, 1999; Easterly and Levine, 2001; Caselli, 2005).

Productivity was a main concern of the fathers of modern economics, Adam Smith and David Ricardo, in the eighteenth century, as they considered the advantages of specialization and trade as the basis for the wealth of nations. In the first half of the twentieth century, as advanced economies started to recover from the Great Depression, Hicks (1939) and Schumpeter (1942) emphasized the importance of productivity improvements, linking them to enterprise renewal and "creative destruction". When economists turned their attention to developing countries, they described productivity growth as crucial in the search for sustained growth and development. For Lewis (1954); Kuznets (1957), and Chenery (1960), economic development required a structural transformation that shifted resources from less to more productive sectors of the economy. More recently, since the productivity slowdown in developed countries in the 1970s, the lackluster growth of developing countries in the 1980s, and the collapse of the communist regimes in Eastern Europe and East Asia in the early 1990s, interest in understanding the sources of growth and productivity has grown exponentially (see Woo et al., 1997; Ben-David and Papell, 1998; Easterly, 2001; Jorgenson et al., 2008).

Placing the study of productivity in the context of economic growth research may bring about important insights. In the 1950s, Solow and Swan developed a growth model in which changes in physical capital, labor, and total factor productivity (TFP) determine the economy's growth rate (Solow, 1956; Swan, 1956). It has proven to be a workhorse of growth theory and applications for over 50 years. A drawback of this model, however, is that the path of TFP is assumed to be exogenous. At least since the mid-1980s, theoretical economists have addressed this 
shortcoming. For example, Romer (1987, 1990); Grossman and Helpman (1991), and Aghion and Howitt (1992) incorporated technological advance through research and development (R\&D) as a driver of long-run growth. Lucas (1988) argued that the accumulation of human capital through education creates a positive externality that drives productivity, which in turn explains long-run growth. Rebelo (1991) included both human and physical capital in a composite measure that faces no decreasing returns, suggesting that continuous investment can lead to long-term growth. Barro (1990) and Barro and Sala-I-Martin (1992) incorporated tax-financed public goods and assumed that they complement private capital, so that concurrent investment in both public and private capital could lead to growth in the long run. Engerman and Sokoloff (2000) and Acemoglu et al. $(2001,2004)$ deepen the notion of public goods to argue that the role of political and economic institutions is fundamental to economic growth. It can be said that in all these cases, the proposed mechanisms driving productivity are ways of explaining economic growth in the long run without resorting to exogenous changes.

The interest in understanding the microeconomic foundations of aggregate behavior has also led to important insights on productivity. Hopenhayn (1992); Hopenhayn and Rogerson (1993); Caballero and Hammour (1996), and Davis et al. (1996) pioneered research on the role of firm dynamics driving productivity and, consequently, economic growth. The conclusion from this extensive body of research is that resource reallocation (including firm entry and exit, innovation and renewal, and structural transformation) explains a substantial share of productivity improvement in the economy. Resource reallocation requires, however, a costly adjustment: the adoption of new technologies, the assimilation of production inputs by expanding firms, and the shedding of labor and capital by declining firms. Differences in the ease of resource reallocation can then explain why some countries are more productive than others. These differences can be related to the level of development of the country (e.g., lack of human capital and functioning justice system; see Caballero and Hammour (1998) and Acemoglu and Zilibotti, 2001) and to the quality of government's regulations and interventions (e.g., excessive labor regulations, subsidies to inefficient sectors, and barriers of firm entry and exit; see Parente and Prescott, 2000). Although more refined in the mechanisms, the microfoundations literature points to the same conclusions as the aggregate literature highlighted above, regarding the roles of innovation, education, regulatory environment, and public goods and institutions in driving productivity.

The surge in theoretical research on economic growth and productivity has been paralleled by an enormous empirical literature. A selected review is offered in the second section of the paper. In brief, this empirical research attempted to, first, test the validity of recent growth theories in contrast to (or in conjunction with) the neoclassical growth theory, and, second, determine the quantitative importance of various proposed drivers of growth. The first wave of empirical studies on new growth research focused on aggregate, cross-country data. In academic circles, this line of work is best exemplified by the seminal study of Barro (1991). In the World Bank and other policy-oriented organizations, empirical studies such as Easterly and Levine (1997, 2001); Loayza et al. (2005); Loayza and Servén (2010) offered a guide for understanding economic growth and its determinants, including policies and institutions. As micro-level data became more widely available in the 1990s, a second wave of empirical research used data at the industry and firm

\section{PUCP}


levels to study firm renewal, resource redistribution, and structural transformation. This led to insights and findings that could not have been obtained using country-level data, as shown in Foster et al. (2001); Restuccia and Rogerson (2008), and Hsieh and Klenow (2009).

Considering numerous studies on economic growth and productivity published in the past few decades, in this paper we take stock of the main conceptual conclusions surrounding productivity growth and synthesize the quantitative implications through original data collection and analysis. Apart from its independent contribution, this paper serves as background for an extension of the World Bank Long-Term Growth Model (Loayza and Pennings, 2018). This extension quantifies how changes in TFP growth are driven by changes in its underlying determinants, and, in turn, how changes in TFP growth lead to different paths for economic growth.

The drivers of productivity growth can be grouped into five components (Kim et al., 2016): innovation, to create and adopt new technologies; education, to spread these new technologies throughout the economy and to develop the capacity of the workforce to assimilate them; market efficiency, to promote the effective and flexible allocation of resources across sectors and firms; infrastructure (in transport, telecommunication, energy, and water and sanitation), to support and facilitate the economic activity of households, businesses, and markets; and institutions (in the regulatory, justice, policy, and political systems), to provide social and economic stability, to defend property rights, and to safeguard basic civil rights. These five components are interrelated and can clearly influence one another.

In this paper we identify the main determinants of productivity growth, propose proxies to measure them, assess the pattern of TFP growth across regions and over time, and quantify the relationship between the TFP determinants proxies and TFP growth. For this purpose, we first conduct an extensive literature review on productivity that considers not only concepts and theories but also empirical studies. Then, we estimate TFP and construct indexes representing each of the five main determinants of TFP for a large group of countries in the past three decades (from 1985 to 2014). Finally, we measure the relative contribution of each of the main determinants to the variance of TFP growth, and we estimate their overall effect on TFP growth. As mentioned above, these results are used to build a TFP module for the extended Long-Term Growth Model (LGTM).

In the rest of the paper, section 2 presents a review of the literature; this is important because it not only frames the context of the paper but also helps to identify and categorize the drivers of TFP growth. Section 3 describes the methodology, including the selection of countries and variables, the estimation of TFP, the construction of indexes to measure each TFP determinant category, and the variance decomposition and regression analysis. Section 4 presents and discusses the main results, from descriptive statistics to regression analysis. Section 5 uses the main results to generate simulations on the path of TFP growth if certain reforms are accomplished. Section 6 concludes. 


\section{Literature Review}

To identify and categorize the main determinants of TFP, we conduct a literature review spanning papers published from 1990 to 2016. We start with the reviews conducted by Isaksson (2007) and Syverson (2011) and expand the search further by using the key terms "total factor productivity", "economic growth", and "determinants". We filter papers based on abstracts and main texts, choosing those that present a quantitative relationship between productivity and its potential determinants, using evidence from developing and developed countries. We select papers that examine time-variant determinants that a country can improve either through market forces or by public policy decision and implementation. (See Appendix A for the full list of the papers.) Based on the literature review, the main determinants of productivity are categorized into five components: innovation, education, market efficiency, infrastructure, and institutions (Kim et al., 2016).

\section{Innovation}

Innovation, as the generation and adoption of new technologies, leads to the development of higher value-added activities, products, and processes and improves the performance of existing ones. Historically, a small number of countries have created new technologies based on investment in research and development $(\mathrm{R} \& \mathrm{D})$ by the public and private sectors and an advanced level of human capacity and physical capital (Furman et al., 2004; Griffith et al., 2004). Other countries have then adapted and adopted technological changes, with varying time lags and degrees of intensity (Comin and Hobijn, 2008).

Using indicators such as investment in $R \& D$, the number of patents, and the number of scientific and technological journal publications, many studies show that the creation or adoption of a new technology is positively associated with TFP growth (see, for example, Nadiri, 1993; Chen and Dahlman, 2004; Guellec and van Pottelsberghe de la Potterie, 2004). For instance, Jorgenson et al. (2008) and Oliner et al. (2008) show that Information and Communication Technologies (ICT) played a central role in accelerating productivity in the United States (U.S.) from the mid-1990s to the 2000s after the lackluster pace of productivity growth in the 1970s and 1980s. The comparison of Europe and the U.S. highlights the critical role of new technologies in expanding productivity. van Ark et al. (2008) show that the productivity slowdown in Europe during the 1990s and 2000s is attributable to the lower contribution of ICT to growth, the smaller share of technology-producing industries, and slower advances in technology and innovation as compared to the U.S. Not only the development of new technologies but also the adoption of existing ones play a substantial role in enhancing productivity and income growth. Comin and Hobijn (2010) and Comin and Mestieri (2018), using data on the diffusion of more than 15 technologies across a large number of countries over the last two centuries, show that varying patterns of the adoption and diffusion of technologies since 1820 account for at least 25 percent of the income divergence across countries and 75 percent of the income difference between rich and poor countries.

\section{PUCP}




\section{Education}

Education, as the knowledge and skills of the population, is essential to generate new technologies, as well as to disseminate, adapt, and implement them throughout the economy. Education allows workers not only to produce more and better, but also to expand and disseminate the technological frontier. For education to contribute to productivity, it must consist of strong basic foundations and sufficient specialization, rich in both quantity and quality, and spread throughout the population (Barro, 2001; Hanushek and Woessmann, 2015).

Studies suggest that indicators such as the number of schooling years and the completion rate of secondary and tertiary education of the population are associated with output growth through both TFP improvements and the direct contribution of human capital (Benhabib and Spiegel, 1994; Griffith et al., 2004; Bronzini and Piselli, 2009; Erosa et al., 2010). Having a sufficiently high level of education increases productivity growth in developing countries by enabling them to adopt new technologies from frontier countries. Benhabib and Spiegel (2005), for example, show that a country's average years of schooling (as a proxy for education) has a positive impact on TFP growth through technology catch-up. Miller et al. (2000) show that education (also using the years of schooling as a proxy) can affect how developing countries adopt new technologies through trade, with a positive impact on TFP. Barro (2001) shows in a study of around 100 countries that the quantity and quality of education, using the years of schooling and student test scores as respective proxies, are significantly related to economic growth. Wei and Hao (2011) show that education quality, using government expenditure on education and teacher-student ratio as proxies, is significantly associated with TFP growth in China.

\section{Market Efficiency}

Market efficiency, defined as the efficient allocation of resources (e.g., labor, capital, and materials) across firms and sectors, enhances TFP by inducing unproductive firms to exit the market, facilitating productive firms to grow, and allowing new firms to emerge (Foster et al., 2001; Hsieh and Klenow, 2009; Parente and Prescott, 2000; Restuccia and Rogerson, 2017). Market efficiency has several components, including the proper functioning of output markets, financial systems, and labor markets.

A number of studies find that market efficiency is associated with variation in productivity across firms, sectors, and countries. Jerzmanowski (2007) shows that inefficiency in the allocation of human and physical capital is the main explanation for low income level among around 80 countries from 1960 to 1995. Hsieh and Klenow (2009) estimate that, if capital and labor had been allocated at the relatively efficient level of the U.S., productivity in manufacturing sectors could have been 1.3 times higher for China and 1.6 times higher for India in 2005. Melitz (2003) shows that exposure to trade induces more productive firms to enter the export market and the least productive firms to exit, leading to an increase in aggregate industry productivity growth. The quality of the regulatory framework matters significantly for the ease of resource reallocation, including firm dynamics and structural transformation (Djankov et al., 2002; Loayza and Servén, 2010). Drawing the link between shortcomings in technological adoption and burdensome 
regulations, Bergoeing et al. (2016) argue that regulatory barriers of firm entry and exit account for 26 to 60 percent of the income gap between the United States and 107 developing countries and that not just removing these barriers but removing them jointly is critical. Nicoletti and Scarpetta (2003) and Arnold et al. (2008) show that burdensome market regulations, as well as and the lack of reforms for promoting private corporate governance and competition, caused industries that use or produce ICT to have meager productivity levels in several European countries and deterred firms from catching up to the international technological frontier.

Regarding financial systems, Rajan and Zingales (1988) show that financial development facilitates economic growth by reducing the costs of external finance to firms for a large number of countries in the 1980s. Beck et al. (2000) argue that financial development affects economic growth mainly through its positive effect on TFP. Buera et al. (2011) show that financial frictions distort the allocation of capital and entrepreneurial talent across production units, adversely affecting TFP and sectoral relative productivity. With respect to labor markets, studies show that regulations that provide flexibility in the allocation of labor enhance productivity. Haltiwanger et al. (2008) and Bartelsman et al. (2016) show that employment protection regulations preclude efficient labor reallocation because they curb job flows or discourage firms from adopting risky but highly productive technologies. Barro (2001) shows that the education of female students has an insignificant impact on economic growth unlike that of male students, suggesting that labor market reforms to incorporate female workers has a potential to increase TFP.

\section{Infraestructure}

Public infrastructure - in transport, telecommunication, energy, and water and sanitationcan provide timely and cost-effective access to input and output markets, workplaces, and knowledge and information sources, thus supporting all possible economic activities (Straub, 2008; Galiani et al., 2005). An appropriate infrastructure network - in terms of quantity, quality, and diversity - can complement private capital and labor, increasing their returns and impact on economic growth. In this way, expanding public infrastructure becomes a source of TFP growth.

The evidence that appropriate public infrastructure has a positive impact on productivity and economic growth is convincing. Hulten (1996) shows that 25 percent of the growth difference between East Asia and Africa over 1970-90 is explained by the efficient use of infrastructure. Aschauer (1989) argues that public capital stock, especially core infrastructure such as highways, airports, sewers, and water systems, was critical in determining productivity in the U.S. over 1950s-1980s. Straub (2008) shows in a study of 140 countries over 1989-2007 that the infrastructure stock has a positive external impact on growth, for example, by allowing firms to invest in more productive machineries, decreasing workers' commuting times, and promoting health and education. Considering also a panel of countries over time, Calderón and Servén (2010, 2012, 2014) argue persuasively that infrastructure can have positive effects on both growth and distributive equity. These beneficial effects, however, require a framework that regulates, organizes, and coordinates the governments and companies that build public infrastructure and provide its services. Moreover, as highlighted by Pritchett (1996) and Devadas and Pennings (2018), the amount of infrastructure spending is not necessarily an indication of effective infrastructure

\section{; PUCP}


investment. The quality of spending matters, and this seems to be highly related to the strength of public institutions (World Bank, 2003, 2017r).

\section{Institutions}

Public Institutions - in the regulatory, justice, policy, and political systems - can promote social and economic stability, provide a safe living and working environment, defend property rights, and safeguard basic civil rights. The environment and policies that public institutions provide have a large, fundamental impact on economic development (North, 1990; Acemoglu et al., 2004). The evidence that good governance (reflected in political stability, the rule of law, the protection of property rights, bureaucratic quality, transparency and accountability, and the absence of corruption) has a positive effect on productivity and economic growth is large, comprehensive, and convincing.

Barro (1991) shows in a study of around 100 countries for 1960-85 that economic growth is positively related to political stability and inversely to government-induced market distortions. Using ethnolinguistic fractionalization as an instrumental variable for measures of government corruption, Mauro (1995) finds that corruption has a statistically significant and economically large negative effect on economic growth. Knack and Keefer (1995) find that property rights, proxied by contract enforceability and risk of expropriation, has a substantial impact on economic growth, even after accounting for capital accumulation. Rodrik et al. (2004) show that the quality of institutions, measured by a composite indicator of the protection of property rights and the rule of law, has a positive impact on income levels across a large sample of countries. Chanda and Dalgaard (2008) find that the quality of institutions (proxied by a composite index of the rule of law, bureaucratic quality, corruption, the risk of expropriation, and the government repudiation of contracts) is positively related to productivity. Easterly and Levine (2003) show that institutions is a channel for geographical endowments to have an impact on economic development. They also show that when institutional quality is controlled for, macroeconomic policies do not account for development, implying good governance leads to conducive macroeconomic environments.

The five categories of TFP determinants presented above span a comprehensive array of factors driving productivity. They are also the channels through which other potential variables affect TFP. Some of them are time-invariant, such as historical origins and geographic conditions. Their effect is captured by our proposed determinants. For example, Rodrik et al. (2004) show that geography has an impact on incomes by influencing the quality of institutions. Other potential variables account for slow-moving processes, such as social mobility and income inequality. Their effect on TFP growth, however, can be explained by education, market efficiency, and governance. Consider, as illustration, the following papers. Cingano (2014) shows that income inequality has a negative impact on economic growth by impeding skill development among individuals with poorer parental education background. Dabla-norris and Kochhar (2015) show that low-income households and small firms face difficulties in accessing financial services, which decreases economic growth. Hoeller et al. (2014) argue that the lack of policies that provide more inclusive access to education, financial services, and labor markets leads to income inequality, and eventually lower economic growth. 


\section{Methods}

First, we present the sample of countries and years included in the analysis. Second, we report how TFP growth at the country level is estimated. Third, we construct a set of indexes representing each of the main productivity determinants; we then obtain an overall index by grouping the indexes together. Fourth, we analyze the relationship between TFP growth and the proposed indexes of TFP determinants.

\subsection{Sample}

We conduct the statistical analysis using a sample of 98 developing and developed countries for the period 1985-2014. They are selected from the larger sample of countries featured in the Penn World Table (PWT) 9.0 and the World Bank World Development Indicators (WDI) databases. We exclude countries that do not have a minimal set of historical data for statistical analysis, countries that depend heavily on oil production (because the contribution of oil to output could result in a large overestimation of TFP growth $)^{1}$, and small countries, defined as those with population less than 2 million (in 2016) (World Bank, 2017m).

For the descriptive analysis of TFP growth across regions and decades (in section 4.1), we add 16 countries for which data on the share of labor in income is missing in PWT 9.0 but available from the Global Trade Analysis Project (GTAP) 9.0 (Aguiar et al., 2016). For the descriptive analysis of TFP determinants (in section 4.2), we additionally include 22 countries, which, though not having information to obtain TFP estimates, do have data for the proposed determinant indicators. For growth projections in the Long-Term Growth Model (LTGM), we add back small countries, heavily oil dependent countries, and those for which we can complete missing data from other sources and additional assumptions; thus, the TFP extension of the LTGM can be applied to about 190 countries for growth projections.

We classify high-income countries that have been members of OECD for more than 40 years as the OECD group. The rest of countries are classified by region and income. We use the average of GDP per capita (World Bank, 2017e) over 1985-2014 to break the sample into income quintiles. Table B.1 shows the country list by region and income quintile groups, indicating their inclusion in the samples by type of analysis (descriptive and statistical), data source (PWT, GTAP, and WDI), and other characteristics (oil rent and population).

\subsection{Construction of Total Factor Productivity}

Total factor productivity is commonly measured as a residual, that is, the portion of GDP that remains after accounting for the direct contributions of capital and labor inputs in total GDP (Barro and Sala-I-Martin, 2004). The aggregate capital stock is usually computed through the perpetual-inventory method, as the accumulation of gross physical investment (from a given

\footnotetext{
${ }^{1}$ Heavy dependence is defined as reliance on oil production for more than 32 percent of GDP on average during 2006-15, which is 90th - 100th percentile among 98 countries with positive oil rents (World Bank, 2017j); Angola (45\%), Congo, Rep. (46\%), Equatorial Guinea (42\%), Gabon (32\%), Iraq (52\%), Kuwait (47\%), Libya (54\%), Oman (37\%), Saudi Arabia (44\%), and South Sudan (45\%).
} 
initial capital stock), discounting the depreciation of existing stocks. Labor input can be calculated as the number of employed people, adjusted for human capital. The capital share is the fraction of total GDP used to pay for capital, and the labor share is the fraction of total GDP used to pay for labor. The shares of each factor of production are often assumed to be constant over time.

For the level of (relative) TFP, we use the estimate provided in Penn World Table (PWT) 9.0, labeled rtfpna (Feenstra et al., 2015). This series is obtained by setting the TFP level of 2011 equal to 1 , and then computing the remaining TFP levels backwards and forwards by applying the TFP growth rates. The TFP growth rates are obtained implicitly through the following equations:

$$
\frac{R T F P_{j t}^{N A}}{R T F P_{j t-1}^{N A}}=\frac{R G D P_{j t}^{N A}}{R G D P_{j t-1}^{N A}} / Q_{j t, t-1},
$$

where

$$
\begin{aligned}
Q_{j t, t-1}= & \frac{1}{2}\left(L A B S H_{j t}+L A B S H_{j t-1}\right)\left(\frac{E M P_{j t}}{E M P_{j t-1}} \frac{H C_{j t}}{H C_{j t-1}}\right) \\
& +\left[1-\frac{1}{2}\left(L A B S H_{j t}+L A B S H_{j t-1}\right)\right]\left(\frac{R K_{j t}^{N A}}{R K_{j t-1}^{N A}}\right) .
\end{aligned}
$$

$R T F P^{N A}$ : TFP level, computed with $R G D P^{N A}, R K^{N A}, E M P, H C$, and $L A B S H$. $R G D P^{N A}$ : Real GDP at constant national prices.

$R K^{N A}$ : Capital stock at constant national prices.

$E M P$ : The number of people employed.

$H C$ : Human capital based on the average years of schooling from Barro and Lee (2013) and an assumed rate for primary, secondary, and tertiary education from Caselli (2005).

$L A B S H$ : The share of labor income of employees and self-employed workers in GDP.

$j$ : country, and $t$ : year.

For our analysis, we calculate annual TFP growth rates by differencing the log-transformed TFP levels of year $t$ and $t-1, \ln \left(r t f p n a_{t}\right)-\ln \left(r t f p n a_{t-1}\right)$.

As a robustness check, we calculate TFP using mainly data from the World Development Indicators database (instead of PWT). In Appendix E, we compare the results (on descriptive statistics and econometric analysis) using this alternative TFP measure.

\subsection{Construction of Main Determinant Indexes}

We construct subcomponent indexes that represent each of the five determinants - innovation, education, market efficiency, infrastructure, and institutions - and an overall index representing the five determinants all together. First, to construct a subcomponent index, we select relevant indicators and combine them using factor analysis, which captures as much of common variance in the indicators as possible in a single index (Figure 1.A) (Mulaik, 2009).

Then, to construct an overall determinant index, we combine the five subcomponent indexes using principal component analysis (PCA), which captures as much of total variance in the five 


\section{A. Factor analysis}

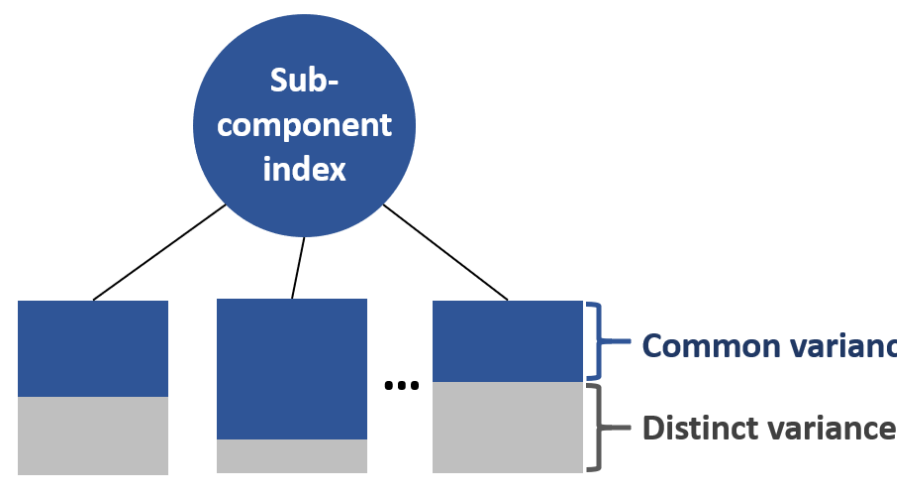

Indicator 1 Indicator 2 Indicator $n$

\section{B. Principal component analysis}

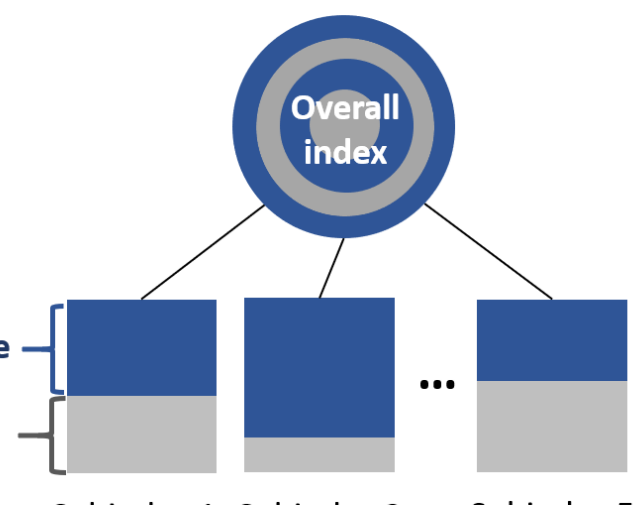

Subindex 1 Subindex $2 \quad$ Subindex 5

Source: SAS (2017). The authors revised the original diagrams.

Figure 1. Comparison of factor analysis and principal component analysis.

subcomponent indexes as possible in a single index (Figure 1.B) (Jolliffe, 2002) ${ }^{2}$. We use PCA for the overall determinant index because it is intended to represent the different features of each of the subcomponent indexes. This is unlike each subcomponent index, which is supposed to represent the common feature of its indicators ${ }^{3}$.

For each category of TFP determinants, we select indicators based on whether they measure an important characteristic, have been used in the literature, and have data available across countries and over time. In a few cases where most but not all information is available, we impute missing values based on income groups or trends, as explained at the end of this subsection.

Innovation. To construct a subcomponent index for innovation (Innov), we choose the following indicators: Public and private expenditure on R\&D as a percentage of GDP as an indicator of the effort to create new technologies (World Bank, 2017o); and the number of patent applications by residents and nonresidents and the number of scientific and technical journal articles as indicators of the outcome of R\&D activities (World Bank, 2017k,l,p).

Education. To construct a subcomponent index for education $(E d u c)$, we choose the following indicators: Government expenditure on education as percentage of GDP as an indicator of public investment in foundational human capital (World Bank, 2017f); the shares of population aged

\footnotetext{
${ }^{2}$ We select a factor, or a principal component in the case of PCA, with an eigenvalue higher than 1 . In our analysis, there is only one factor for each subcomponent index and one principal component for the overall index with an eigenvalue higher than 1.

${ }^{3}$ In order for the variables to enter factor/principal component analysis, they must have a sufficiently high degree of commonality. We run the Kaiser-Meyer-Olkin test to examine whether the indicators have enough common variance. A test value below the critical value of 0.5 means that an indicator or a group of indicators are unacceptable. For factor analysis, the test results show that the selection of indicators as a group is acceptable with a value of 0.60 for innovation, 0.69 for education, 0.63 for market efficiency, 0.83 for infrastructure, and 0.92 for institutions. The test results for individual indicators in each category are also above the critical value. For principal component analysis, used to construct the overall index, the test result is 0.88 for the group of the subcomponent indexes, and also above the critical value for each subcomponent index.
} 
25 and over with completed secondary education and with completed tertiary education (Barro and Lee, 2013) as indicators of educational attainment among workers; and a standardized international test score - a single average of scores in math, science, and reading on the Programme for International Student Assessment (PISA) - as an indicator of educational quality (OECD, 2016a,b,c).

Market Efficiency. To construct a subcomponent index for market efficiency (Effi), we classify markets into output, financial, and labor markets. We select the World Bank Doing Business scores as an indicator of output market efficiency, which measure the regulatory environment in terms of ease for firms to start a business, trade across borders, register property, get credit, and the like (World Bank, 2017a). We choose the International Monetary Fund (IMF) Financial Development Index as an indicator of financial market efficiency, which measures the level of financial development by including the size and liquidity of financial markets, ease for individuals and firms to access financial services, and the ability of financial institutions to provide services at low costs with sustainable revenues (Svirydzenka, 2016). As indicators of labor market efficiency, we construct an composite index, using factor analysis, consisting of minimum wage ( $\%$ of value added per worker), severance pay for redundancy dismissals (weeks of salary), and the share of women in wage employment in the nonagricultural sector from World Bank databases (World Bank, 2017h,q).

Infrastructure. For a subcomponent index for infrastructure (Infra), we select fixed-telephone and mobile subscriptions (per 100 people) (World Bank, 2017c,i); the length of paved roads (km per 100 people) (International Road Federation, 2017a,b); electricity production (kw per 100 people) (OECD/IEA, 2017); and access to an improved water source and improved sanitation facilities ( $\%$ of population) (WHO/UNICEF, 2017a,b).

Institutions. To construct a subcomponent index for institutions (Inst), we select the World Bank Worldwide Governance Indicators. These include measures of voice and accountability (citizens' participation in selecting their government and freedom of expression); control of corruption (the extent to which public power is exercised for personal gain); government effectiveness (the quality of public services and policy formulation and implementation); political stability (the absence of politically motivated conflict); regulatory quality (the ability of government to formulate and implement regulations that promote private sector development); and the rule of law (the extent to which citizens have confidence in and abide by laws) (Kaufmann and Kraay, 2017).

When necessary, we impute missing values of the selected indicators to balance sample sizes across countries and maximize the number of countries in the sample. We use different methods depending on the number of available data and the characteristics of the indicators. For a country that has data for more than 10 out of 30 years (1985-2014) for an indicator, we project a linear trend over years to impute missing values. For a country that has data for less than 10 years, we replace missing values with a median value corresponding to the country's income and regional group. We apply a different method for PISA scores because available data are less than for 10 years for all countries. Considering a statistically significant correlation of 0.66 ( $\mathrm{p}$-value $<0.01$ ) between PISA scores and log-transformed GDP per capita lagged by five years, we regress PISA scores on the lagged log-transformed GDP per capita, controlling for time-effects in a cross- 
country, time-series pooled data set ${ }^{4}$. Then, we replace missing PISA scores with a median score by the country's income and regional group using scores predicted by the regression model. For minimum wage and severance pay, we apply the oldest available data (2014) to the period before 2014, because available data (2014-2017) are insufficient to evaluate a time trend and their values are difficult to impute based on the country's income and regional group.

\subsection{Relationship Between the Main Determinants of TFP and TFP Growth}

The Relative Contribution of the Main Determinants to the Variance of Total Factor Productivity Growth

To help assess the relative contribution of the five main determinants to TFP growth, we decompose the variance of the TFP growth rate (over $t-5$ to $t$ ) to that explained by each subcomponent index (at $t-5$ ), controlling for an initial TFP level (at $t-5$ ) and time-effects for 98 countries. A review of measures of relative importance based on variance decomposition by Grömping (2007) suggests that the "dominance analysis" approach (Budescu, 1993; Azen and Budescu, 2003) is a reasonable method, mainly to deal with the presence of covariance across individual determinants. This approach calculates the contribution of a subcomponent index as the increase in the explained variance when the subcomponent index is added to each subset of other subcomponent indexes. For instance, the contribution of the innovation index $\left(\right.$ innov $\left._{c, t}\right)$ is computed by averaging ${ }^{5}$ the increase in the explained variance of TFP growth rate when innov $_{c, t}$ is added to each of the 16 additive subsets of other four subcomponent indexes $\left(\{\},.\left\{e d u c_{c, t}\right\}, \ldots,\left\{\right.\right.$ inst $\left._{c, t}\right\},\left\{e d u c_{c, t}\right.$, effi $\left.i_{c, t}\right\}, \ldots\left\{\right.$ infra $_{c, t}$, inst $\left._{c, t}\right\},\left\{e d u c_{c, t}\right.$, eff $i_{c, t}$, infra $\left._{c, t}\right\}$, $\ldots,\left\{\right.$ educ $_{c, t}$, infra $_{c, t}$, inst $\left._{c, t}\right\},\left\{\right.$ educ $_{c, t}$, eff $i_{c, t}$, infra $_{c, t}$, inst $\left.\left._{c, t}\right\}\right)$.

The Relationship Between the Overall Determinant Index and Total Factor Productivity Growth

To quantify the relationship between the overall determinant index and TFP growth, we build a regression model in which TFP growth rate is a function of a time-lagged overall determinant index and a time-lagged TFP level with country- and time-effects (equation (2)). We rescale the overall index to be from 1, representing the lowest performance, to 100, the best across countries over the last three decades. For this purpose, we use the following linear transformation, (original index for country $c$ and time $t$ - lowest index) / (highest index - lowest index $) *(100-1)+1$. According to preliminary analysis, the relationship between the index and TFP growth declines as the index increases; to allow for this non-linearity, we log-transform the rescaled index. We apply a time lag of five years to reduce the likelihood of endogeneity as reverse causation. This also allows us to smooth the TFP growth series, considering that, at shorter frequencies, it may be driven by business-cycle fluctuations (see Beck et al., 2000; Giavazzi and Tabellini, 2005).

We run different regressions for comparison and robustness check: without country-effects and with random country-effects, and with different time lags of three and seven years. We use

\footnotetext{
${ }^{4} P I S A_{c, t}=\beta_{0}+\beta_{1} \ln (G D P \text { per capita })_{c, t-5}+\delta_{t}, c:$ country $(1, \ldots, 76), t:$ year $(2003 / 06 / 09 / 12 / 15) ; \beta_{0}=187.1^{*}$, $\beta_{1}=28.7^{* * *}{ }^{* * *}: \mathrm{p}$-value $\left.<0.01\right), R^{2}=0.444$.

${ }^{5}$ Two-step average: First, the additional contributions are averaged within a group of the same size of the subset, then the results from the first step are averaged across groups with different sizes of the subset.
} 
(White-Huber) robust standard errors. After fitting the models to the sample, we incorporate the results into the Long-Term Growth Model (Loayza and Pennings, 2018) in order to run country and region simulations on the potential path of TFP growth.

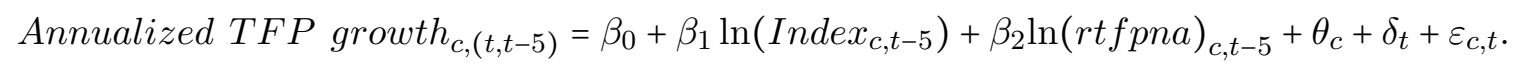

Annualized TFP growt $h_{c,(t, t-5)}$ : annualized TFP growth over $t-5$ and $t$.

Index $x_{c, t-5}$ : overall determinant index, rescaled 1 to 100.

rtfpna $_{c, t-5}$ : TFP level $(2011=1)$.

$\theta_{c}$ : country effect.

$\delta_{t}$ : time effect.

$\varepsilon_{c, t}:$ residuals.

\section{Results}

\subsection{Total Factor Productivity}

Figure 2 shows that for 21 OECD countries, the median and (simple) average annual TFP growth rates are positive during 1985-2004 and decrease below zero for 2005-14; whereas for 93 developing countries, they are negative during 1985-94 and increase above zero for 1995-2014. Figure 3 shows median and (simple) average annual TFP growth rates for developing countries by region. For East Asia and Pacific, TFP growth rates are positive for the last three decades between 0.4 percent and 1.3 percent. For Europe and Central Asia, TFP growth rates are negative for 1985-94, increase in the next decade to above 2 percent, and decrease to around 1.2 percent for the last decade. For Latin America and Caribbean, TFP growth rates increase from around -0.4 percent during 1985-2004 to around 0.5 percent for 2005-14. For Middle East and North Africa, TFP growth rates increase from near zero or negative in 1985-94 to around 0.5 percent in the next decade and decrease to below -0.5 percent in the last decade. For South Asia, TFP growth rates are positive for the last three decades, ranging between 0.3 percent and 1.5 percent. For Sub-Saharan Africa, TFP growth rates increase from around -1 in 1985-1994 to +1 in the two decades spanning 1994-2014. Figure 4 shows regional average TFP growth rates weighted by total GDP (World Bank, 2017d), the trend of which is similar to that of the unweighted average TFP growth rates in Figure 3.

\subsection{Main Determinant Indexes}

Figure 5 shows the median of the subcomponent indexes representing the main categories of TFP determinants, as well as the median of the overall index, for all, 21 OECD, and 115 developing countries by decade. All the median indexes are lower for the developing countries as compared to the OECD countries. A noticeable difference is that the innovation index stays at the lowest level for the developing countries, whereas it increases in the OECD group over time. For both groups, the subcomponent indexes of education, market efficiency, and infrastructure increase over decades, whereas that of institutions stays at the same level. 


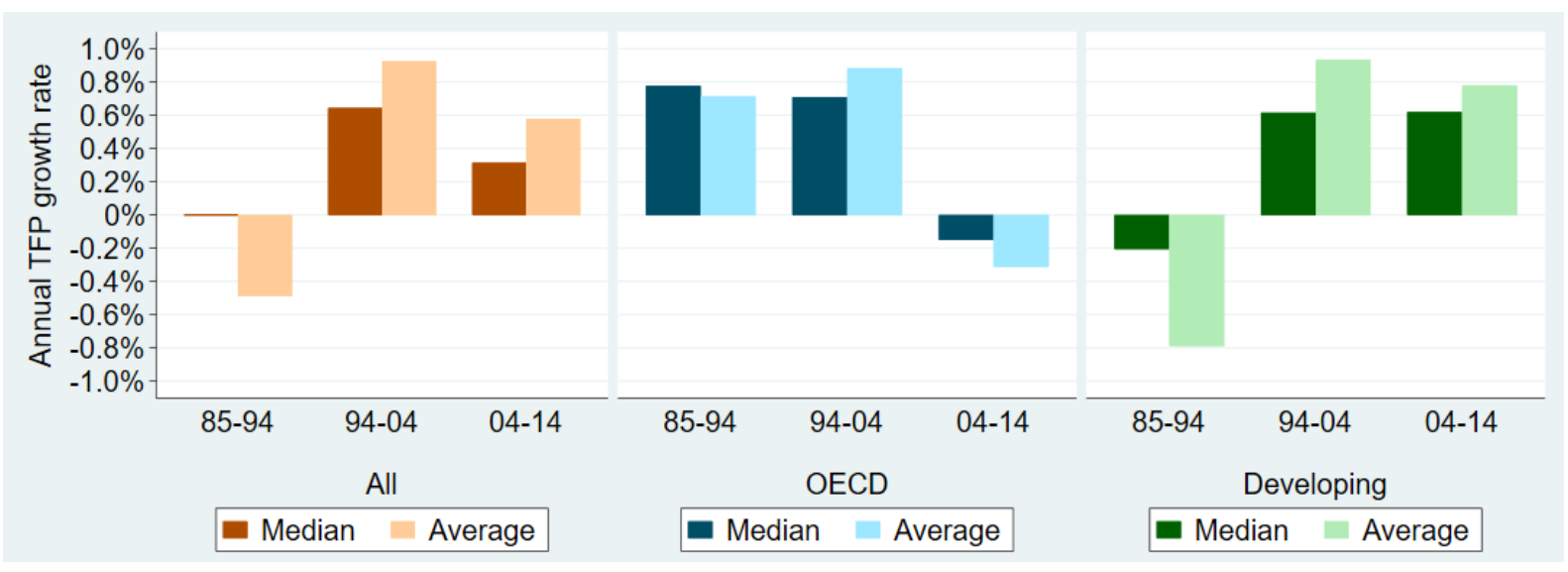

Source: Authors' calculation, using PWT 9.0 data complemented, in a few cases, with GTAP data.

Note: The OECD group includes high-income countries that have been members of OECD for more than 40 years; the former Soviet Union countries are excluded in the period 1985-94 considering their independence in the early 1990s.

Figure 2. Annual TFP growth rate for all, OECD, and developing countries, median and simple average by decade.

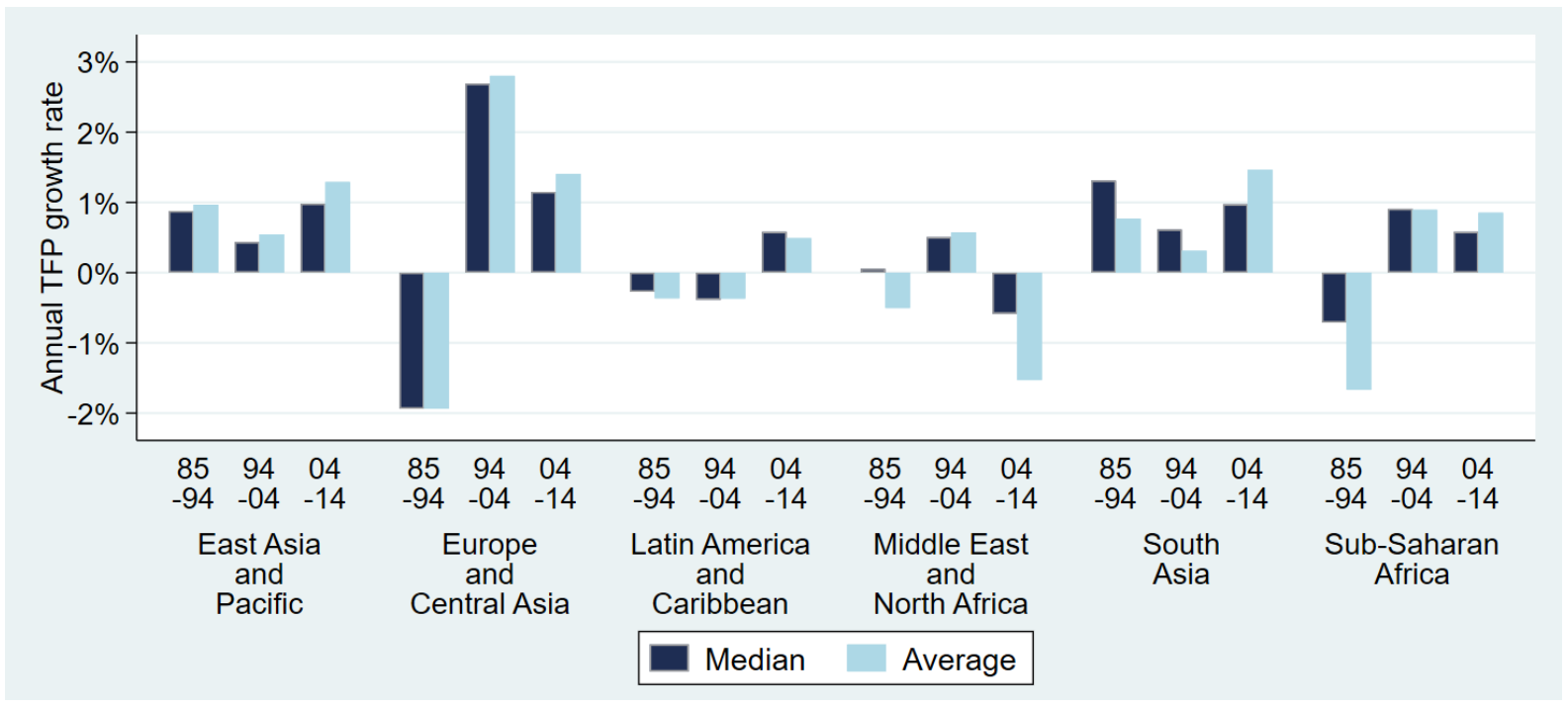

Source: Authors' calculation, using PWT 9.0 data complemented, in a few cases, with GTAP data.

Note: The former Soviet Union countries are excluded in the period 1985-94 considering their independence in the early 1990s.

Figure 3. Annual TFP growth rate for developing countries, median and simple average by region and decade.

For the innovation subcomponent index, the indicators carry similar weights (equation (3)). Factor analysis shows that the subcomponent index accounts for 76 percent of the total variance of the indicators, accounting for 90 percent of the variance of $\mathrm{R} \& \mathrm{D}$ expenditure $(R \& D), 61$ percent of that of the number of patents (patent), and 79 percent of that of the number of journal articles (article).

$$
\text { Innov }_{c, t}=0.41 \cdot z\left(R \& D_{c, t}\right)+0.34 \cdot z\left(\text { patent }_{c, t}\right)+0.39 \cdot z\left(\text { article }_{c, t}\right),
$$




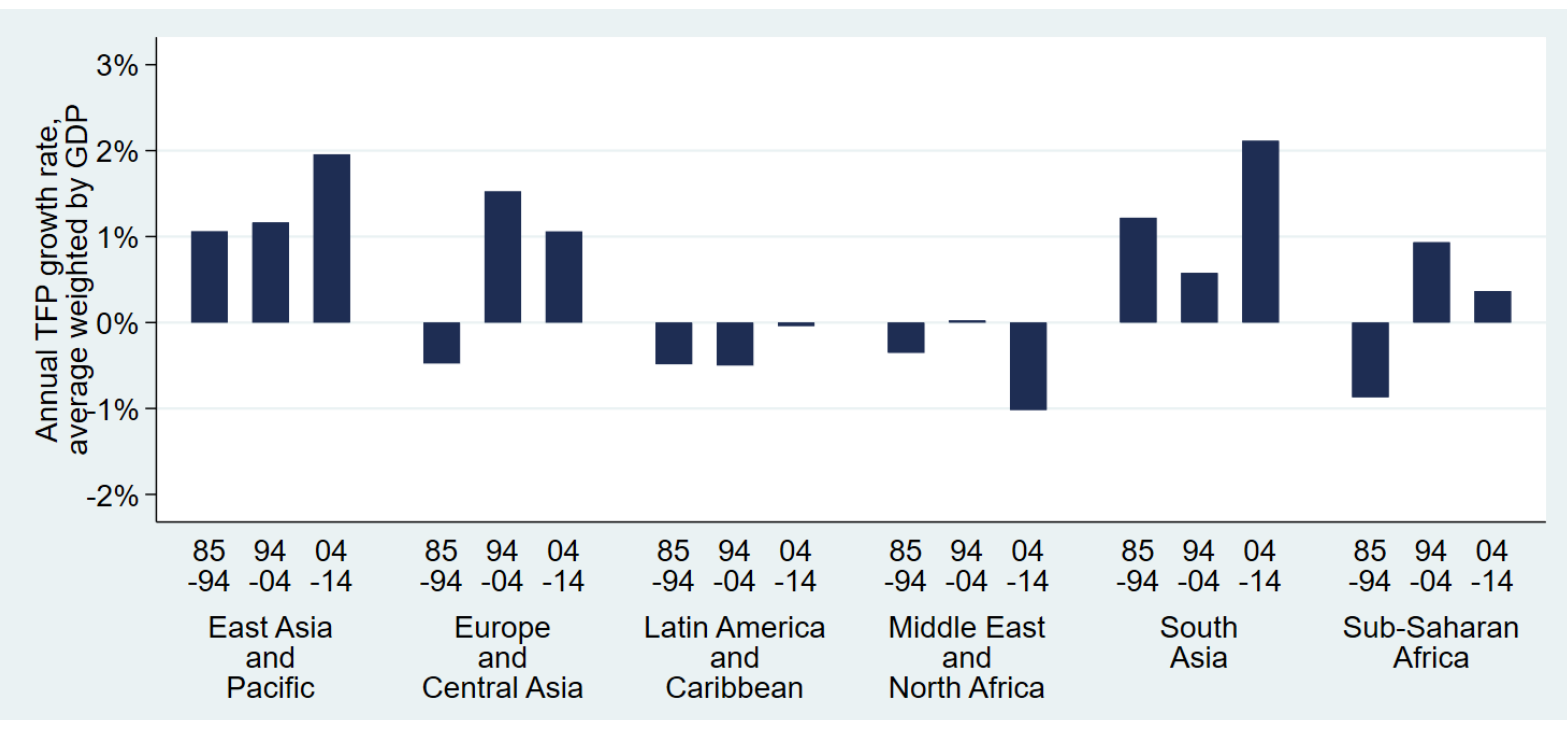

Source: Authors' calculation, using PWT 9.0 data complemented, in a few cases, with GTAP data.

Note: The former Soviet Union countries are excluded in the period 1985-94 considering their independence in the early 1990s.

Figure 4. Annual TFP growth rate for developing countries, average weighted by real GDP by region and decade.

where $z(X)$ is standardized $X, \frac{X-\text { mean }(X)}{\text { standard deviation }(X)}$.

For the education subcomponent index, the performance-related indicators have similar weights and the education-expenditure indicator has a lower weight (equation (4)). Factor analysis indicates that the subcomponent index accounts for 55 percent of the total variance in the indicators, accounting for 20 percent of the variance of education expenditure (eduexp), 63 percent of that of secondary attainment (secondary), 75 percent of that of tertiary attainment, and 63 percent of that of PISA scores (pisa). The lower weight and the smaller contribution of the education expenditure indicator to the common variance shows that this indicator has a low correlation with the outcome indicators.

$$
E d u_{c, t}=0.20 \cdot z\left(\text { eduexp }_{c, t}\right)+0.36 \cdot z\left(\text { secondary }_{c, t}\right)+0.39 \cdot z\left(\text { pisa }_{c, t}\right)+0.36 \cdot z\left(\text { tertiary }_{c, t}\right) .
$$

For the market-efficiency subcomponent index, the indicators are combined with similar weights (in absolute terms) (equation (5)). Factor analysis shows that the subcomponent index accounts for 69 percent of the total variance in the three indicators, accounting for 79 percent of the variance of Doing Business scores (business), 78 percent of that of Financial Development Index (financial), and 49 percent of the labor index (labor). In turn, factor analysis shows that the labor index accounts for 48 percent of the total variance of the minimum wage (minwage), 53 percent of that of the severance pay (severance), and 52 percent of that of the share of women employed in the nonagricultural sector (women).

$$
\operatorname{Effi}_{c, t}=0.43 \cdot z\left(\text { business }_{c, t}\right)+0.43 \cdot z\left(\text { financial }_{c, t}\right)-0.34 \cdot z\left(\text { labor }_{c, t}\right),
$$




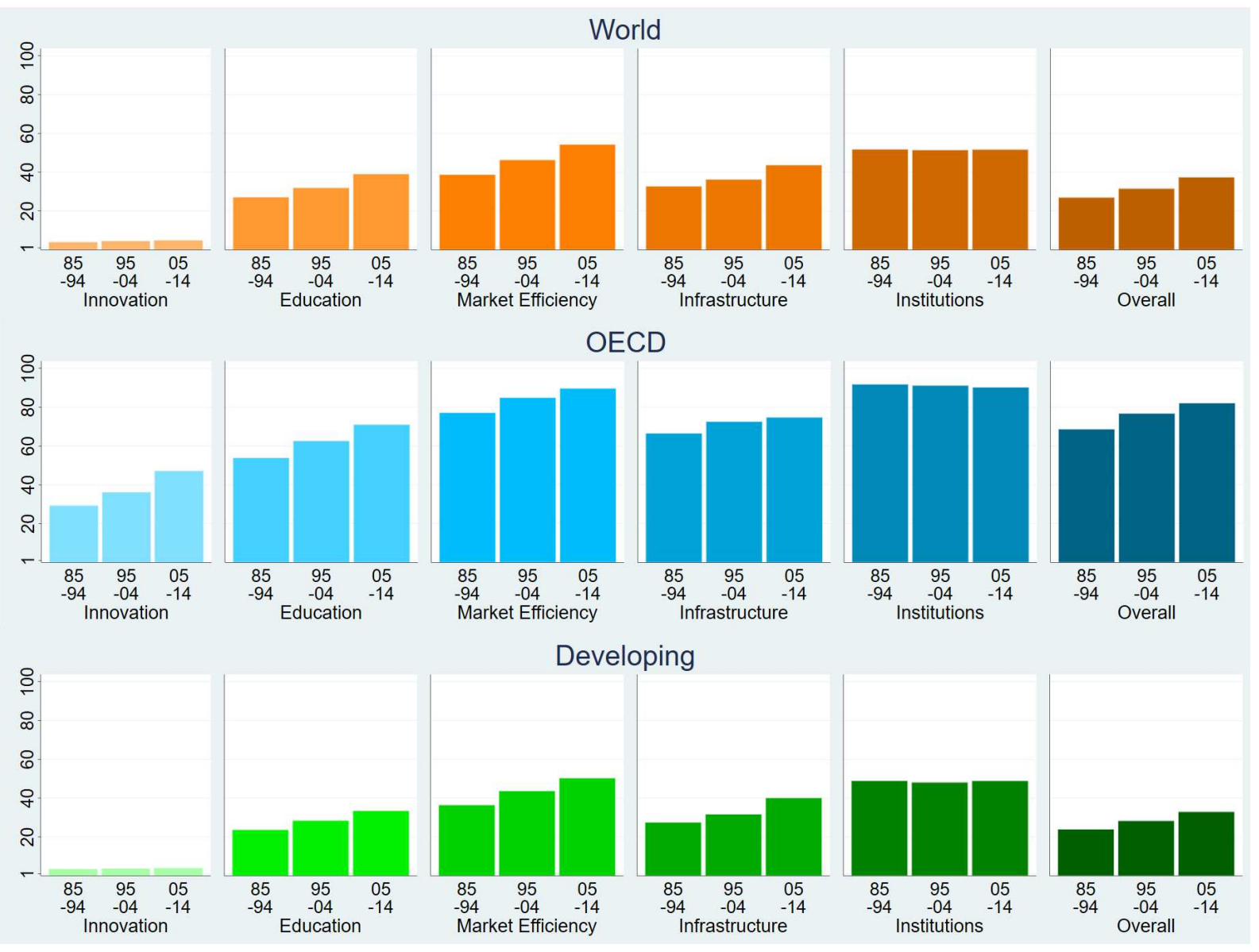

Source: Authors' calculation.

Note: The OECD group includes high-income countries that have been members of OECD for more than 40 years; the indexes are rescaled to range from 1, the lowest performance, to 100, the best among all countries over the three decades.

Figure 5. Median of subcomponent and overall determinant indexes for all, OECD, and developing countries by decade.

where

$$
\text { labor }_{c, t}=0.45 \cdot z\left(\text { minwage }_{c, t}\right)+0.47 \cdot z\left(\text { severance }_{c, t}\right)-0.47 \cdot z\left(\text { women }_{c, t}\right)
$$

For the infrastructure subcomponent index, all indicators except for mobile subscription have similar weights (equation (6)). Factor analysis shows that the subcomponent index accounts for 65 percent of the total variance in its indicators, accounting for 78 percent of the variance of the number of telephone subscription (tele), 28 percent of that of mobile subscription (mobile), 64 percent of that of paved road (road), 67 percent of that of electricity production (elec), 70 percent of that of access to improved water source (water), and 76 percent of that of access to improved sanitation facilities (sanit).

$$
\begin{aligned}
\text { Infra }_{c, t}=0.23 \cdot z\left(\text { tele }_{c, t}\right)+0.14 \cdot z\left(\text { mobile }_{c, t}\right) & +0.21 \cdot z\left(\operatorname{road}_{c, t}\right)+0.21 \cdot z\left(\operatorname{elec}_{(}(c, t)\right) \\
& +0.22 \cdot z\left(\text { water }_{c, t}\right)+0.23 \cdot z\left(\operatorname{sanit}_{c, t}\right) .
\end{aligned}
$$


The institutions subcomponent index consists of the six indicators with similar weights (equation (7)). The subcomponent index accounts for 87 percent of the total variance in its indicators, accounting for 83 percent of the variance of voice and accountability $(\mathrm{va}), 90$ percent of that of the control of corruption $(c c), 93$ percent of that of government effectiveness $(g e), 71$ percent of that of political stability $(\mathrm{ps}), 89$ percent of that of regulatory quality $(\mathrm{rq})$, and 94 percent of that of the rule of law $(r l)$.

$$
\text { Inst }_{c, t}=0.18 \cdot z\left(v a_{c, t}\right)+0.19 \cdot z\left(c c_{c, t}\right)+0.19 \cdot z\left(g e_{c, t}\right)+0.16 \cdot z\left(p s_{c, t}\right)+0.18 \cdot z\left(r q_{c, t}\right)+0.19 \cdot z\left(r l_{c, t}\right) .
$$

The overall determinant index is a linear combination of the (standardized) five subcomponent indexes with similar weights (equation (8)). The overall index, obtained through principal component analysis, represents the innovation index with a correlation of 0.88 ; the education index, 0.90; the market-efficiency index, 0.94; the infrastructure index, 0.94; and the institutions index, 0.87 .

$$
\begin{aligned}
\operatorname{Index}_{c, t}=0.43 \cdot z\left(\operatorname{Innov}_{c, t}\right)+0.44 \cdot z\left(E d u_{c, t}\right)+0.46 \cdot z\left(\text { Effi }_{c, t}\right) & +0.47 \cdot z\left(\operatorname{Infra}_{c, t}\right) \\
& +0.43 \cdot z\left(\text { Inst }_{c, t}\right) .
\end{aligned}
$$

Appendix C shows the average values of the individual indicators, as well as the subcomponent and overall indexes, over 1985-2014 by income and regional group.

\subsection{Relationship Between the Main Determinants of TFP and TFP Growth \\ The Relative Contribution of the Main Determinants to the Variance of Total Factor Produc- tivity Growth}

Figure 6 shows the decomposition of the total explained variance of the TFP growth rate corresponding to each of the main TFP determinants by decade for all, OECD, and developing countries (controlling for the five-year-lagged TFP level and time-effects). For the OECD countries, a notable trend is that the contribution of the market-efficiency index increases and accounts for 45 percent of the explained variance of TFP growth in the last decade; whereas that of infrastructure decreases and explains the least. For developing countries, in 1985-94 the TFP determinant with the highest explanatory power of TFP growth variance is institutions; however, its contribution decreases afterward. The contribution of education increases over the two decades and accounts for almost 50 percent of the explained variance of TFP growth in the last decade.

The variance decomposition analysis helps understand what drives the differences across countries regarding TFP growth. It does not, however, indicate what the most important or relevant drivers of TFP growth are for specific countries. For this, we would need to know the countryspecific gaps in each determinant of TFP. We turn to this issue in section 5, on simulations and scenario analysis. Before, however, we need to obtain a reasonable estimate of the effect of the overall index on TFP growth, which we attempt next. 


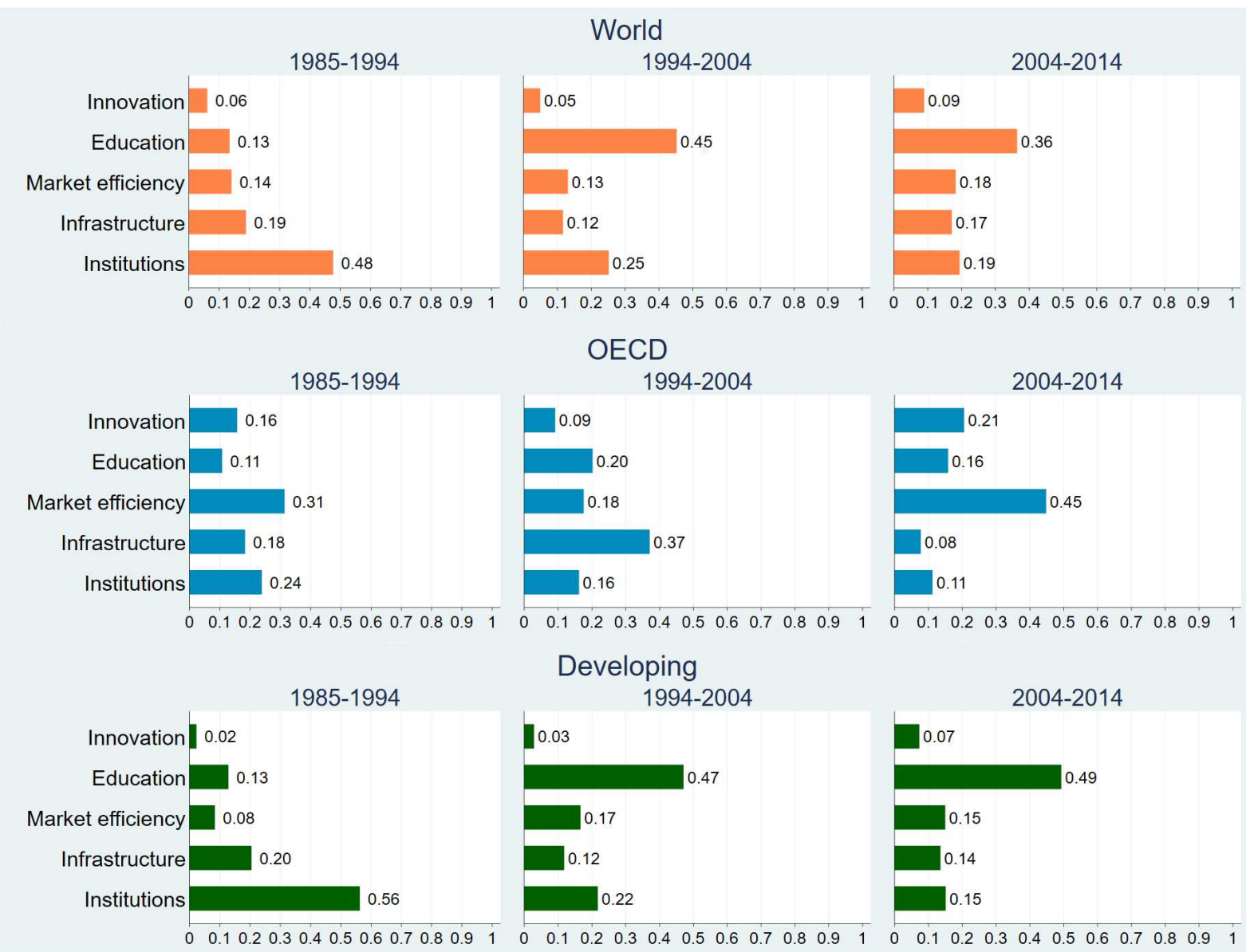

Source: Authors' calculation.

Note: The OECD group includes high-income countries that have been members of OECD for more than 40 years.

Figure 6. Variance decomposition of TFP growth rate corresponding to the determinant subcomponent indexes by decade for all, OECD, and developing countries, controlling for initial TFP and time effects.

The Relationship Between the Overall Determinant Index and Total Factor Productivity Growth

Table 1 shows the regression results for equation (2) in which the TFP growth rate is a function of the lagged overall determinant index and the lagged TFP level, along with countryand time-effects. We do not attempt a regression with the five subcomponent indexes as individual regressors because they are very highly correlated, and their estimated marginal effects would be contaminated by multicollinearity.

As Table 1 shows, the lagged overall index and the lagged TFP level are statistically significant in all regressions, with no, random, and fixed country-specific effects, respectively. Based on the Hausman test, which suggests bias estimation if correlated country-specific effects are not considered, we choose to focus on the regression with fixed (correlated, not random) countryspecific effects.

In the fixed effects model, an increase of the lagged overall determinant index by 1 percent is 
Table 1

Linear regression results

\begin{tabular}{|c|c|c|c|}
\hline \multicolumn{4}{|c|}{$\begin{array}{l}\text { Dependent variable: Annualized TFP } \text { growth }_{c,(t-5, t)} \\
\text { Number of observations: } 477 \\
\text { Number of groups (countries): } 98\end{array}$} \\
\hline & \multicolumn{3}{|c|}{ Country effects: } \\
\hline & None & Random & Fixed \\
\hline Regressors (below): & Coefficient (SE) & Coefficient (SE) & Coefficient (SE) \\
\hline $\ln \left(\operatorname{Index}_{c, t-5}\right)$ & $0.004(0.0011)^{* * *}$ & $0.004(0.0011)^{* * *}$ & $0.050(0.0183)^{* * *}$ \\
\hline $\ln (T F P \text { level })_{c, t-5}$ & $-0.082(0.0052)^{* * *}$ & $-0.082(0.0052)^{* * *}$ & $-0.099(0.0151)^{* * *}$ \\
\hline Year 1999 & $-0.001(0.0036)$ & $-0.001(0.0036)$ & $-0.006(0.0034)$ \\
\hline Year 2004 & $0.012(0.0031)^{* * *}$ & $0.012(0.0031)^{* * *}$ & $0.004(0.0034)$ \\
\hline Year 2009 & $0.010(0.0030)^{* * *}$ & $0.010(0.0030)^{* * *}$ & $-0.001(0.0045)$ \\
\hline $\begin{array}{l}\text { Year } 2014 \\
\text { (Reference year: 1993) }\end{array}$ & $0.010(0.0034)^{* * *}$ & $0.010(0.0034)^{* * *}$ & $-0.004(0.0063)$ \\
\hline $\begin{array}{l}\text { Constant } \\
R^{2}:\end{array}$ & $-0.021(0.0055)^{* *}$ & $-0.021(0.0055)^{* * *}$ & $-0.180(0.0636)^{* * *}$ \\
\hline Within & Not applicable & 0.2784 & 0.3048 \\
\hline Between & Not applicable & 0.8573 & 0.2749 \\
\hline Overall & 0.4022 & 0.4022 & 0.1586 \\
\hline
\end{tabular}

$\mathrm{SE}=$ Standard error; $*$ : significant at $10 \%$;*: significant at $5 \%$; **: significant at $1 \%$ level.

Note: Hausman test rejects the null hypothesis $\left(H_{0}\right.$ : coefficients are consistent under both random and fixed effects) with Chi-square 22.90 and p-value less than 0.01 . The $R^{2}$ in the case of the fixed-effects estimator does not consider the explanatory contribution of the country-specific constants (which is why its overall value is lower than in the other cases). In the regression with no country effects, we use clustered robust (White-Huber) variance estimation, treating countries as clusters.

associated with an increase of the annual TFP growth rate by 0.05 percent, after controlling for the lagged TFP level and country and time effects. Suggesting convergence, an increase of lagged TFP by 1 percent is associated with a decrease of annual TFP growth rate by 0.10 percent, holding other variables constant. This implies that countries with a higher level of TFP need to increase the determinant index more than those with a lower level of TFP to achieve the same amount of increase in TFP growth. These results are robust in terms of signs and significance when we use different lags of three and seven years (see appendix D). They are also robust when we use the WDI-based data in the construction of TFP levels and growth rates (see appendix $\mathrm{E})$.

\section{Simulations and Scenario Analysis}

\subsection{Groups of Countries by Geographic Region and Income Level}

For illustration purposes, in this section we simulate the change in TFP growth rate for 78 low- and middle-income developing countries (that is, countries with GDP per capita in 2014 lower than $\$ 12,056$, constant USD 2010). We present the simulation results in averages by region or income group. More generally, the Long-Term Growth Model (LTGM) toolkit can be used to generate country-specific projections for TFP growth for a much larger set of countries. This 
allows of the LTGM users to replace the assumption of an exogeneous path for TFP growth by one that is based on improvements in innovation, education, market efficiency, infrastructure, and institutions, feeding into the overall determinant index.

We provide four scenarios below. They present different ways and extents of improving the TFP determinant index, to regional or world benchmarks (or leaders). We use the fixed-effect regression results to relate changes in TFP growth to changes in the overall determinant index. The corresponding increase in TFP growth depends directly on the speed of progress in the country's TFP determinants and inversely on the extent of previous TFP improvement. Thus, countries with a larger gap on their TFP determinant index with respect to the benchmark could experience a larger increase in TFP growth if they made reforms to approach the leader. In turn, countries with a high increase in TFP growth would slow down their subsequent growth in TFP. The positive impact of improvements in the TFP determinant index and the negative impact of previous TFP growth create an interesting, nonlinear path of projected TFP growth: In most cases, TFP growth follows a convex path that increases at a decreasing rate, reaches a maximum, and then decreases or stabilizes. Since in the simulations the reforms to improve TFP determinants do not occur immediately but gradually over time (in two scenarios, to imitate the actual trajectory of benchmark countries in the last three decades), the projected TFP growth has an additional source of convexity, as the growth rate of the TFP determinant index tends to decline over time.

Scenario I: Improving to the highest TFP determinant index in the region.

Scenario I assumes that a country improves its overall determinant index to the highest index among all developing (non-OECD) countries in its region. We assume a country's overall determinant index increases at constant increments from the initial value (in 2014) to the current index of its benchmark country, shown in Table 2, over 15 years and keeps increasing with the same slope afterward.

Figure 7 shows the average TFP growth rate under scenario I. For East Asia and Pacific, starting from the highest historical average TFP growth rate over 1985-2014 among all regions, the average TFP growth rate is expected to increase to 2.5 percent over the next 12 years and then gradually decrease. For Sub-Saharan Africa, the average TFP growth is expected to increase to 1.9 percent over the next 15 years, which is the sharpest increase from the corresponding historical TFP growth rate among all regions. For Europe and Central Asia, Latin America and Caribbean, and Middle East and North Africa, the simulated average TFP growth rates are similar in that they increase to almost 1 percent in the next 23 years and decrease gradually. For South Asia, the average TFP growth rate stays in the range from 0.6 to 0.8 percent. Using regional benchmarks limits the possibility of progress in TFP growth because the regional leaders may not be very advanced themselves. Such is the case of India for South Asia.

Scenario II: Following the trajectory of the most improving TFP overall index in the region.

Scenario II assumes that a country replicates the trajectory, in terms of annual change, in the last three decades of the TFP overall determinant index corresponding to the regional benchmark

\section{PUCP}


Table 2

Benchmark countries with the highest overall determinant index as of 2014 by region.

\begin{tabular}{ll}
\hline Region & Country with the highest index as of 2014 \\
\hline East Asia and Pacific & Korea \\
Europe and Central Asia & Czech Republic \\
Latin America and Caribbean & Chile \\
Middle East and North Africa & United Arab Emirates \\
South Asia & India \\
Sub-Saharan Africa & South Africa \\
\hline
\end{tabular}

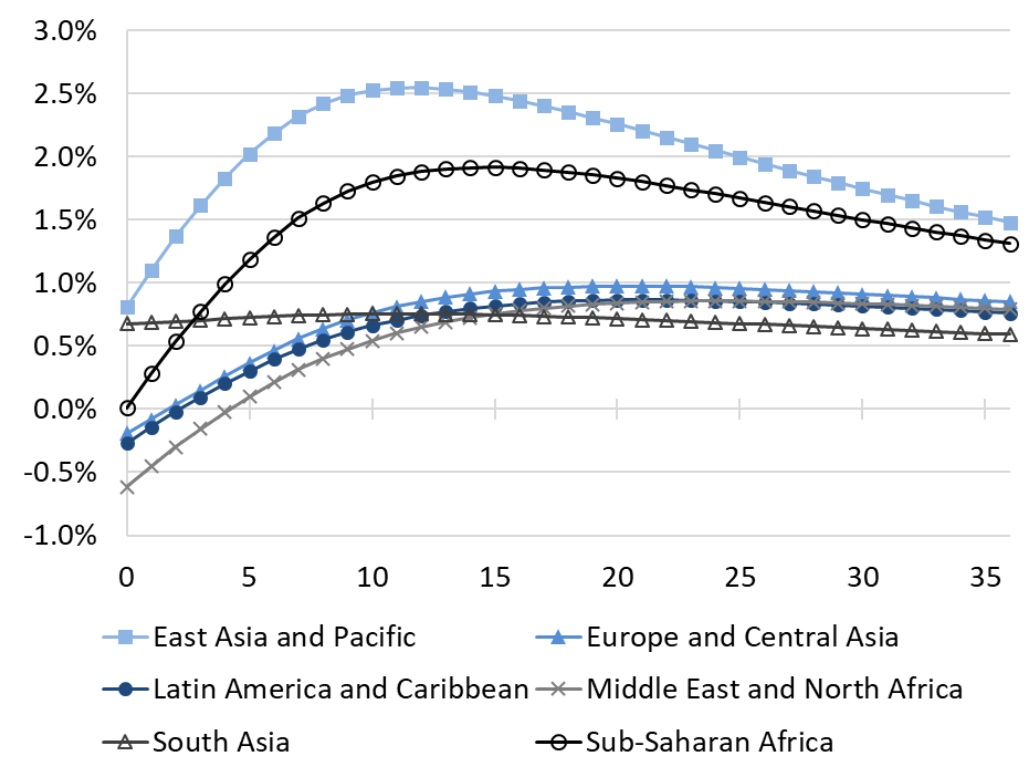

Figure 7. Simulated average TFP growth rate by region with the scenario that a country increases its overall determinant index to the highest index among developing countries in its region over 15 years.

country. The regional benchmark under scenario II is the country whose overall determinant index increases the most over 1985-2014 among all developing (non-OECD) countries in a given region (see Table 3).

We apply the annual change in the index of the benchmark country over 1985-2014 to that of all countries in the same region, starting from the initial index (2014) for the next 30 years and the average change over 2005-2014 for subsequent years.

Figure 8 shows the predicted average TFP growth rate under scenario II. For East Asia and Pacific, starting from the highest historical average TFP growth rate over 1985-2014, the average TFP growth rate is expected to increase to 1.7 percent over the next 15 years and then decrease. For Latin America and Caribbean and Sub-Saharan Africa, the simulated average TFP growth rate increases for more than 30 years to 0.9 and 1.2 percent, respectively. For Europe and Central Asia and Middle East and North Africa, the average TFP growth rate is expected to increase to 0.7 and 0.6 percent, respectively, over the next 20 years and decrease gradually. For South Asia, the simulated TFP growth rate stays in the range from 0.6 to 0.9 percent. 
Table 3

Benchmark countries with the most increase in the overall determinant index during 1985-2014 by region.

\begin{tabular}{ll}
\hline Region & Country with the most increase in the overall index during 1985-2014 \\
East Asia and Pacific & Korea \\
Europe and Central Asia & Czech Republic \\
Latin America and Caribbean & Colombia \\
Middle East and North Africa & United Arab Emirates \\
South Asia & India \\
Sub-Saharan Africa & Rwanda \\
\hline
\end{tabular}

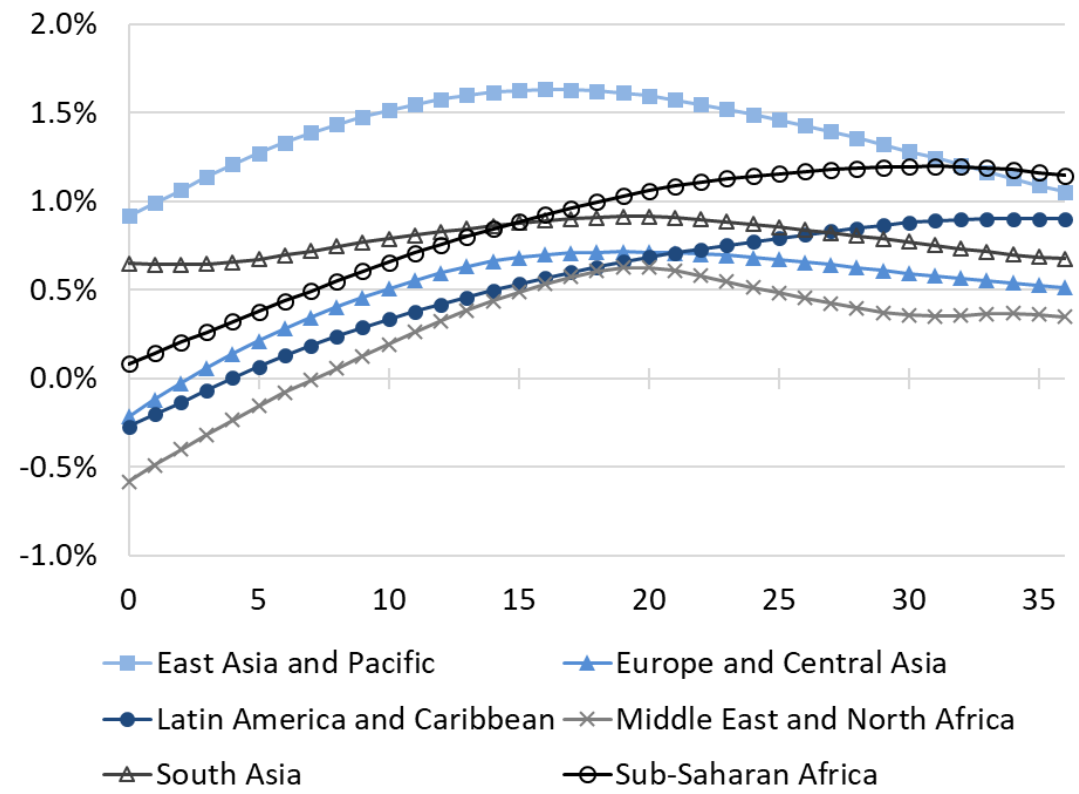

Figure 8. Simulated average TFP growth rate by region with the scenario that a country increases its overall determinant index to the highest index among developing countries in its region over 15 years.

Scenario III: Improving to the highest TFP determinant index among all developing countries.

Scenario III assumes that a developing country increases its overall determinant index to the highest index among all developing (non-OECD) countries as of 2014, which is that of the Republic of Korea. We assume a country's overall determinant index increases linearly from the value in 2014 to the index of Korea over 15 years and keeps increasing with the same slope afterward

Figure 9a shows that Sub-Saharan Africa, which has the largest gap with respect to the benchmark and has a relatively low TFP growth rate, is expected to have the highest increase from its historical average over 1985-2014 (initial value in the graph) and reach the highest average TFP growth rate of 3.4 percent in 11 years and then gradually decline. South Asia is expected to increase its TFP growth rate to 3.2 percent in 11 years and then decrease, similarly to Sub-Saharan Africa. East Asia and Pacific, with the highest historical average, is expected to 


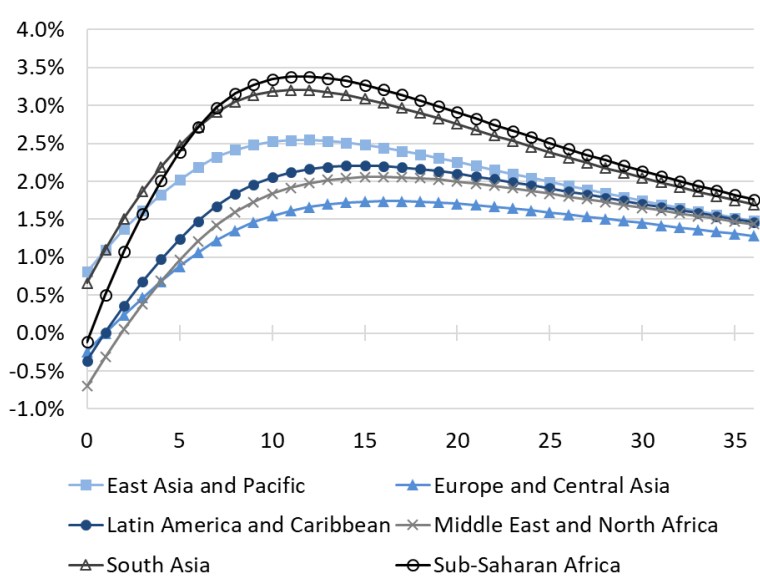

(a) Average TFP growth rate by region.

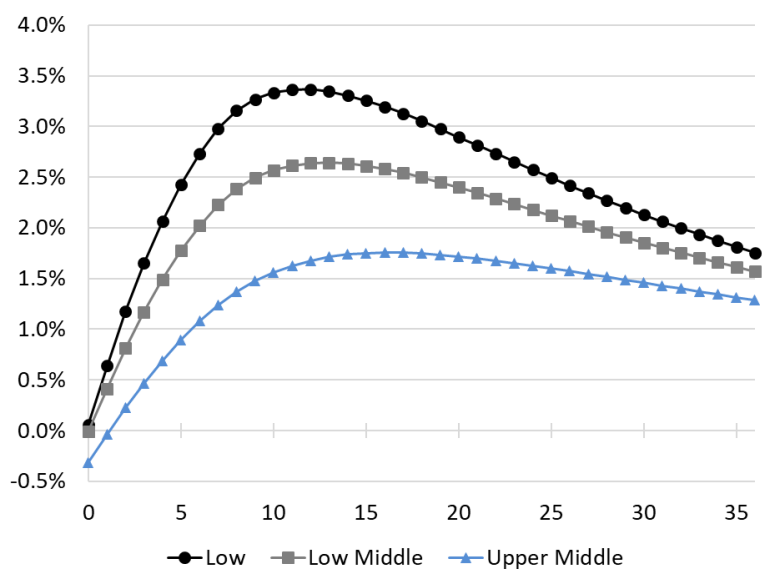

(b) Average TFP growth rate by income level ${ }^{a}$.

${ }^{a}$ Low: average GDP per capita over 1985-2014 (constant 2010 USD) $\geq \$ 995$; Low middle: $\$ 995-\$ 3,895$; Upper middle: $\$ 3,895-\$ 12,055$.

Figure 9. Simulated average TFP growth rate by region and income group with the scenario that a country increases its overall determinant index to the highest index among developing countries over 15 years.

increase its average TFP growth rate to 2.5 percent in 11 years; this is smallest gain from the historical average among all regions, reflecting its already high TFP growth in the past. Latin America and Caribbean and Middle East and North Africa, with negative historical average TFP growth, are expected to increase the average TFP growth rate to 2.2 and 2.1 percent, respectively, in 15 years. For Europe and Central Asia, with a negative historical growth, the average TFP growth rate increases to 1.7 percent in 16 years and then decreases.

Grouping countries by income level reveals interesting patterns. Figure $9 \mathrm{~b}$ shows that the low-income group is expected to increase its average TFP growth rate the most to 3.3 percent in 11 years, the low-middle income group to 2.6 percent in 12 years, and the upper-middle income group to 1.8 percent in 16 years. In all cases, TFP growth gradually declines after reaching a peak, approaching around 1.5 percent in 35 years. These results confirm the notion obtained from the regional results: a country, region, or group with a larger gap in the TFP determinant index with respect to the benchmark has more to gain and can experience a substantial increase in TFP growth if they conduct the corresponding reforms. For those with already high TFP growth and for those whose TFP growth rises sufficiently, subsequent TFP growth will tend to taper down.

Scenario IV: Following the trajectory of the most improving TFP overall index among all developing countries.

Scenario IV assumes that a country replicates a trajectory, in terms of annual change, of the world benchmark country. This is the country that has increased its overall determinant index the most over 1985-2014 among all developing (non-OECD) countries, which is Korea. We apply the annual change in the index of Korea over 1985-2014 to that of a country, starting from the 

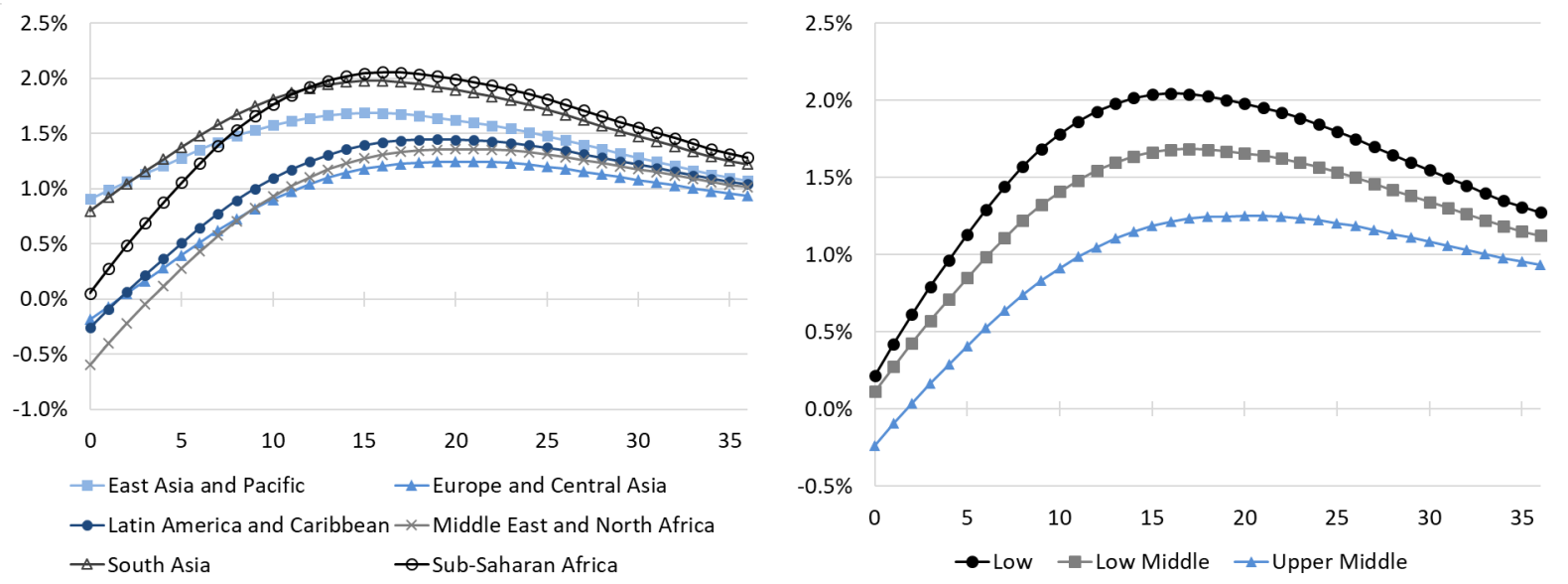

(a) Average TFP growth rate by region.

(b) Average TFP growth rate by income level ${ }^{a}$.

${ }^{a}$ Low: average GDP per capita over 1985 -2014 (constant 2010 USD) $\geq \$ 995$; Low middle: $\$ 995-\$ 3,895$;

Upper middle: $\$ 3,895-\$ 12,055$.

Figure 10. Simulated average TFP growth rate by region and income group with the scenario that a country replicates the trajectory of the overall index of Korea, which increases the index the most among all developing countries in the last three decades.

initial index (2014) for the next 30 years and the average change over 2005-2014 for subsequent years.

Figure 10a shows that Sub-Saharan Africa, with the largest gap with respect to the benchmark and a relatively low TFP growth rate, has the highest increase from its historical average over 1985-2014 (initial value in the graph) and reaches the highest average TFP growth rate of 2.1 percent in 16 years. South Asia is expected to increase its TFP growth rate to 2.0 percent in 16 years and decrease afterwards. East Asia and Pacific, with the highest historical average TFP growth, has the smallest projected increase in TFP growth, to 1.7 percent in 15 years. Latin America and Caribbean, Middle East and North Africa, and Europe and Central Asia, with negative historical average TFP growth, are expected to increase their TFP growth rates to 1.2 to 1.4 percent in $19-20$ years.

Figure 10b presents the results for income groups. It shows that the low-income group is expected to increase its average TFP growth rate the most to 2.0 percent in 16 years, the lowmiddle income group to 1.7 percent in 17 years, and the upper-middle income group to 1.2 percent in 20 years. The results in Figure 10 confirm the insight that countries, regions, or groups with a larger gap with respect to the benchmark, such as Sub-Saharan Africa, have more to gain in terms of future TFP growth, and those with higher TFP growth, for example, East Asia and Pacific, have a slower subsequent TFP growth.

\subsection{Peru: Country-Specific Illustration}

As mentioned before, the productivity component of the LTGM toolkit allows for a multitude of scenarios on the future path of TFP growth for individual countries. In this paper, as an 

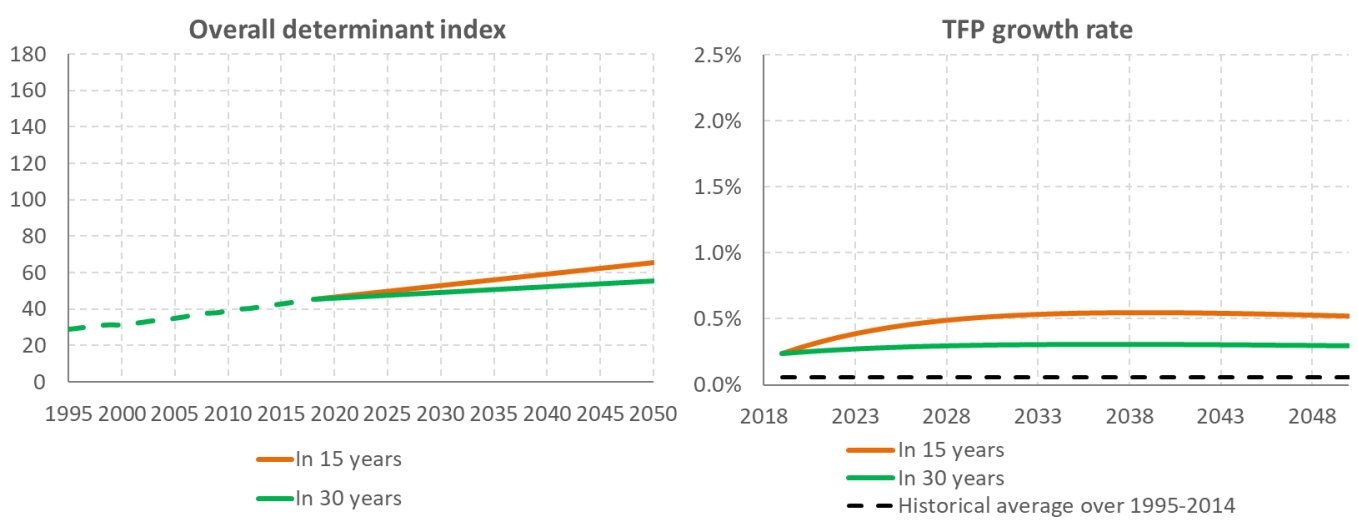

(a) The overall index increases to the highest index in Latin America (Chile) in 15 or 30 years.
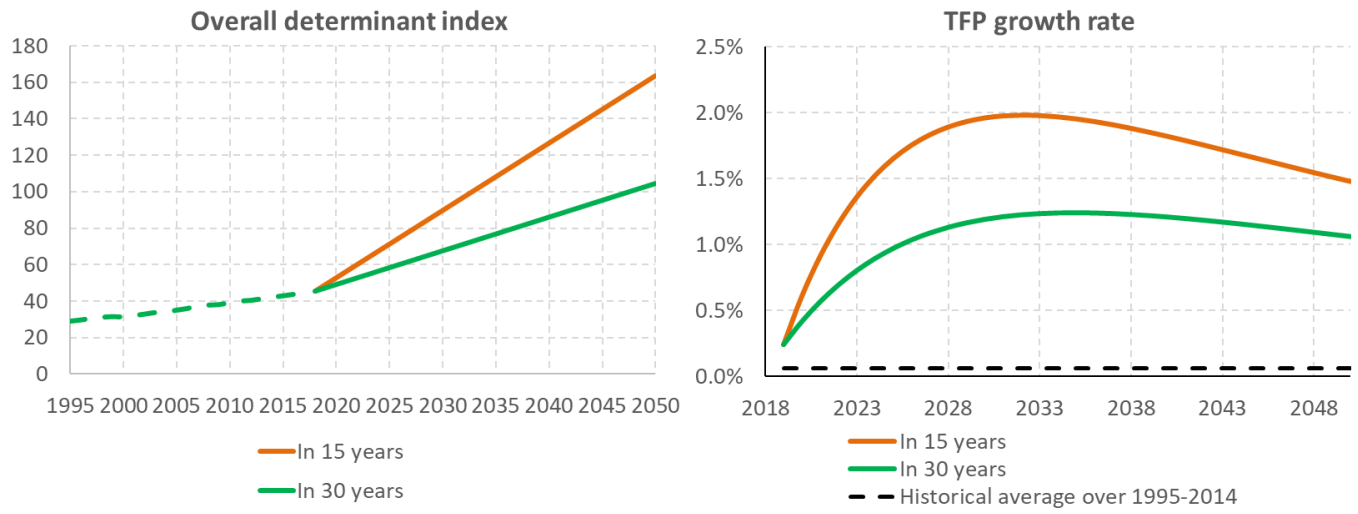

(b) The overall index increases to the highest index among all developing countries (Korea) in 15 or 30 years.
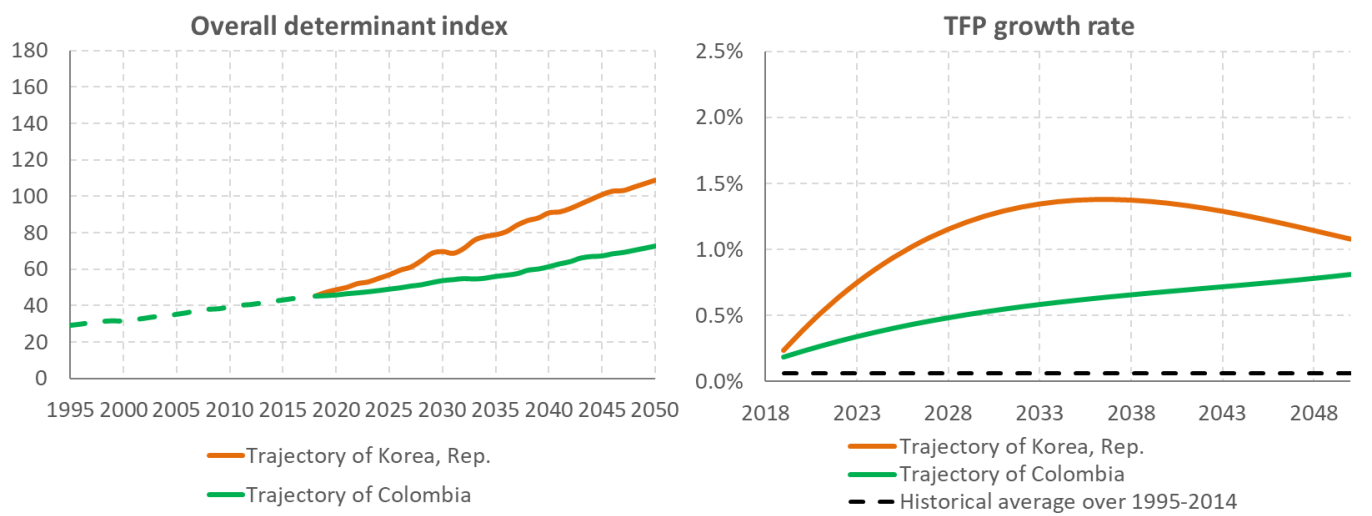

(c) The overall index for the next 3 decades follows the trajectory of Colombia and Korea in 1985-2014, which shows the fastest increase in the overall index in Latin America and among all countries, respectively.

Figure 11. Projected TFP growth rates for Peru under various scenarios.

illustration, we present three sets of scenarios for Peru. They are shown in Figure 11. In each case, we postulate a given path for the overall TFP determinant index from the present to the year 2050 (left panels) and then obtain the corresponding path for TFP growth for the same 
period (right panels).

An important element in all scenarios is the historical level of TFP growth, which drives not only the initial position of TFP growth but also how difficult it is to increase TFP growth further in the future (with higher rates being harder to improve). In the case of Peru, we choose the historical level of TFP growth to be equal to the average for the two most recent decades for which we have data, 1995-2014. This avoids the macroeconomic and social crisis (recession, hyperinflation, civil conflict, and recovery) of the 80s and early 90s. Similar analysis and choices can be made for each country whose future TFP growth is to be simulated.

In scenario 1, the overall TFP determinant index in Peru is assumed to reach the highest current index in Latin America, which corresponds to Chile, in either 15 years (orange line) or 30 years (green line). The target rate of improvement is modest, and, correspondingly, the productivity gains are low. Reaching Chile's current index in 30 years brings no gain in TFP growth and reaching it in 15 years allows to obtain a TFP growth of 0.5 percent. The latter, modest gain, is consistent with a continuation in the rate of improvement in the TFP determinant index that Peru has experienced since the mid-1990s.

Peru's development aspirations demand a larger rate of economic growth, and this, in turn, requires a faster TFP growth rate. This can be achieved only if the pace of reforms to improve the determinants of TFP increases substantially. Scenarios 2 and 3 consider two such alternatives.

In scenario 2, the overall TFP determinant index in Peru is assumed to reach the highest index among all developing countries (to be more precise, among all countries not belonging to the OECD for at least 40 years). This country is Korea. As in scenario 1, we consider two cases, reaching Korea's level in 15 years (orange line) or 30 years (green line). Both represent a departure from the previous trend, especially, of course, the target of achieving Korea's current TFP index in 15 years. The gains in TFP growth are correspondingly large: focusing on the fast improvement case, TFP growth rises from nearly 0 percent to 1.5 percent in five years, reaches 2 percent in twelve years, and then tapers down to about 1.5 percent by 2050 . To be possible, this scenario would represent a radical improvement of sustained and, for Peru's standards, high TFP growth. But is this target unrealistic? Scenario 3 presents a less ambitious and arguably more realistic case.

In scenario 3, the overall TFP determinant index in Peru is assumed to mimic the changes observed in the index of the most improving countries in Latin American and in the world in the last three decades for which we have data, 1985-2014, and then continue with the same trend. These countries are, respectively, Colombia (green line) and Korea (orange line). Imitating the Colombian improvement would render some gains for TFP growth, sustained but slow, approaching 1 percent by 2050. However, this is hardly what Peru needs to boost long-run economic growth. Imitating the Korean improvement is more promising and, of course, more demanding. It would allow Peru to raise its TFP growth from nearly 0 percent to 1 percent in seven years, reach almost 1.5 percent in about fifteen years, and then reduce gradually to over 1 percent by 2050.

For Peru, as for most countries around the world, sustained TFP growth is essential for economic growth. By itself, however, it cannot support an ambitious growth target. It must be

\section{c) PUCP}


accompanied by a strong effort in physical capital accumulation, labor force participation and quality, as well as the required domestic savings.

\section{Conclusion}

This is the background paper for the TFP extension of the World Bank's Long-Term Growth Model (LTGM). It proposes a way to project the future path of TFP growth for most developing countries around the world if they were to follow a program of reforms that would approach them to regional and global leaders. The paper is accompanied by an Excel-based toolkit, which can be used for scenario analysis on TFP and corresponding income growth (available at the LTGM's website: http://www.worldbank.org/LTGM).

Based on a comprehensive literature review, we select innovation, education, market efficiency, infrastructure, and institutions as the five main categories of TFP determinants. For each of these categories, we construct an index as a linear combination of representative indicators (or proxies) by factor analysis, that is, by accounting for as much of the common variance in the indicators as possible. We then combine the five subcomponent indexes into an overall index by the principal component analysis, which accounts for as much of the total variance in the subcomponent indexes as possible.

Using dominance analysis, the variance decomposition of the TFP growth rate into the main subcomponent indexes shows that for OECD countries, market efficiency contributes the most to the variance of TFP growth and infrastructure, the least for the recent decade; and for developing countries, the contribution of education increases continuously and is the largest among the determinants in the recent decade. Although the variance decomposition of TFP into its determinants is not necessarily a guide for policy reform, it illustrates how the observed variation in TFP growth can be explained differentially over time and across development levels. This suggests patterns that countries can use to assess their own progress in the various determinants of productivity.

On its part, regression analysis shows that an increase in the overall determinant index is significantly associated with an increase in the TFP growth rate, controlling for the initial TFP level and country- and time-effects. Countries that have a larger room for improvement in the determinants of TFP and make a stronger effort of reform would experience a larger increase in TFP growth, which is expected to rise over time and then taper down. The slowdown of TFP growth in the long run is explained by the increasing difficulty of expanding TFP when its level is higher (given the estimated negative regression coefficient on past TFP) and the deceleration (in proportional terms) in the TFP determinant index itself.

Though significant and reasonable by historical standards, the increase in TFP growth is projected to be between 2.5-3 percentage points in the best cases of substantial reform, not enough by itself to support overly ambitious economic growth targets. Alongside productivity improvements, savings, investment, labor participation, and human capital formation should continue to figure prominently in countries' growth and development agendas.

This study has some limitations that should be considered when interpreting the results. One 
limitation is that the TFP determinants could be endogenous in relation to TFP growth. To mitigate this risk, we use lagged observations of the TFP determinant index in the variance decomposition and regression analyses. This may be a more straightforward and less biased approach than using instrumental variables that could be questionable (see Young, 2017). Another limitation is that we do not include all possible determinants of productivity, either as broad categories or specific indicators. For instance, we do not directly include geographic conditions, workforce demographics, income and wealth inequality, or firm-specific entrepreneurship, and managerial ability (Feyrer, 2007; Mastromarco and Zago, 2012; Kremer et al., 2019). We attenuate the potential problem by including country-specific effects, a reasonable strategy to control for productivity determinants that are persistent over time. Also, we include a number of indicators that represent not only their limited definition but also proxy for a wider array of variables not represented in our measurements. A third limitation deals with the well-known drawbacks of measuring productivity as a residual. In a sense, the Solow residual is a "measure of our ignorance" (Abramovitz, 1956), capturing not only productivity proper but also a variety of factors, from excess capacity and natural resources to heterogeneous and intangible capital (Hulten, 2001; Corrado et al., 2009). Nevertheless, we believe that focusing on average growth rates of TFP over several years (rather than on TFP levels or high-frequency TFP growth) is conducive to reducing mismeasurement and allowing the possibility of explaining TFP growth (Jorgenson and Griliches, 1967). A fourth limitation is that the study focuses on global patterns, not taking sufficiently into account country heterogeneity. The relative contribution of the determinant indexes to the variance of TFP growth and the impact of the overall determinant index on TFP growth could be different for each country and region, generally depending on the level of economic development and the nature of their political and social environment. Despite these limitations, we expect that this paper and accompanying toolkit can be a starting point - an international benchmark - for researchers and policy makers in their analysis of productivity and growth for particular countries ${ }^{6}$.

${ }^{6}$ See, for instance, Céspedes et al. (forthcoming). 


\title{
Appendix A. Literature Review
}

\author{
1. Innovation (12 studies)
}

\begin{tabular}{|c|c|c|c|}
\hline Study & Country and year & Results & Relationship \\
\hline Nadiri (1993) & $\begin{array}{l}4 \text { industrial countries, } \\
1970-90\end{array}$ & $\begin{array}{l}\text { The results suggest a positive and strong relationship } \\
\text { between research and development }(\mathrm{R} \& \mathrm{D}) \text { expenditu- } \\
\text { res and growth of output or total factor productivity } \\
(\mathrm{TFP}) \text {. }\end{array}$ & + \\
\hline $\begin{array}{l}\text { Coe and Helpman } \\
\text { (1995) }\end{array}$ & $\begin{array}{l}22 \text { industrial countries, } \\
1971-90\end{array}$ & $\begin{array}{l}\text { International R\&D spillovers have beneficial effects on } \\
\text { domestic productivity. The elasticity of TFP with res- } \\
\text { pect to foreign } R \& D \text { expenditure is } 0.02-0.08 \text { for } G 7 \\
\text { countries and } 0.04-0.26 \text { for other small OECD countries. }\end{array}$ & + \\
\hline $\begin{array}{l}\text { Chen and Dahlman } \\
\text { (2004) }\end{array}$ & 92 countries, $1960-2000$ & $\begin{array}{l}\text { The number of patents and journal publications is sta- } \\
\text { tistically significant in terms of real GDP growth via } \\
\text { their effects on the TFP growth rate. }\end{array}$ & + \\
\hline $\begin{array}{l}\text { Furman et al. } \\
(2004)\end{array}$ & 29 countries, 1978-99 & $\begin{array}{l}\text { Innovation-enhancing policies and infrastructure need } \\
\text { to be developed to achieve leadership in innovation, but } \\
\text { these are insufficient unless coupled with ever-increasing } \\
\text { financial and human capital investments in innovation. }\end{array}$ & $+/-$ \\
\hline $\begin{array}{l}\text { Griffith et al. } \\
(2004)\end{array}$ & $\begin{array}{l}12 \text { OECD countries, } \\
1974-90\end{array}$ & $\begin{array}{l}\text { R\&D is statistically and economically important in both } \\
\text { technological catch up and innovation. Human capital } \\
\text { also plays a major role in productivity growth. }\end{array}$ & + \\
\hline $\begin{array}{l}\text { Guellec and van } \\
\text { Pottelsberghe de la } \\
\text { Potterie }(2004)\end{array}$ & $\begin{array}{l}16 \text { OECD countries, } \\
1980-98\end{array}$ & $\begin{array}{l}\mathrm{R} \& \mathrm{D} \text { performed by the business sector, the public sec- } \\
\text { tor, and foreign firms is a significant determinant of } \\
\text { long-term productivity growth. }\end{array}$ & + \\
\hline $\begin{array}{l}\text { Ulku and Subra- } \\
\text { manian }(2004)\end{array}$ & $\begin{array}{l}30 \text { OECD countries, } \\
1981-97\end{array}$ & $\begin{array}{l}\text { The results suggest a positive relationship between per } \\
\text { capita GDP and innovation in both OECD and non- } \\
\text { OECD countries. However, the effect of the R\&D stock } \\
\text { on innovation is significant only in the OECD countries } \\
\text { with large markets. }\end{array}$ & $+/-$ \\
\hline $\begin{array}{l}\text { Jorgenson et al. } \\
(2005)\end{array}$ & $\begin{array}{l}\text { United States, 1990s } \\
\text { and } 2000 \text { s }\end{array}$ & $\begin{array}{l}\text { Industries that produce or use information technology } \\
\text { (IT) account for only } 30 \% \text { of U.S. GDP but contributed } \\
\text { to half of the acceleration in economic growth in the } \\
1990 \text { s and } 2000 \text { s. }\end{array}$ & + \\
\hline $\begin{array}{l}\text { Abdih and Joutz } \\
(2006)\end{array}$ & United States, 1948-97 & $\begin{array}{l}\text { Long-run elasticity of TFP with respect to the stock } \\
\text { of patents is positive, but small. These results seem to } \\
\text { suggest that while research workers benefit greatly from } \\
\text { standing on the shoulders of prior researchers, the know- } \\
\text { ledge that they produce seems to have complex and } \\
\text { slowly diffusing impacts on TFP. }\end{array}$ & + \\
\hline $\begin{array}{l}\text { Jorgenson et al. } \\
(2008)\end{array}$ & $\begin{array}{l}\text { United States 1960- } \\
2006\end{array}$ & $\begin{array}{l}\text { Information technology was critical to the dramatic ac- } \\
\text { celeration of U.S. labor productivity growth in the mid- } \\
\text { 1990s. }\end{array}$ & + \\
\hline Oliner et al. (2008) & $\begin{array}{l}\text { United States, 1990s- } \\
\text { 2000s. }\end{array}$ & $\begin{array}{l}\text { Authors confirm the central role for IT in the producti- } \\
\text { vity revival during } 1995-2000 \text { and show that IT played } \\
\text { a significant, though smaller, role after } 2000 \text {. }\end{array}$ & + \\
\hline $\begin{array}{l}\text { van Ark et al. } \\
(2008)\end{array}$ & $\begin{array}{l}\text { United States, Europe, } \\
\text { 1980s-2000s }\end{array}$ & $\begin{array}{l}\text { The slow-down in productivity in Europe can be attri- } \\
\text { buted to the slower emergence of the knowledge eco- } \\
\text { nomy in Europe compared to the United States. Ex- } \\
\text { planations include lower growth contributions from in- } \\
\text { vestment in information and communication techno- } \\
\text { logy in Europe, the relatively small share of technology- } \\
\text { producing industries in Europe, and slower multifactor } \\
\text { productivity growth (a proxy for advances in technology } \\
\text { and innovation). }\end{array}$ & + \\
\hline
\end{tabular}




\section{Education (9 studies)}

\begin{tabular}{|c|c|c|c|}
\hline Study & Country and year & Results & Relationship \\
\hline $\begin{array}{l}\text { Benhabib and Spiegel } \\
\text { (1994) }\end{array}$ & 78 countries, $1965-85$ & $\begin{array}{l}\text { Human capital is not significant in explaining per } \\
\text { capita growth rates. However, the growth rate of } \\
\text { TFP depends on a nation's human capital stock } \\
\text { level. }\end{array}$ & + \\
\hline Miller et al. (2000) & 83 countries, $1960-89$ & $\begin{array}{l}\text { Human capital generally contributes positively to } \\
\text { TFP. In poor countries, human capital interacts } \\
\text { with openness to achieve a positive effect, on ba- } \\
\text { lance. }\end{array}$ & $+/-$ \\
\hline Barro (2001) & 100 countries, $1965-95$ & $\begin{array}{l}\text { Growth is significantly related to the years of } \\
\text { schooling at the secondary and higher levels for } \\
\text { males and students' test scores (a proxy for the } \\
\text { quality of education). The insignificant relation } \\
\text { between growth and years of schooling for fema- } \\
\text { les implies that women are not well utilized in the } \\
\text { labor markets of many countries. }\end{array}$ & $+/-$ \\
\hline Griffith et al. (2004) & $\begin{array}{l}12 \text { OECD countries, } \\
1974-90\end{array}$ & $\begin{array}{l}\text { Human capital (percentage of higher school attai- } \\
\text { ned in the total population) affects the rate of con- } \\
\text { vergence of TFP growth. }\end{array}$ & + \\
\hline $\begin{array}{l}\text { Benhabib and Spiegel } \\
(2005)\end{array}$ & 27 countries, $1960-95$ & $\begin{array}{l}\text { Results support that human capital plays a posi- } \\
\text { tive role in the determination of total factor pro- } \\
\text { ductivity growth rates through its influence on the } \\
\text { rate of technology catch-up. }\end{array}$ & + \\
\hline $\begin{array}{l}\text { Bronzini and Piselli } \\
(2009)\end{array}$ & Italy, $1985-2001$ & $\begin{array}{l}\text { Elasticity of TFP with respect to years of schooling } \\
\text { is positive and statistically significant }(0.379) \text {. }\end{array}$ & + \\
\hline Coe et al. (2009) & 24 countries, $1971-2004$ & $\begin{array}{l}\text { Authors find evidence that countries where the ea- } \\
\text { se of doing business and the quality of tertiary edu- } \\
\text { cation systems are relatively high tend to benefit } \\
\text { more from their own R\&D efforts, from internatio- } \\
\text { nal R\&D spillovers, and from human capital for- } \\
\text { mation. }\end{array}$ & + \\
\hline Erosa et al. (2010) & United States, 1990-95 & $\begin{array}{l}\text { Human capital accumulation strongly amplifies } \\
\text { TFP differences across countries. }\end{array}$ & + \\
\hline Wei and Hao (2011) & China, 1985-2004 & $\begin{array}{l}\text { School enrollment has significant and positive ef- } \\
\text { fects on the TFP growth of Chinese provinces. } \\
\text { When education quality (as measured by the } \\
\text { teacher-student ratio and government expenditu- } \\
\text { re on education) is incorporated, TFP growth ap- } \\
\text { pears to be significantly enhanced by quality im- } \\
\text { provements in primary education at the national } \\
\text { level. TFP growth is significantly associated with } \\
\text { secondary education in the eastern region; with } \\
\text { primary and university education in the central } \\
\text { region; and with primary education in the western } \\
\text { region. }\end{array}$ & + \\
\hline
\end{tabular}




\section{Market Efficiency (21 studies)}

\begin{tabular}{|c|c|c|c|}
\hline Study & Country and year & Results & Relationship \\
\hline Coe et al. (1997) & $\begin{array}{l}77 \text { developing coun- } \\
\text { tries, } 1971-90\end{array}$ & $\begin{array}{l}\text { Based on data for } 77 \text { developing countries, } R \& D \\
\text { spillovers via trade with } 22 \text { industrial countries are } \\
\text { substantial. }\end{array}$ & + \\
\hline $\begin{array}{l}\text { Borensztein et al. } \\
(1998)\end{array}$ & $70+$ countries, $1970-89$ & $\begin{array}{l}\text { FDI contributes to economic growth only when a } \\
\text { host economy has sufficient capability to absorb } \\
\text { advanced technology. }\end{array}$ & $+/-$ \\
\hline de Mello (1999) & $\begin{array}{l}16 \text { OECD and } 17 \text { non- } \\
\text { OECD, 1970-90 }\end{array}$ & $\begin{array}{l}\text { FDI has a positive relationship with TFP growth } \\
\text { in OECD countries, but a negative relationship in } \\
\text { non-OECD countries. }\end{array}$ & $+/-$ \\
\hline Fagerberg (2000) & 39 countries, $1973-90$ & $\begin{array}{l}\text { While structural change on average has not been } \\
\text { conducive to productivity growth, countries that } \\
\text { have managed to increase their presence in the } \\
\text { technologically most progressive industry (electro- } \\
\text { nics) have experienced higher productivity growth } \\
\text { than other countries. }\end{array}$ & $+/-$ \\
\hline Foster et al. (2001) & United States, 1977-87 & $\begin{array}{l}\text { The contribution of reallocation of outputs and in- } \\
\text { puts from less productive to more productive es- } \\
\text { tablishments plays a significant role in accounting } \\
\text { for aggregate productivity growth. }\end{array}$ & + \\
\hline $\begin{array}{l}\text { Nicoletti and Scarpetta } \\
(2003)\end{array}$ & $\begin{array}{l}18 \text { OECD countries, } \\
1984-98\end{array}$ & $\begin{array}{l}\text { Productivity growth is boosted by reforms that } \\
\text { promote private corporate governance and com- } \\
\text { petition. In manufacturing, the productivity gains } \\
\text { from liberalization are greater the further a given } \\
\text { country is from the technology leader. Strict pro- } \\
\text { duct market regulations - and lack of regulatory } \\
\text { reforms - appear to underlie the meagre producti- } \\
\text { vity performance in industries where Europe has } \\
\text { accumulated a technology gap. }\end{array}$ & + \\
\hline Peneder (2003) & $\begin{array}{l}28 \text { OECD countries, } \\
1990-98\end{array}$ & $\begin{array}{l}\text { Structural change generates positive as well as } \\
\text { negative contributions to aggregate productivity } \\
\text { growth. Because many of these effects net out, } \\
\text { structural change on average appears to have only } \\
\text { a weak impact. Given that certain industries sys- } \\
\text { tematically achieve higher rates of productivity } \\
\text { growth and expansion of output than others, struc- } \\
\text { tural change in favor of specific industries might } \\
\text { still be conducive to aggregate growth. }\end{array}$ & $+/-$ \\
\hline Alfaro et al. (2004) & $49+$ countries, $1975-95$ & $\begin{array}{l}\text { FDI alone plays an ambiguous role in contributing } \\
\text { to economic growth. However, countries with well- } \\
\text { developed financial markets gain significantly from } \\
\text { FDI. }\end{array}$ & + \\
\hline $\begin{array}{l}\text { Dollar and Kraay } \\
(2004)\end{array}$ & $\begin{array}{l}\sim 100 \text { developing and } \\
\text { developed countries, } \\
\text { 1960s-90s }\end{array}$ & $\begin{array}{l}\text { Large increases in trade and significant declines in } \\
\text { tariffs lead to faster growth and poverty reduction } \\
\text { in poor countries. }\end{array}$ & + \\
\hline Jerzmanowski (2007) & $\begin{array}{l}79 \text { developing and } \\
\text { developed countries, } \\
1960-95\end{array}$ & $\begin{array}{l}\text { Inefficiency appears to be the main explanation } \\
\text { for low incomes throughout the world; it explains } \\
43 \% \text { of output variation in } 1995 \text {, and its impor- } \\
\text { tance has increased over time. Countries with an } \\
\text { inadequate mix of inputs are unable to access the } \\
\text { most productive technology. The world technology } \\
\text { frontier appears to be shifting out faster at input } \\
\text { combinations close to that of the R\&D leader. }\end{array}$ & + \\
\hline
\end{tabular}


(Continued)

\begin{tabular}{|c|c|c|c|}
\hline Study & Country and year & Results & Relationship \\
\hline Mendi (2007) & $\begin{array}{l}16 \text { OECD countries, } \\
1971-95\end{array}$ & $\begin{array}{l}\text { Within OECD countries that are not in the G7, } \\
\text { technology imports increase the host country's } \\
\text { TFP. The effect is stronger in the initial years of } \\
\text { the sampling period. There is no evidence on this } \\
\text { positive effect of technology trade on productivity } \\
\text { among G7 countries. }\end{array}$ & $+/-$ \\
\hline Arnold et al. (2008) & $\begin{array}{l}\text { OECD countries, 1985- } \\
2004\end{array}$ & $\begin{array}{l}\text { Tight regulation of services has slowed down } \\
\text { growth in sectors that use IT by hindering the allo- } \\
\text { cation of resources toward the most dynamic and } \\
\text { efficient firms. Regulations especially hurt firms } \\
\text { that are catching up to the technology frontier and } \\
\text { that are close to international best practice. }\end{array}$ & + \\
\hline $\begin{array}{l}\text { Chanda and Dalgaard } \\
\text { (2008) }\end{array}$ & $40+$ countries, 1985 & $\begin{array}{l}\text { A development accounting analysis suggests that } \\
\text { as much as } 85 \% \text { of the international variation in } \\
\text { aggregate TFP can be attributed to variation in } \\
\text { relative efficiency across sectors. }\end{array}$ & + \\
\hline $\begin{array}{l}\text { Haltiwanger et al. } \\
(2008)\end{array}$ & $\begin{array}{l}16 \text { industrial and emer- } \\
\text { ging economies, 1990s }\end{array}$ & $\begin{array}{l}\text { Hiring and firing costs tend to curb job flows, par- } \\
\text { ticularly in those industries and firm size classes } \\
\text { that require more frequent labor adjustment. }\end{array}$ & + \\
\hline $\begin{array}{l}\text { Lentz and Mortensen } \\
(2008)\end{array}$ & $\begin{array}{l}\text { Denmark, } 4900 \text { firms, } \\
\text { 1992-97 }\end{array}$ & $\begin{array}{l}\text { The estimated model implies that more productive } \\
\text { firms in each cohort grow faster and consequently } \\
\text { crowd out less productive firms in steady state. } \\
\text { This selection effect accounts for } 53 \% \text { of aggregate } \\
\text { growth in the estimated version of the model. }\end{array}$ & + \\
\hline Alfaro et al. (2009) & $60+$ countries, $1975-95$ & $\begin{array}{l}\text { FDI alone plays an ambiguous role in contributing } \\
\text { to economic growth. However, countries with well- } \\
\text { developed financial markets gain significantly from } \\
\text { FDI. }\end{array}$ & $+/-$ \\
\hline Bridgman et al. (2009) & $\begin{array}{l}\text { United States, sugar } \\
\text { manufacturing firms, } \\
1934-74\end{array}$ & $\begin{array}{l}\text { Government's enforcement on domestic and im- } \\
\text { port sales quotas significantly distorted sugar pro- } \\
\text { duction at each factory and the location of the } \\
\text { industry. }\end{array}$ & + \\
\hline Chang et al. (2009) & 82 countries, $1960-2000$ & $\begin{array}{l}\text { The growth effects of openness may be signifi- } \\
\text { cantly improved if certain complementary reforms } \\
\text { are undertaken in the areas of investment in edu- } \\
\text { cation, financial depth, inflation stabilization, pu- } \\
\text { blic infrastructure, governance, labor market flexi- } \\
\text { bility, ease of firm entry, and ease of firm exit. }\end{array}$ & + \\
\hline $\begin{array}{l}\text { Hsieh and Klenow } \\
(2009)\end{array}$ & $\begin{array}{l}\text { China }(1998-2005) \\
\text { and India }(1987-95) \\
\text { vs. United States } \\
(1977-97)\end{array}$ & $\begin{array}{l}\text { When capital and labor are hypothetically reallo- } \\
\text { cated to equalize marginal products to the extent } \\
\text { observed in the United States, manufacturing TFP } \\
\text { gains are expected to be substantial in China and } \\
\text { India. }\end{array}$ & + \\
\hline $\begin{array}{l}\text { Petrin and Sivadasan } \\
(2011)\end{array}$ & $\begin{array}{l}\text { Chile, manufacturing } \\
\text { firms, 1982-94 }\end{array}$ & $\begin{array}{l}\text { Comparing blue- and white-color labor in terms of } \\
\text { the marginal product and cost of an input suggests } \\
\text { that the increase in severance pay is associated } \\
\text { with the decrease in allocative efficiency. }\end{array}$ & + \\
\hline $\begin{array}{l}\text { Bartelsman et al. } \\
(2016)\end{array}$ & $\begin{array}{l}\text { European countries, } \\
\text { United States, 1980s- } \\
2000 \text { s }\end{array}$ & $\begin{array}{l}\text { Countries which have extensive employment pro- } \\
\text { tection legislation (EPL) benefit less from the arri- } \\
\text { val of new risky technology than countries with li- } \\
\text { mited EPL. The model is consistent with the slow- } \\
\text { down in productivity in the European Union rela- } \\
\text { tive to the United States since the mid-1990s. }\end{array}$ & + \\
\hline
\end{tabular}




\section{Infrastructure (11 studies)}

\begin{tabular}{|c|c|c|c|}
\hline Authors & Country and year & Results & Relationship \\
\hline Aschauer (1989) & United States, 1949-85 & There is a large return to public investment. & + \\
\hline Munnell (1992) & Not applicable & $\begin{array}{l}\text { On balance, public investment has a positive ef- } \\
\text { fect on private investment, output, and employ- } \\
\text { ment growth. }\end{array}$ & + \\
\hline Hulten (1996) & $\begin{array}{l}4 \quad \text { East Asian and } \\
17 \text { African countries, } \\
1970-90\end{array}$ & $\begin{array}{l}25 \% \text { of the growth difference between East Asia } \\
\text { and Africa is due to inefficient use of infrastructu- } \\
\text { re. This result may partly proxy for TFP differen- } \\
\text { ces. }\end{array}$ & + \\
\hline Pritchett (1996) & $\begin{array}{l}\sim \quad 100 \quad \text { countries, } \\
\text { thought experiment }\end{array}$ & $\begin{array}{l}\text { Pritchett presents theory and calculations to show } \\
\text { that part of the explanation of slow growth in } \\
\text { many poor countries is not that governments did } \\
\text { not spend on investments, but that these invest- } \\
\text { ments did not create productive capital. A variety } \\
\text { of calculations suggest that in a typical developing } \\
\text { country, less than } 50 \text { cents of capital were created } \\
\text { for each public dollar invested. }\end{array}$ & $+/-$ \\
\hline Galiani et al. (2005) & Argentina, 1990s & $\begin{array}{l}\text { Improved water services are associated with sig- } \\
\text { nificant reductions in deaths from infectious and } \\
\text { parasitic diseases. }\end{array}$ & + \\
\hline $\begin{array}{l}\text { Canning and Pedroni } \\
\text { (2008) }\end{array}$ & $>40$ countries, $1950-92$ & $\begin{array}{l}\text { While infrastructure does tend to cause long-run } \\
\text { economic growth, there is substantial variation } \\
\text { across countries. }\end{array}$ & + \\
\hline Straub (2008) & $\begin{array}{l}140 \text { countries, 1989- } \\
2007\end{array}$ & $\begin{array}{l}\text { Good infrastructure allows firms to have more pro- } \\
\text { ductive investments in machinery, reduces time } \\
\text { wasted commuting, promotes better health and } \\
\text { education, and so on. The analysis obtains posi- } \\
\text { tive effects of infrastructure on growth when it } \\
\text { uses physical indicators of infrastructure. Howe- } \\
\text { ver, the effects are not clear when infrastructure } \\
\text { investment flows are used as proxies for infrastruc- } \\
\text { ture. }\end{array}$ & $+/-$ \\
\hline $\begin{array}{l}\text { Calderón and Servén } \\
\text { (2010) }\end{array}$ & $\begin{array}{l}>100 \text { countries, 1960- } \\
2005\end{array}$ & $\begin{array}{l}\text { The estimates illustrate the potential contribu- } \\
\text { tion of infrastructure development to growth and } \\
\text { equity across Africa. }\end{array}$ & + \\
\hline $\begin{array}{l}\text { Loayza and Odawara } \\
(2010)\end{array}$ & $\begin{array}{l}\text { Egypt, Arab Rep., } \\
\text { 1971-2005 }\end{array}$ & $\begin{array}{l}\text { An increase in infrastructure expenditures from } 5 \\
\text { to } 6 \text { percent of gross domestic product would rai- } \\
\text { se the annual per capita growth rate of GDP by } \\
\text { about } 0.5 \text { percentage points in a decade's time and } \\
1 \text { percentage point by the third decade. }\end{array}$ & + \\
\hline $\begin{array}{l}\text { Calderón and Servén } \\
(2012)\end{array}$ & $\begin{array}{l}\text { Latin America, 1981- } \\
2005\end{array}$ & $\begin{array}{l}\text { Poor infrastructure is a key obstacle to econo- } \\
\text { mic development. The experience of Latin Ame- } \\
\text { rica shows that there is no question that private } \\
\text { participation did deliver some efficiency and qua- } \\
\text { lity gains. But they were held back by weak re- } \\
\text { gulatory and supervisory frameworks, and poorly } \\
\text { designed concession and privatization agreements, } \\
\text { which led to ubiquitous renegotiations and ended } \\
\text { up costing governments enormous sums. }\end{array}$ & + \\
\hline $\begin{array}{l}\text { (Calderón and Servén, } \\
\text { 2014) }\end{array}$ & Not applicable & $\begin{array}{l}\text { Recent theoretical and empirical literature finds } \\
\text { positive effects of infrastructure development on } \\
\text { income growth and, more tentatively, on distribu- } \\
\text { tive equity. }\end{array}$ & + \\
\hline
\end{tabular}




\section{Institutions (10 studies)}

\begin{tabular}{|c|c|c|c|}
\hline Study & Country and year & Results & Relationship \\
\hline Barro (1991) & 98 countries, $1960-85$ & $\begin{array}{l}\text { Growth is inversely related to the share of government } \\
\text { consumption in GDP, but insignificantly related to } \\
\text { the share of public investment. Growth rates are po- } \\
\text { sitively related to measures of political stability and } \\
\text { inversely related to a proxy for market distortions. }\end{array}$ & $+/-$ \\
\hline $\begin{array}{l}\text { Przeworski and Li- } \\
\text { mongi (1993) }\end{array}$ & $\begin{array}{l}\text { Review of previous stu- } \\
\text { dies }\end{array}$ & $\begin{array}{l}\text { Political institutions do matter for growth, but thin- } \\
\text { king in terms of regimes, democracy, autocracy, or } \\
\text { bureaucracy does not seem to capture the relevant } \\
\text { differences. }\end{array}$ & $+/-$ \\
\hline Sachs (2003) & $60+$ countries, 1995 & $\begin{array}{l}\text { The transmission of malaria, which is strongly affec- } \\
\text { ted by ecological conditions, directly affects the level } \\
\text { of per capita income after controlling for the quality } \\
\text { of institutions. }\end{array}$ & $+/-$ \\
\hline $\begin{array}{l}\text { Hall and Jones } \\
(1999)\end{array}$ & $\begin{array}{l}100+\text { countries, } 1986- \\
95\end{array}$ & $\begin{array}{l}\text { Output is driven by differences in institutions and } \\
\text { government policies, which the authors call "social in- } \\
\text { frastructure". The authors treat social infrastructu- } \\
\text { re as endogenous, determined historically by location } \\
\text { and other factors captured in part by language. }\end{array}$ & + \\
\hline Ghali (1999) & $\begin{array}{l}10 \text { OECD countries, } \\
1970-94\end{array}$ & $\begin{array}{l}\text { A big government size causes economic growth with } \\
\text { some disparities, through the increase of government } \\
\text { spending, investment, or international trade. }\end{array}$ & $+/-$ \\
\hline $\begin{array}{l}\text { Dar and AmirKhalk- } \\
\text { hali }(2002)\end{array}$ & 19 OECD, 1971-99 & $\begin{array}{l}\text { Total factor productivity on average is weaker in } \\
\text { countries where government size is larger due to } \\
\text { policy-induced distortions such as burdensome taxa- } \\
\text { tion, crowding-out effects for new capital that embo- } \\
\text { dies new technology, and the lack of market forces } \\
\text { that could foster efficient use of resources. }\end{array}$ & $+/-$ \\
\hline $\begin{array}{l}\text { Easterly and Levine } \\
\text { (2003) }\end{array}$ & $64+$ countries, 1995 & $\begin{array}{l}\text { Tropics, germs, and crops affect development through } \\
\text { institutions. No evidence is found that tropics, germs, } \\
\text { and crops affect country incomes directly other than } \\
\text { through institutions. Macroeconomic policies on de- } \\
\text { velopment are not significant once the factor of insti- } \\
\text { tutional quality is controlled. }\end{array}$ & + \\
\hline $\begin{array}{l}\text { Acemoglu et al. } \\
(2004)\end{array}$ & $\begin{array}{l}\text { Korea, Rep., colonized } \\
\text { countries by European } \\
\text { powers }\end{array}$ & $\begin{array}{l}\text { Differences in economic institutions, rather than geo- } \\
\text { graphy or culture, cause differences in per capita } \\
\text { incomes. Countries with more secure property rights } \\
\text { (that is, with better economic institutions), have } \\
\text { higher average incomes. }\end{array}$ & + \\
\hline Rodrik et al. (2004) & $79+$ countries, 1995 & $\begin{array}{l}\text { The study estimates the respective contributions of } \\
\text { institutions, geography, and trade in determining in- } \\
\text { come levels around the world, using recently develo- } \\
\text { ped instrumental variables for institutions and tra- } \\
\text { de. Results indicate that the quality of institutions } \\
\text { "trumps" everything else. }\end{array}$ & + \\
\hline $\begin{array}{l}\text { Chanda and Dal- } \\
\text { gaard (2008) }\end{array}$ & $40+$ countries, 1985 & $\begin{array}{l}\text { The study compiles a Government Anti-Diversionary } \\
\text { Policy index (GADP),an average of five indices cap- } \\
\text { turing the quality of government: rule of law, bureau- } \\
\text { cratic quality, risk of expropriation, government re- } \\
\text { pudiation of contracts, and corruption. The GADP } \\
\text { is strongly related to total factor productivity. Intro- } \\
\text { ducing geographical variables reduces the impact of } \\
\text { GADP considerably. Geographical explanations seem } \\
\text { to be as important as institutional explanations. }\end{array}$ & + \\
\hline
\end{tabular}




\section{Appendix B. Countries in The Sample}

Table B.1 shows countries we use in the analysis with their region and income quintile by group depending on analysis type (descriptive and statistical), data source (PWT, GTAP, and WDI), and some characteristics (oil rent and population). We calculate income quintiles for nonOECD countries using the average GDP per capita over 1985-2014 (World Bank, 2017e). The OECD group includes high-income countries that have been members of the OECD for more than 40 years.

Table B.1

Countries with region and income quintile by group.

\begin{tabular}{|c|c|c|c|}
\hline \multicolumn{4}{|c|}{ 1. Countries from PWT 9.0 for the statistical analysis (98) } \\
\hline ID & Country & Region & Income quintile* \\
\hline 1 & Argentina & Latin America and Caribbean & 5 \\
\hline 2 & Armenia & Europe and Central Asia & 3 \\
\hline 3 & Australia & OECD & Not applicable \\
\hline 4 & Austria & OECD & Not applicable \\
\hline 5 & Belgium & OECD & Not applicable \\
\hline 6 & Benin & Sub-Saharan Africa & 2 \\
\hline 7 & Bolivia & Latin America and Caribbean & 3 \\
\hline 8 & Botswana & Sub-Saharan Africa & 4 \\
\hline 9 & Brazil & Latin America and Caribbean & 5 \\
\hline 10 & Bulgaria & Europe and Central Asia & 4 \\
\hline 11 & Burkina Faso & Sub-Saharan Africa & 1 \\
\hline 12 & Burundi & Sub-Saharan Africa & 1 \\
\hline 13 & Cameroon & Sub-Saharan Africa & 2 \\
\hline 14 & Canada & OECD & Not applicable \\
\hline 15 & Central African Republic & Sub-Saharan Africa & 1 \\
\hline 16 & Chile & Latin America and Caribbean & 5 \\
\hline 17 & China & East Asia and Pacific & 3 \\
\hline 18 & Colombia & Latin America and Caribbean & 4 \\
\hline 19 & Costa Rica & Latin America and Caribbean & 4 \\
\hline 20 & Côte d'Ivoire & Sub-Saharan Africa & 2 \\
\hline 21 & Croatia & Europe and Central Asia & 5 \\
\hline 22 & Czech Republic & Europe and Central Asia & 5 \\
\hline 23 & Denmark & OECD & Not applicable \\
\hline 24 & Dominican Republic & Latin America and Caribbean & 4 \\
\hline 25 & Ecuador & Latin America and Caribbean & 4 \\
\hline 26 & Egypt, Arab Rep. & Middle East and North Africa & 3 \\
\hline 27 & Finland & OECD & Not applicable \\
\hline 28 & France & OECD & Not applicable \\
\hline 29 & Germany & OECD & Not applicable \\
\hline 30 & Greece & OECD & Not applicable \\
\hline 31 & Guatemala & Latin America and Caribbean & 3 \\
\hline 32 & Honduras & Latin America and Caribbean & 3 \\
\hline 33 & Hong Kong SAR, China & East Asia and Pacific & 5 \\
\hline 34 & Hungary & Europe and Central Asia & 5 \\
\hline 35 & India & South Asia & 2 \\
\hline 36 & Indonesia & East Asia and Pacific & 3 \\
\hline 37 & Iran, Islamic Rep. & Middle East and North Africa & 4 \\
\hline 38 & Ireland & OECD & Not applicable \\
\hline 39 & Israel & Middle East and North Africa & 5 \\
\hline 40 & Italy & OECD & Not applicable \\
\hline 41 & Jamaica & Latin America and Caribbean & 4 \\
\hline
\end{tabular}


Table B.1 (continued)

\begin{tabular}{|c|c|c|c|}
\hline 42 & Japan & OECD & Not applicable \\
\hline 43 & Jordan & Middle East and North Africa & 3 \\
\hline 44 & Kazakhstan & Europe and Central Asia & 4 \\
\hline 45 & Kenya & Sub-Saharan Africa & 2 \\
\hline 46 & Korea, Rep. & East Asia and Pacific & 5 \\
\hline 47 & Kyrgyz Republic & Europe and Central Asia & 2 \\
\hline 48 & Lao PDR & East Asia and Pacific & 2 \\
\hline 49 & Lesotho & Sub-Saharan Africa & 2 \\
\hline 50 & Lithuania & Europe and Central Asia & 5 \\
\hline 51 & Malaysia & East Asia and Pacific & 5 \\
\hline 52 & Mauritania & Sub-Saharan Africa & 2 \\
\hline 53 & Mexico & Latin America and Caribbean & 5 \\
\hline 54 & Moldova & Europe and Central Asia & 3 \\
\hline 55 & Mongolia & East Asia and Pacific & 3 \\
\hline 56 & Morocco & Middle East and North Africa & 3 \\
\hline 57 & Mozambique & Sub-Saharan Africa & 1 \\
\hline 58 & Namibia & Sub-Saharan Africa & 4 \\
\hline 59 & Netherlands & OECD & Not applicable \\
\hline 60 & New Zealand & OECD & Not applicable \\
\hline 61 & Nicaragua & Latin America and Caribbean & 3 \\
\hline 62 & Niger & Sub-Saharan Africa & 1 \\
\hline 63 & Nigeria & Sub-Saharan Africa & 3 \\
\hline 64 & Norway & OECD & Not applicable \\
\hline 65 & Panama & Latin America and Caribbean & 4 \\
\hline 66 & Paraguay & Latin America and Caribbean & 3 \\
\hline 67 & Peru & Latin America and Caribbean & 4 \\
\hline 68 & Philippines & East Asia and Pacific & 3 \\
\hline 69 & Poland & Europe and Central Asia & 5 \\
\hline 70 & Portugal & OECD & Not applicable \\
\hline 71 & Qatar & Middle East and North Africa & 5 \\
\hline 72 & Romania & Europe and Central Asia & 4 \\
\hline 73 & Russian Federation & Europe and Central Asia & 5 \\
\hline 74 & Rwanda & Sub-Saharan Africa & 1 \\
\hline 75 & Senegal & Sub-Saharan Africa & 2 \\
\hline 76 & Serbia & Europe and Central Asia & 4 \\
\hline 77 & Sierra Leone & Sub-Saharan Africa & 1 \\
\hline 78 & Singapore & East Asia and Pacific & 5 \\
\hline 79 & Slovak Republic & Europe and Central Asia & 5 \\
\hline 80 & Slovenia & Europe and Central Asia & 5 \\
\hline 81 & South Africa & Sub-Saharan Africa & 4 \\
\hline 82 & Spain & OECD & Not applicable \\
\hline 83 & Sri Lanka & South Asia & 3 \\
\hline 84 & Sudan & Sub-Saharan Africa & 2 \\
\hline 85 & Sweden & OECD & Not applicable \\
\hline 86 & Switzerland & OECD & Not applicable \\
\hline 87 & Tajikistan & Europe and Central Asia & 2 \\
\hline 88 & Tanzania & Sub-Saharan Africa & 1 \\
\hline 89 & Thailand & East Asia and Pacific & 4 \\
\hline 90 & Togo & Sub-Saharan Africa & 1 \\
\hline 91 & Tunisia & Middle East and North Africa & 3 \\
\hline 92 & Turkey & Europe and Central Asia & 5 \\
\hline 93 & Ukraine & Europe and Central Asia & 3 \\
\hline 94 & United Kingdom & OECD & Not applicable \\
\hline 95 & United States & OECD & Not applicable \\
\hline 96 & Uruguay & Latin America and Caribbean & 5 \\
\hline 97 & Venezuela, RB & Latin America and Caribbean & 5 \\
\hline 98 & Zimbabwe & Sub-Saharan Africa & 2 \\
\hline
\end{tabular}

(Continued on next page) 
Table B.1 (continued)

\begin{tabular}{|c|c|c|c|}
\hline \multicolumn{4}{|c|}{ 2. Additional countries using GTAP 9.0 (for labor share) for the descriptive analysis of TFP growth (16) } \\
\hline ID & Country & Region & Income quintile* \\
\hline 1 & Albania & Europe and Central Asia & 3 \\
\hline 2 & Bangladesh & South Asia & 1 \\
\hline 3 & Cambodia & East Asia and Pacific & 1 \\
\hline 4 & Congo, Dem. Rep. & Sub-Saharan Africa & 1 \\
\hline 5 & Ethiopia & Sub-Saharan Africa & 1 \\
\hline 6 & Ghana & Sub-Saharan Africa & 2 \\
\hline 7 & Liberia & Sub-Saharan Africa & 1 \\
\hline 8 & Madagascar & Sub-Saharan Africa & 1 \\
\hline 9 & Malawi & Sub-Saharan Africa & 1 \\
\hline 10 & Mali & Sub-Saharan Africa & 2 \\
\hline 11 & Nepal & South Asia & 1 \\
\hline 12 & Pakistan & South Asia & 2 \\
\hline 13 & Uganda & Sub-Saharan Africa & 1 \\
\hline 14 & Vietnam & East Asia and Pacific & 2 \\
\hline 15 & Yemen, Rep. & Middle East and North Africa & 2 \\
\hline 16 & Zambia & Sub-Saharan Africa & 2 \\
\hline \multicolumn{4}{|c|}{ 3. Additional countries for the descriptive analysis of the determinant indexes (22) } \\
\hline ID & Country & Region & Income quintile* \\
\hline 1 & Afghanistan & South Asia & 1 \\
\hline 2 & Algeria & Middle East and North Africa & 4 \\
\hline 3 & Azerbaijan & Europe and Central Asia & 3 \\
\hline 4 & Belarus & Europe and Central Asia & 4 \\
\hline 5 & Bosnia and Herzegovina & Europe and Central Asia & 4 \\
\hline 6 & Chad & Sub-Saharan Africa & 2 \\
\hline 7 & Cuba & Latin America and Caribbean & 4 \\
\hline 8 & El Salvador & Latin America and Caribbean & 3 \\
\hline 9 & Eritrea & Sub-Saharan Africa & 1 \\
\hline 10 & Gambia, The & Sub-Saharan Africa & 1 \\
\hline 11 & Georgia & Europe and Central Asia & 3 \\
\hline 12 & Guinea & Sub-Saharan Africa & 1 \\
\hline 13 & Haiti & Latin America and Caribbean & 2 \\
\hline 14 & Lebanon & Middle East and North Africa & 4 \\
\hline 15 & Macedonia, FYR & Europe and Central Asia & 4 \\
\hline 16 & Myanmar & East Asia and Pacific & 1 \\
\hline 17 & Papua New Guinea & East Asia and Pacific & 2 \\
\hline 18 & Puerto Rico & Latin America and Caribbean & 5 \\
\hline 19 & Turkmenistan & Europe and Central Asia & 4 \\
\hline 20 & United Arab Emirates & Middle East and North Africa & 5 \\
\hline 21 & Uzbekistan & Europe and Central Asia & 2 \\
\hline 22 & West Bank and Gaza & Middle East and North Africa & 3 \\
\hline \multicolumn{4}{|c|}{ 4. Additional countries to include in the LTGM toolkit: high oil rent (10) } \\
\hline ID & Country & Region & Income quintile* \\
\hline 1 & Angola & Sub-Saharan Africa & 3 \\
\hline 2 & Congo, Rep. & Sub-Saharan Africa & 3 \\
\hline 3 & Equatorial Guinea & Sub-Saharan Africa & 5 \\
\hline 4 & Gabon & Sub-Saharan Africa & 5 \\
\hline 5 & Iraq & Middle East and North Africa & 4 \\
\hline 6 & Kuwait & Middle East and North Africa & 5 \\
\hline 7 & Libya & Middle East and North Africa & 5 \\
\hline 8 & Oman & Middle East and North Africa & 5 \\
\hline 9 & Saudi Arabia & Middle East and North Africa & 5 \\
\hline 10 & South Sudan & Sub-Saharan Africa & 2 \\
\hline
\end{tabular}

(Continued on next page) 
Table B.1 (continued)

\begin{tabular}{|c|c|c|c|}
\hline ID & Country & Region & Income quintile* \\
\hline 1 & American Samoa & East Asia and Pacific & 5 \\
\hline 2 & Andorra & Europe and Central Asia & 5 \\
\hline 3 & Antigua and Barbuda & Latin America and Caribbean & 5 \\
\hline 4 & Aruba & Latin America and Caribbean & 5 \\
\hline 5 & Bahamas, The & Latin America and Caribbean & 5 \\
\hline 6 & Bahrain & Middle East and North Africa & 5 \\
\hline 7 & Barbados & Latin America and Caribbean & 5 \\
\hline 8 & Belize & Latin America and Caribbean & 4 \\
\hline 9 & Bhutan & South Asia & 2 \\
\hline 10 & Brunei Darussalam & East Asia and Pacific & 5 \\
\hline 11 & Cabo Verde & Sub-Saharan Africa & 3 \\
\hline 12 & Comoros & Sub-Saharan Africa & 2 \\
\hline 13 & Cyprus & Europe and Central Asia & 5 \\
\hline 14 & Djibouti & Middle East and North Africa & 2 \\
\hline 15 & Dominica & Latin America and Caribbean & 4 \\
\hline 16 & Estonia & Europe and Central Asia & 5 \\
\hline 17 & Fiji & East Asia and Pacific & 4 \\
\hline 18 & Greenland & Europe and Central Asia & 5 \\
\hline 19 & Grenada & Latin America and Caribbean & 4 \\
\hline 20 & Guam & East Asia and Pacific & 5 \\
\hline 21 & Guinea-Bissau & Sub-Saharan Africa & 1 \\
\hline 22 & Guyana & Latin America and Caribbean & 3 \\
\hline 23 & Iceland & Europe and Central Asia & 5 \\
\hline 24 & Kiribati & East Asia and Pacific & 3 \\
\hline 25 & Latvia & Europe and Central Asia & 5 \\
\hline 26 & Liechtenstein & Europe and Central Asia & 5 \\
\hline 27 & Luxembourg & Europe and Central Asia & 5 \\
\hline 28 & Macao SAR, China & East Asia and Pacific & 5 \\
\hline 29 & Malta & Middle East and North Africa & 5 \\
\hline 30 & Marshall Islands & East Asia and Pacific & 3 \\
\hline 31 & Mauritius & Sub-Saharan Africa & 4 \\
\hline 32 & Micronesia, Fed. Sts. & East Asia and Pacific & 3 \\
\hline 33 & Monaco & Europe and Central Asia & 5 \\
\hline 34 & Montenegro & Europe and Central Asia & 4 \\
\hline 35 & Palau & East Asia and Pacific & 5 \\
\hline 36 & Samoa & East Asia and Pacific & 3 \\
\hline 37 & São Tomé and Príncipe & Sub-Saharan Africa & 2 \\
\hline 38 & Seychelles & Sub-Saharan Africa & 5 \\
\hline 39 & Solomon Islands & East Asia and Pacific & 2 \\
\hline 40 & St. Kitts and Nevis & Latin America and Caribbean & 5 \\
\hline 41 & St. Lucia & Latin America and Caribbean & 4 \\
\hline 42 & St. Vincent and the Grenadines & Latin America and Caribbean & 4 \\
\hline 43 & St. Suriname & Latin America and Caribbean & 4 \\
\hline 44 & Eswatini & Sub-Saharan Africa & 3 \\
\hline 45 & Timor-Leste & East Asia and Pacific & 2 \\
\hline 46 & Tonga & East Asia and Pacific & 3 \\
\hline 47 & Trinidad and Tobago & Latin America and Caribbean & 5 \\
\hline 48 & Tuvalu & East Asia and Pacific & 3 \\
\hline 49 & Vanuatu & East Asia and Pacific & 3 \\
\hline 50 & Virgin Islands (U.S.) & Latin America and Caribbean & 5 \\
\hline
\end{tabular}

(Continued on next page) 
Table B.1 (continued)

\begin{tabular}{|c|c|c|c|}
\hline \multicolumn{4}{|c|}{ 6. Countries for the statistical analysis with WDI dataset in Appendix E (96) } \\
\hline ID & Country & Region & Income quintile* $^{*}$ \\
\hline 1 & Albania & Europe and Central Asia & 3 \\
\hline 2 & Argentina & Latin America and Caribbean & 5 \\
\hline 3 & Australia & OECD & Not applicable \\
\hline 4 & Austria & OECD & Not applicable \\
\hline 5 & Bangladesh & South Asia & 1 \\
\hline 6 & Belgium & OECD & Not applicable \\
\hline 7 & Benin & Sub-Saharan Africa & 2 \\
\hline 8 & Bolivia & Latin America and Caribbean & 3 \\
\hline 9 & Botswana & Sub-Saharan Africa & 4 \\
\hline 10 & Brazil & Latin America and Caribbean & 5 \\
\hline 11 & Bulgaria & Europe and Central Asia & 4 \\
\hline 12 & Burkina Faso & Sub-Saharan Africa & 1 \\
\hline 13 & Burundi & Sub-Saharan Africa & 1 \\
\hline 14 & Cambodia & East Asia and Pacific & 1 \\
\hline 15 & Cameroon & Sub-Saharan Africa & 2 \\
\hline 16 & Canada & OECD & Not applicable \\
\hline 17 & Central African Republic & Sub-Saharan Africa & 1 \\
\hline 18 & Chile & Latin America and Caribbean & 5 \\
\hline 19 & China & East Asia and Pacific & 3 \\
\hline 20 & Colombia & Latin America and Caribbean & 4 \\
\hline 21 & Congo, Dem. Rep. & Sub-Saharan Africa & 1 \\
\hline 22 & Côte d'Ivoire & Sub-Saharan Africa & 2 \\
\hline 23 & Denmark & OECD & Not applicable \\
\hline 24 & Dominican Republic & Latin America and Caribbean & 4 \\
\hline 25 & Ecuador & Latin America and Caribbean & 4 \\
\hline 26 & Egypt, Arab Rep. & Middle East and North Africa & 3 \\
\hline 27 & El Salvador & Latin America and Caribbean & 3 \\
\hline 28 & Finland & OECD & Not applicable \\
\hline 29 & France & OECD & Not applicable \\
\hline 30 & Germany & OECD & Not applicable \\
\hline 31 & Ghana & Sub-Saharan Africa & 2 \\
\hline 32 & Greece & OECD & Not applicable \\
\hline 33 & Guatemala & Latin America and Caribbean & 3 \\
\hline 34 & Honduras & Latin America and Caribbean & 3 \\
\hline 35 & Hong Kong SAR, China & East Asia and Pacific & 5 \\
\hline 36 & Hungary & Europe and Central Asia & 5 \\
\hline 37 & India & South Asia & 2 \\
\hline 38 & Indonesia & East Asia and Pacific & 3 \\
\hline 39 & Iran, Islamic Rep. & Middle East and North Africa & 4 \\
\hline 40 & Ireland & OECD & Not applicable \\
\hline 41 & Israel & Middle East and North Africa & 5 \\
\hline 42 & Italy & OECD & Not applicable \\
\hline 43 & Jamaica & Latin America and Caribbean & 4 \\
\hline 44 & Japan & OECD & Not applicable \\
\hline 45 & Jordan & Middle East and North Africa & 3 \\
\hline 46 & Kenya & Sub-Saharan Africa & 2 \\
\hline 47 & Korea, Rep. & East Asia and Pacific & 5 \\
\hline 48 & Lao PDR & East Asia and Pacific & 2 \\
\hline 49 & Liberia & Sub-Saharan Africa & 1 \\
\hline 50 & Madagascar & Sub-Saharan Africa & 1 \\
\hline 51 & Malawi & Sub-Saharan Africa & 1 \\
\hline 52 & Malaysia & East Asia and Pacific & 5 \\
\hline 53 & Mali & Sub-Saharan Africa & 2 \\
\hline 54 & Mauritania & Sub-Saharan Africa & 2 \\
\hline
\end{tabular}


Table B.1 (continued)

\begin{tabular}{|c|c|c|c|}
\hline 55 & Mexico & Latin America and Caribbean & 5 \\
\hline 56 & Mongolia & East Asia and Pacific & 3 \\
\hline 57 & Morocco & Middle East and North Africa & 3 \\
\hline 58 & Mozambique & Sub-Saharan Africa & 1 \\
\hline 59 & Namibia & Sub-Saharan Africa & 4 \\
\hline 60 & Nepal & South Asia & 1 \\
\hline 61 & Netherlands & OECD & Not applicable \\
\hline 62 & New Zealand & OECD & Not applicable \\
\hline 63 & Nicaragua & Latin America and Caribbean & 3 \\
\hline 64 & Niger & Sub-Saharan Africa & 1 \\
\hline 65 & Nigeria & Sub-Saharan Africa & 3 \\
\hline 66 & Norway & OECD & Not applicable \\
\hline 67 & Pakistan & South Asia & 2 \\
\hline 68 & Panama & Latin America and Caribbean & 4 \\
\hline 69 & Paraguay & Latin America and Caribbean & 3 \\
\hline 70 & Peru & Latin America and Caribbean & 4 \\
\hline 71 & Philippines & East Asia and Pacific & 3 \\
\hline 72 & Poland & Europe and Central Asia & 5 \\
\hline 73 & Portugal & OECD & Not applicable \\
\hline 74 & Qatar & Middle East and North Africa & 5 \\
\hline 75 & Rwanda & Sub-Saharan Africa & 1 \\
\hline 76 & Senegal & Sub-Saharan Africa & 2 \\
\hline 77 & Sierra Leone & Sub-Saharan Africa & 1 \\
\hline 78 & Singapore & East Asia and Pacific & 5 \\
\hline 79 & South Africa & Sub-Saharan Africa & 4 \\
\hline 80 & Spain & OECD & Not applicable \\
\hline 81 & Sri Lanka & South Asia & 3 \\
\hline 82 & Sudan & Sub-Saharan Africa & 2 \\
\hline 83 & Sweden & OECD & Not applicable \\
\hline 84 & Switzerland & OECD & Not applicable \\
\hline 85 & Tanzania & Sub-Saharan Africa & 1 \\
\hline 86 & Thailand & East Asia and Pacific & 4 \\
\hline 87 & Togo & Sub-Saharan Africa & 1 \\
\hline 88 & Tunisia & Middle East and North Africa & 3 \\
\hline 89 & Turkey & Europe and Central Asia & 5 \\
\hline 90 & Uganda & Sub-Saharan Africa & 1 \\
\hline 91 & United Kingdom & OECD & Not applicable \\
\hline 92 & United States & OECD & Not applicable \\
\hline 93 & Uruguay & Latin America and Caribbean & 5 \\
\hline 94 & Vietnam & East Asia and Pacific & 2 \\
\hline 95 & Zambia & Sub-Saharan Africa & 2 \\
\hline 96 & Zimbabwe & Sub-Saharan Africa & 2 \\
\hline
\end{tabular}




\section{Appendix C. Average Values of the Determinant Indexes and Their Indicators Over 1985-2014.}

Table C.1 shows the average values of the rescaled subcomponent and overall determinant indexes from 1 (the worst) to 100 (the best) and their indicators over 1985-2014. The individual indicators are shown without any transformation or standardization. Missing indicators are imputed if eligible as described in the section 3.3.

Table C.1

TFP determinant indexes and their indicators for OECD countries (21) and non-OECD countries (115), average (standard deviation), 1985-2014.

\begin{tabular}{|c|c|c|c|c|c|c|c|}
\hline & \multirow[t]{2}{*}{ OECD } & \multicolumn{6}{|c|}{ Non-OECD by region } \\
\hline & & $\begin{array}{l}\text { East } \\
\text { Asia and } \\
\text { Pacific }\end{array}$ & $\begin{array}{l}\text { Europe } \\
\text { and } \\
\text { Central } \\
\text { Asia }\end{array}$ & $\begin{array}{l}\text { Latin } \\
\text { America } \\
\text { and } \mathrm{Ca}- \\
\text { ribbean }\end{array}$ & $\begin{array}{l}\text { Middle } \\
\text { East and } \\
\text { North } \\
\text { Africa }\end{array}$ & $\begin{array}{l}\text { South } \\
\text { Asia }\end{array}$ & $\begin{array}{l}\text { Sub- } \\
\text { Saharan } \\
\text { Africa }\end{array}$ \\
\hline Overall determinant index & $\begin{array}{l}74.38 \\
(11.66)\end{array}$ & $\begin{array}{l}35.87 \\
(21.91)\end{array}$ & $\begin{array}{l}41.13 \\
(11.85)\end{array}$ & $\begin{array}{l}32.10 \\
(9.00)\end{array}$ & $\begin{array}{l}35.55 \\
(14.52)\end{array}$ & $\begin{array}{l}20.76 \\
(6.62)\end{array}$ & $\begin{array}{l}18.16 \\
(7.79)\end{array}$ \\
\hline I. Innovation index & $\begin{array}{l}37.49 \\
(16.06)\end{array}$ & $\begin{array}{l}11.95 \\
(19.73)\end{array}$ & $\begin{array}{l}9.45 \\
(7.19)\end{array}$ & $\begin{array}{l}4.46 \\
(2.80)\end{array}$ & $\begin{array}{l}12.32 \\
(15.85)\end{array}$ & $\begin{array}{l}3.59 \\
(2.00)\end{array}$ & $\begin{array}{l}3.74 \\
(1.62)\end{array}$ \\
\hline $\begin{array}{l}\text { Research and development ex- } \\
\text { penditure ( } \% \text { of GDP) }\end{array}$ & $\begin{array}{l}1.85 \\
(0.85)\end{array}$ & $\begin{array}{l}0.50 \\
(0.76)\end{array}$ & $\begin{array}{l}0.53 \\
(0.40)\end{array}$ & $\begin{array}{l}0.26 \\
(0.22)\end{array}$ & $\begin{array}{l}0.70 \\
(0.88)\end{array}$ & $\begin{array}{l}0.28 \\
(0.21)\end{array}$ & $\begin{array}{l}0.29 \\
(0.14)\end{array}$ \\
\hline $\begin{array}{l}\text { Number of patents (per } 100 \text { peo- } \\
\text { ple) }\end{array}$ & $\begin{array}{l}0.13 \\
(0.14)\end{array}$ & $\begin{array}{l}0.08 \\
(0.16)\end{array}$ & $\begin{array}{l}0.03 \\
(0.02)\end{array}$ & $\begin{array}{l}0.01 \\
(0.01)\end{array}$ & $\begin{array}{l}0.05 \\
(0.08)\end{array}$ & $\begin{array}{l}0.00 \\
(0.00)\end{array}$ & $\begin{array}{l}0.00 \\
(0.01)\end{array}$ \\
\hline $\begin{array}{l}\text { Number of journal articles (per } \\
100 \text { people) }\end{array}$ & $\begin{array}{l}0.09 \\
(0.05)\end{array}$ & $\begin{array}{l}0.01 \\
(0.04)\end{array}$ & $\begin{array}{l}0.02 \\
(0.03)\end{array}$ & $\begin{array}{l}0.00 \\
(0.01)\end{array}$ & $\begin{array}{l}0.02 \\
(0.03)\end{array}$ & $\begin{array}{l}0.00 \\
(0.00)\end{array}$ & $\begin{array}{l}0.00 \\
(0.00)\end{array}$ \\
\hline II. Education index & $\begin{array}{l}61.12 \\
(12.88)\end{array}$ & $\begin{array}{l}33.62 \\
(22.01)\end{array}$ & $\begin{array}{l}49.87 \\
(12.10)\end{array}$ & $\begin{array}{l}31.54 \\
(10.69)\end{array}$ & $\begin{array}{l}33.47 \\
(12.48)\end{array}$ & $\begin{array}{l}18.88 \\
(8.05)\end{array}$ & $\begin{array}{l}15.28 \\
(7.82)\end{array}$ \\
\hline $\begin{array}{l}\text { Government expenditure on } \\
\text { education, total ( } \% \text { of GDP) }\end{array}$ & $\begin{array}{l}5.21 \\
(1.15)\end{array}$ & $\begin{array}{l}3.11 \\
(1.38)\end{array}$ & $\begin{array}{l}4.19 \\
(1.24)\end{array}$ & $\begin{array}{l}3.83 \\
(1.80)\end{array}$ & $\begin{array}{l}4.83 \\
(1.93)\end{array}$ & $\begin{array}{l}2.75 \\
(0.81)\end{array}$ & $\begin{array}{l}4.02 \\
(2.54)\end{array}$ \\
\hline $\begin{array}{l}\text { Percentage of population aged } \\
25-64 \text { with completed secondary } \\
\text { schooling }\end{array}$ & $\begin{array}{l}30.10 \\
(11.93)\end{array}$ & $\begin{array}{l}16.96 \\
(12.49)\end{array}$ & $\begin{array}{l}42.78 \\
(16.05)\end{array}$ & $\begin{array}{l}16.91 \\
(7.93)\end{array}$ & $\begin{array}{l}16.61 \\
(8.74)\end{array}$ & $\begin{array}{l}12.69 \\
(9.97)\end{array}$ & $\begin{array}{l}7.42 \\
(7.08)\end{array}$ \\
\hline $\begin{array}{l}\text { Percentage of population aged } \\
25-64 \text { with completed tertiary } \\
\text { schooling }\end{array}$ & $\begin{array}{l}14.06 \\
(6.42)\end{array}$ & $\begin{array}{l}6.90 \\
(7.65)\end{array}$ & $\begin{array}{l}10.17 \\
(4.77)\end{array}$ & $\begin{array}{l}7.10 \\
(4.55)\end{array}$ & $\begin{array}{l}7.39 \\
(6.01)\end{array}$ & $\begin{array}{l}4.20 \\
(2.17)\end{array}$ & $\begin{array}{l}1.17 \\
(0.84)\end{array}$ \\
\hline $\begin{array}{l}\text { PISA, average of math, science, } \\
\text { and reading }\end{array}$ & $\begin{array}{l}503.47 \\
(21.43)\end{array}$ & $\begin{array}{l}438.37 \\
(76.21)\end{array}$ & $\begin{array}{l}427.63 \\
(44.57)\end{array}$ & $\begin{array}{l}408.83 \\
(25.57)\end{array}$ & $\begin{array}{l}405.57 \\
(30.81)\end{array}$ & $\begin{array}{l}370.94 \\
(14.62)\end{array}$ & $\begin{array}{l}368.65 \\
(2.82) \\
\end{array}$ \\
\hline III. Market efficiency index & $\begin{array}{l}82.94 \\
(9.90)\end{array}$ & $\begin{array}{l}54.04 \\
(19.74)\end{array}$ & $\begin{array}{l}52.06 \\
(12.42)\end{array}$ & $\begin{array}{l}47.12 \\
(10.67)\end{array}$ & $\begin{array}{l}45.67 \\
(14.09)\end{array}$ & $\begin{array}{l}38.55 \\
(5.92)\end{array}$ & $\begin{array}{l}34.47 \\
(12.49)\end{array}$ \\
\hline $\begin{array}{l}\text { a. World Bank Doing Business } \\
\text { scores }\end{array}$ & $\begin{array}{l}72.37 \\
(9.61)\end{array}$ & $\begin{array}{l}48.02 \\
(19.82)\end{array}$ & $\begin{array}{l}45.33 \\
(18.13)\end{array}$ & $\begin{array}{l}44.14 \\
(14.21)\end{array}$ & $\begin{array}{l}43.33 \\
(15.88)\end{array}$ & $\begin{array}{l}38.45 \\
(13.60)\end{array}$ & $\begin{array}{l}31.87 \\
(15.26)\end{array}$ \\
\hline $\begin{array}{l}\text { b. IMF Financial Development } \\
\text { Index }\end{array}$ & $\begin{array}{l}0.66 \\
(0.16)\end{array}$ & $\begin{array}{l}0.34 \\
(0.24)\end{array}$ & $\begin{array}{l}0.20 \\
(0.15)\end{array}$ & $\begin{array}{l}0.22 \\
(0.11)\end{array}$ & $\begin{array}{l}0.29 \\
(0.14)\end{array}$ & $\begin{array}{l}0.22 \\
(0.09)\end{array}$ & $\begin{array}{l}0.11 \\
(0.08)\end{array}$ \\
\hline c. Labor market index & $\begin{array}{l}-0.92 \\
(0.37)\end{array}$ & $\begin{array}{l}0.01 \\
(0.87)\end{array}$ & $\begin{array}{l}-0.67 \\
(0.48)\end{array}$ & $\begin{array}{l}0.13 \\
(0.54)\end{array}$ & $\begin{array}{l}0.64 \\
(0.83)\end{array}$ & $\begin{array}{l}0.99 \\
(0.46)\end{array}$ & $\begin{array}{l}0.58 \\
(1.17)\end{array}$ \\
\hline $\begin{array}{l}\text { - Ratio of minimum wage to va- } \\
\text { lue added per worker }\end{array}$ & $\begin{array}{l}0.25 \\
(0.14)\end{array}$ & $\begin{array}{l}0.35 \\
(0.26)\end{array}$ & $\begin{array}{l}0.29 \\
(0.13)\end{array}$ & $\begin{array}{l}0.56 \\
(0.39)\end{array}$ & $\begin{array}{l}0.45 \\
(0.41)\end{array}$ & $\begin{array}{l}0.38 \\
(0.33)\end{array}$ & $\begin{array}{l}0.64 \\
(0.56)\end{array}$ \\
\hline $\begin{array}{l}\text { - Severance pay for redundancy } \\
\text { dismissal (weeks of salary) }\end{array}$ & $\begin{array}{l}4.33 \\
(5.81)\end{array}$ & $\begin{array}{l}20.26 \\
(15.25)\end{array}$ & $\begin{array}{l}8.74 \\
(4.59)\end{array}$ & $\begin{array}{l}17.72 \\
(7.73)\end{array}$ & $\begin{array}{l}14.12 \\
(9.70)\end{array}$ & $\begin{array}{l}25.89 \\
(13.58)\end{array}$ & $\begin{array}{l}14.52 \\
(16.67)\end{array}$ \\
\hline
\end{tabular}

(Continued on next page) 
Table C.1 (continued)

\begin{tabular}{|c|c|c|c|c|c|c|c|}
\hline & \multirow[t]{2}{*}{ OECD } & \multicolumn{6}{|c|}{ Non-OECD by region } \\
\hline & & $\begin{array}{l}\text { East } \\
\text { Asia and } \\
\text { Pacific }\end{array}$ & $\begin{array}{l}\text { Europe } \\
\text { and } \\
\text { Central } \\
\text { Asia }\end{array}$ & $\begin{array}{l}\text { Latin } \\
\text { America } \\
\text { and Ca- } \\
\text { ribbean }\end{array}$ & $\begin{array}{l}\text { Middle } \\
\text { East and } \\
\text { North } \\
\text { Africa }\end{array}$ & $\begin{array}{l}\text { South } \\
\text { Asia }\end{array}$ & $\begin{array}{l}\text { Sub- } \\
\text { Saharan } \\
\text { Africa }\end{array}$ \\
\hline $\begin{array}{l}\text { - Share of women in wage em- } \\
\text { ployment in the nonagricultural } \\
\text { sector ( } \% \text { of total nonagricultu- } \\
\text { ral employment) }\end{array}$ & $\begin{array}{l}45.37 \\
(4.39)\end{array}$ & $\begin{array}{l}39.52 \\
(5.50)\end{array}$ & $\begin{array}{l}44.23 \\
(8.35)\end{array}$ & $\begin{array}{l}40.10 \\
(5.47)\end{array}$ & $\begin{array}{l}20.25 \\
(10.64)\end{array}$ & $\begin{array}{l}20.47 \\
(7.12)\end{array}$ & $\begin{array}{l}27.74 \\
(10.74)\end{array}$ \\
\hline IV. Infrastructure index & $\begin{array}{l}71.55 \\
(9.53)\end{array}$ & $\begin{array}{l}33.55 \\
(16.91)\end{array}$ & $\begin{array}{l}47.64 \\
(10.39)\end{array}$ & $\begin{array}{l}36.80 \\
(9.50)\end{array}$ & $\begin{array}{l}42.24 \\
(12.60)\end{array}$ & $\begin{array}{l}24.04 \\
(8.77)\end{array}$ & $\begin{array}{l}18.94 \\
(7.37)\end{array}$ \\
\hline $\begin{array}{l}\text { Fixed telephone subscriptions } \\
\text { (per } 100 \text { people) }\end{array}$ & $\begin{array}{l}48.40 \\
(10.77)\end{array}$ & $\begin{array}{l}13.76 \\
(18.29)\end{array}$ & $\begin{array}{l}18.81 \\
(10.67)\end{array}$ & $\begin{array}{l}11.05 \\
(8.13)\end{array}$ & $\begin{array}{l}14.04 \\
(12.30)\end{array}$ & $\begin{array}{l}2.04 \\
(3.25)\end{array}$ & $\begin{array}{l}1.21 \\
(1.99)\end{array}$ \\
\hline $\begin{array}{l}\text { Mobile cellular subscriptions } \\
\text { (per } 100 \text { people) }\end{array}$ & $\begin{array}{l}53.97 \\
(49.71)\end{array}$ & $\begin{array}{l}33.76 \\
(49.96)\end{array}$ & $\begin{array}{l}37.77 \\
(49.52)\end{array}$ & $\begin{array}{l}31.96 \\
(44.52)\end{array}$ & $\begin{array}{l}34.36 \\
(45.99)\end{array}$ & $\begin{array}{l}15.78 \\
(26.73)\end{array}$ & $\begin{array}{l}15.21 \\
(28.23)\end{array}$ \\
\hline $\begin{array}{l}\text { Electricity production }(\mathrm{kWh} \text { per } \\
100 \text { people) }\end{array}$ & $\begin{array}{l}932462.60 \\
(559809.30)\end{array}$ & $\begin{array}{l}199921.20 \\
(251765.20)\end{array}$ & $\begin{array}{l}355155.10 \\
(167625.10)\end{array}$ & $\begin{array}{l}174065.30 \\
(173809.20)\end{array}$ & $\begin{array}{l}356559.90 \\
(456594.60)\end{array}$ & $\begin{array}{l}28440.79 \\
(21837.76)\end{array}$ & $\begin{array}{l}35189.09 \\
(80191.89)\end{array}$ \\
\hline Paved roads (km per 100 people) & $\begin{array}{l}1.20 \\
(0.48)\end{array}$ & $\begin{array}{l}0.07 \\
(0.07)\end{array}$ & $\begin{array}{l}0.51 \\
(0.37)\end{array}$ & $\begin{array}{l}0.14 \\
(0.15)\end{array}$ & $\begin{array}{l}0.17 \\
(0.07)\end{array}$ & $\begin{array}{l}0.11 \\
(0.13)\end{array}$ & $\begin{array}{l}0.06 \\
(0.08)\end{array}$ \\
\hline $\begin{array}{l}\text { Improved sanitation facilities } \\
\text { ( } \% \text { of population with access) }\end{array}$ & $\begin{array}{l}98.48 \\
(2.51)\end{array}$ & $\begin{array}{l}62.70 \\
(30.08)\end{array}$ & $\begin{array}{l}88.30 \\
(10.93)\end{array}$ & $\begin{array}{l}71.56 \\
(19.84)\end{array}$ & $\begin{array}{l}82.82 \\
(17.96)\end{array}$ & $\begin{array}{l}38.58 \\
(23.20)\end{array}$ & $\begin{array}{l}24.55 \\
(15.58)\end{array}$ \\
\hline $\begin{array}{l}\text { Improved water source ( } \% \text { of po- } \\
\text { pulation with access) }\end{array}$ & $\begin{array}{l}99.60 \\
(0.96)\end{array}$ & $\begin{array}{l}74.15 \\
(22.66)\end{array}$ & $\begin{array}{l}91.02 \\
(11.69)\end{array}$ & $\begin{array}{l}85.85 \\
(10.22)\end{array}$ & $\begin{array}{l}89.76 \\
(12.24)\end{array}$ & $\begin{array}{l}71.65 \\
(20.94)\end{array}$ & $\begin{array}{l}59.81 \\
(17.14)\end{array}$ \\
\hline V. Institutions index & $\begin{array}{l}89.37 \\
(7.19)\end{array}$ & $\begin{array}{l}54.84 \\
(17.71)\end{array}$ & $\begin{array}{l}51.30 \\
(15.58)\end{array}$ & $\begin{array}{l}54.15 \\
(12.67)\end{array}$ & $\begin{array}{l}52.73 \\
(12.22)\end{array}$ & $\begin{array}{l}41.83 \\
(12.48)\end{array}$ & $\begin{array}{l}43.90 \\
(13.32)\end{array}$ \\
\hline Voice and accountability & $\begin{array}{l}1.39 \\
(0.22)\end{array}$ & $\begin{array}{l}-0.46 \\
(0.85)\end{array}$ & $\begin{array}{l}-0.23 \\
(0.89)\end{array}$ & $\begin{array}{l}0.03 \\
(0.67)\end{array}$ & $\begin{array}{l}-0.64 \\
(0.53)\end{array}$ & $\begin{array}{l}-0.58 \\
(0.70)\end{array}$ & $\begin{array}{l}-0.70 \\
(0.71)\end{array}$ \\
\hline Control of corruption & $\begin{array}{l}1.76 \\
(0.61)\end{array}$ & $\begin{array}{l}-0.16 \\
(1.01)\end{array}$ & $\begin{array}{l}-0.47 \\
(0.66)\end{array}$ & $\begin{array}{l}-0.27 \\
(0.72)\end{array}$ & $\begin{array}{l}-0.12 \\
(0.69)\end{array}$ & $\begin{array}{l}-0.77 \\
(0.55)\end{array}$ & $\begin{array}{l}-0.59 \\
(0.65)\end{array}$ \\
\hline Government effectiveness & $\begin{array}{l}1.69 \\
(0.44)\end{array}$ & $\begin{array}{l}0.02 \\
(0.94)\end{array}$ & $\begin{array}{l}-0.35 \\
(0.74)\end{array}$ & $\begin{array}{l}-0.20 \\
(0.64)\end{array}$ & $\begin{array}{l}-0.06 \\
(0.70)\end{array}$ & $\begin{array}{l}-0.67 \\
(0.65)\end{array}$ & $\begin{array}{l}-0.70 \\
(0.63)\end{array}$ \\
\hline Political stability & $\begin{array}{l}1.05 \\
(0.42)\end{array}$ & $\begin{array}{l}-0.21 \\
(0.92)\end{array}$ & $\begin{array}{l}-0.25 \\
(0.86)\end{array}$ & $\begin{array}{l}-0.34 \\
(0.66)\end{array}$ & $\begin{array}{l}-0.50 \\
(0.95)\end{array}$ & $\begin{array}{l}-1.45 \\
(0.72)\end{array}$ & $\begin{array}{l}-0.71 \\
(1.02)\end{array}$ \\
\hline Regulatory quality & $\begin{array}{l}1.42 \\
(0.38)\end{array}$ & $\begin{array}{l}-0.02 \\
(1.06)\end{array}$ & $\begin{array}{l}-0.22 \\
(0.89)\end{array}$ & $\begin{array}{l}0.05 \\
(0.73)\end{array}$ & $\begin{array}{l}-0.21 \\
(0.74)\end{array}$ & $\begin{array}{l}-0.72 \\
(0.71)\end{array}$ & $\begin{array}{l}-0.65 \\
(0.66)\end{array}$ \\
\hline Rule of law & $\begin{array}{l}1.54 \\
(0.35)\end{array}$ & $\begin{array}{l}-0.17 \\
(0.87)\end{array}$ & $\begin{array}{l}-0.46 \\
(0.78)\end{array}$ & $\begin{array}{l}-0.46 \\
(0.71)\end{array}$ & $\begin{array}{l}-0.08 \\
(0.67)\end{array}$ & $\begin{array}{l}-0.59 \\
(0.72)\end{array}$ & $\begin{array}{l}-0.77 \\
(0.68)\end{array}$ \\
\hline
\end{tabular}

\section{Appendix D. Regression with Different Time-Lags for Robustness Check}

We run regressions with different time lags of 3 and 7 years for a robustness check of the fixed-effect model. Table D.1 shows that the sign and the significance of coefficients under the models using 3- and 7-year lags are consistent with those using 5-year lags. 
Table D.1

Regression with different time lags.

\begin{tabular}{|c|c|c|c|}
\hline Dependent variable: & \multicolumn{3}{|c|}{ annualized TFP growth gr, $(t-\alpha, t)$} \\
\hline Number of observations: & 869 & 477 & 379 \\
\hline Number of groups (countries): & 98 & 98 & 98 \\
\hline Time lag (a): & 3 years & 5 years & 7 years \\
\hline \multirow[t]{3}{*}{ Regressors (below): } & Coefficient (SE) & Coefficient (SE) & Coefficient (SE) \\
\hline & $0.039(0.0138) * * *$ & $0.050(0.0183) * * *$ & $0.025(0.0074) * * *$ \\
\hline & $-0.120(0.0119) * * *$ & $-0.099(0.0151) * * *$ & $-0.102(0.0100) * * *$ \\
\hline Constant & $-0.143(0.0470) * * *$ & $-0.180(0.0636) * * *$ & $-0.094(0.0244) * * *$ \\
\hline \multicolumn{4}{|l|}{$R^{2}:$} \\
\hline Within & 0.2729 & 0.3048 & 0.4535 \\
\hline Between & 0.2669 & 0.2749 & 0.6002 \\
\hline Overall & 0.1457 & 0.1586 & 0.3841 \\
\hline
\end{tabular}

Note: $\mathrm{SE}=$ Standard error; $*$ : significant at $10 \% ; * *$ : significant at $5 \% ; * * *$ : significant at $1 \%$ level. The coefficients of time dummies are not listed.

\section{Appendix E. Robustness Check Using World Development Indicators for TFP Calculation}

As a robustness check, we obtain results using World Development Indicators (WDI) as a primary source for TFP calculations and compare them with those presented in the main text, which use PWT 9.0 as primary data. Specifically, we use WDI for real GDP, capital formation, population, and employment rate (World Bank, 2017b,d,g,m,n) and the PWT 9.0 (Feenstra et al., 2015) and GTAP 9.0 for country- and time-specific labor shares. Because the employment rate in WDI is available from 1991 and onward, we impute missing values for 1985-90 applying the annual change of the employment rate in PWT. To calculate the physical capital stock, we use the perpetual inventory method (Barro and Sala-I-Martin, 2004) with a depreciation rate of $4 \%$ and an initial year of 1960 or the earliest year with available data. The list of countries included in the analysis using the WDI data set is presented in Table B.1.

\section{1) Total Factor Productivity}

Figure E.1 shows the trend of average annual TFP growth rate over decades calculated using PWT 9.0 and WDI as primary sources.

The results from the two sources are similar in terms of signs and magnitude for the period 1985-2004 for all, OECD, and developing countries. For the period 2004-14, the average TFP growth rate calculated using WDI is much lower than that using PWT, especially for the developing countries. This is driven by the gap in the average TFP growth rate between the two sources for Europe and Central Asia and Sub-Saharan African for the recent decade as shown in Figure E.2. For Europe and Central Asia, WDI has missing values for several countries unlike PWT. For Sub-Saharan Africa, some countries such as Mozambique and Zimbabwe have quite low average TFP growth rates (less than -3 percent). 


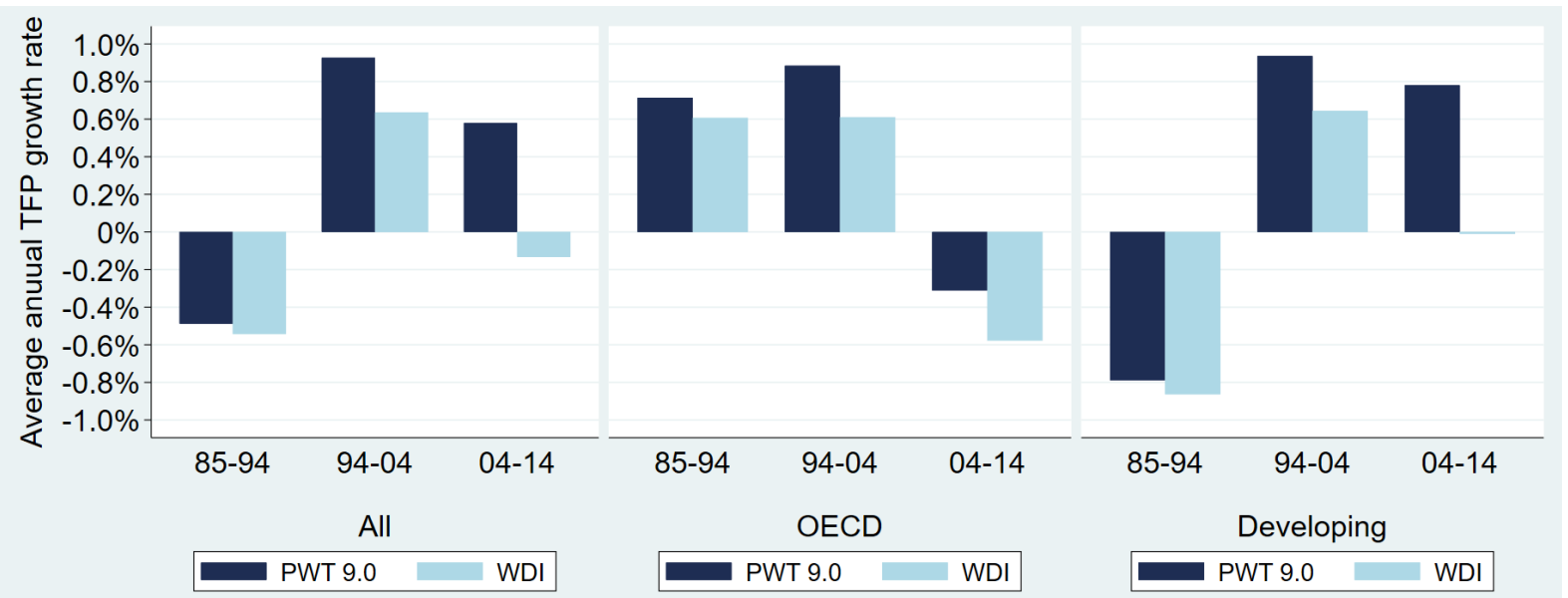

Source: Authors' calculation, using PWT 9.0, GTAP (for a few cases), and WDI data.

Note: The OECD group includes high-income countries that have been members of OECD for more than 40 years.

Figure E.1. Comparison of average annual TFP growth rates using PWT 9.0 and WDI for all, OECD, and developing countries.

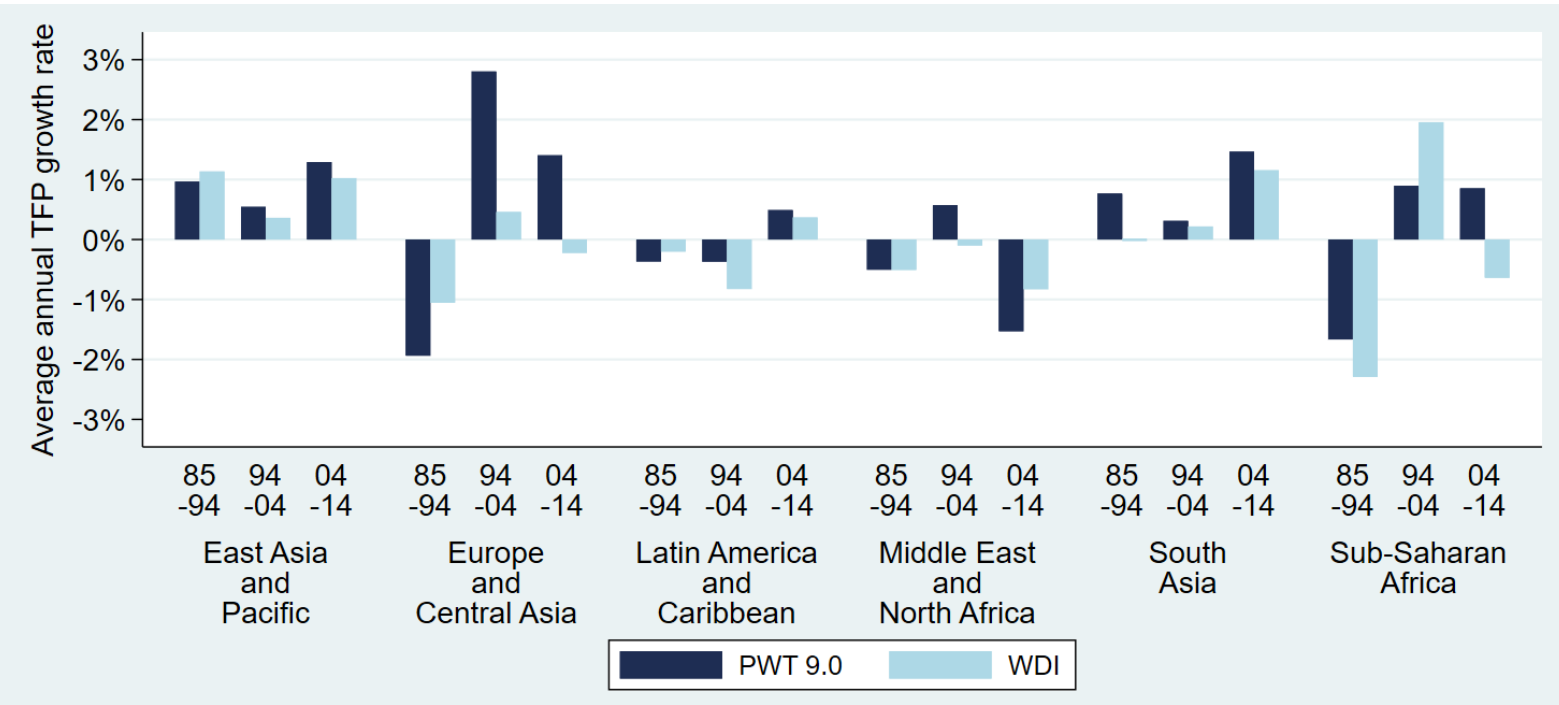

Source: Authors' calculation, using PWT 9.0, GTAP (for a few cases), and WDI data.

Figure E.2. Comparison of average annual TFP growth rates using PWT 9.0 and WDI for developing countries by region.

Figure E.3 shows the comparison of average annual TFP growth rates weighted by real GDP using PWT 9.0 and WDI. The results are similar in terms of signs. However, the magnitude tends to be bigger when WDI is used as the primary source for East Asia and Pacific, Latin America and Caribbean, and Sub-Saharan Africa. 


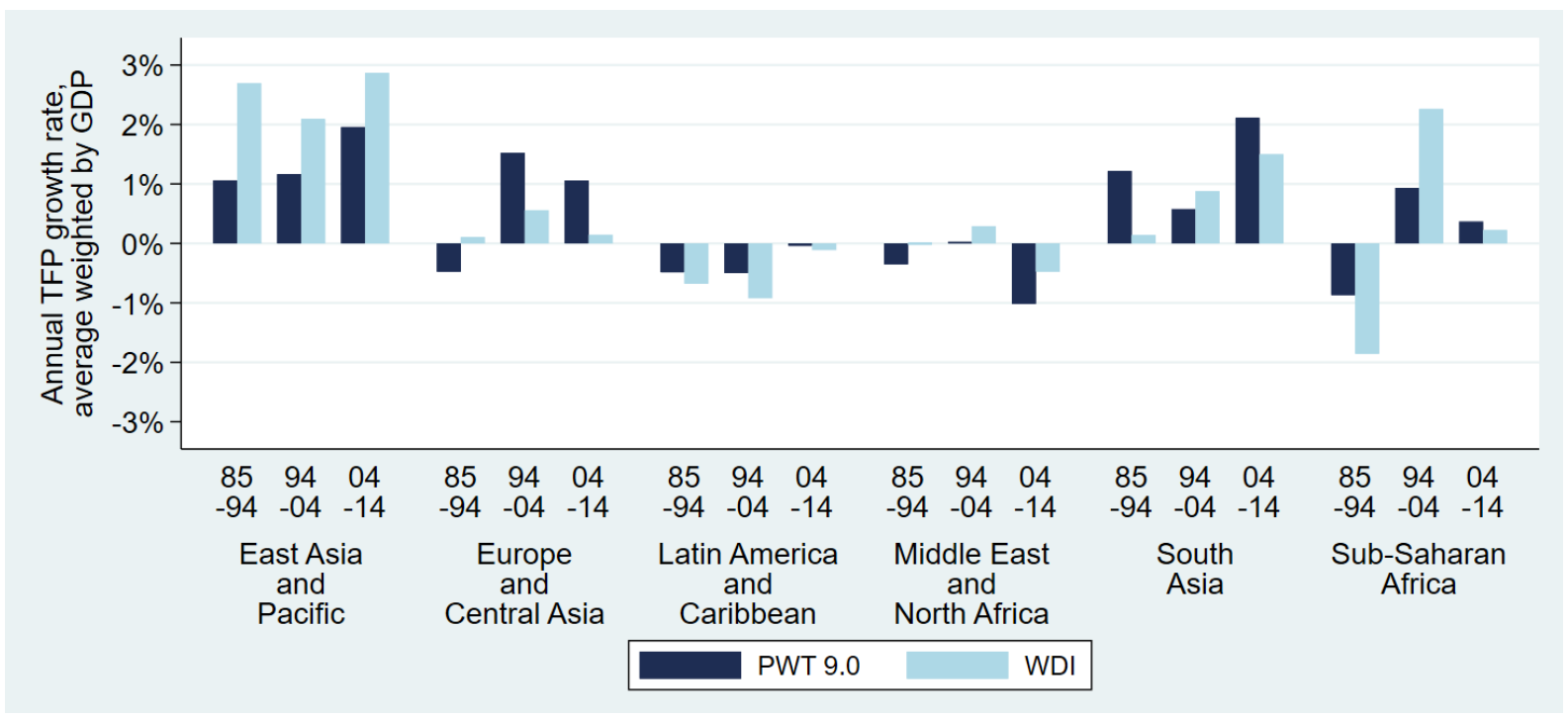

Source: Authors' calculation, using PWT 9.0, GTAP (for a few cases), and WDI data.

Figure E.3. Comparison of average annual TFP growth rate weighted by real GDP using PWT 9.0 and WDI for developing countries by region.

2) Statistical Analysis

The relative contribution of the main determinants to total factor productivity

We conduct the variance decomposition of TFP growth rates using PWT 9.0 and WDI as primary sources and compare the results. The list of developing countries with available TFP growth rates is different between PWT 9.0 and WDI; therefore, we conduct the analysis for the full sample of countries for each source and for the common sample (60 developing and 21 OECD countries). Figure E.4 shows, for the OECD group, the largest contributor is market efficiency using PWT 9.0 and innovation using WDI for the recent decade, and the smallest contributor is infrastructure using the both data sources. For the developing countries, the largest contributor is institutions in the period 1985-94; however, in the period 2004-14, it varies among education, market efficiency, and institutions depending on a set of countries and data sources. The common feature among the four sets of results for the developing countries is that innovation and infrastructure have a lower contribution compared to other determinants in the last decade.

The relationship between the overall determinant index and total factor productivity

We run regressions for the same model (equation (2)) using PWT 9.0 and WDI as primary sources and compare results. The list of countries with available TFP growth rates is different between PWT 9.0 and WDI; therefore, we run regressions for the full sample of countries for each source and the common sample (81 countries).

For the pooled OLS, random-effect, and fixed-effect models, shown in table E.1-E.3 respectively, the results are consistent in terms of sign and significance between PWT 9.0 and WDI for 


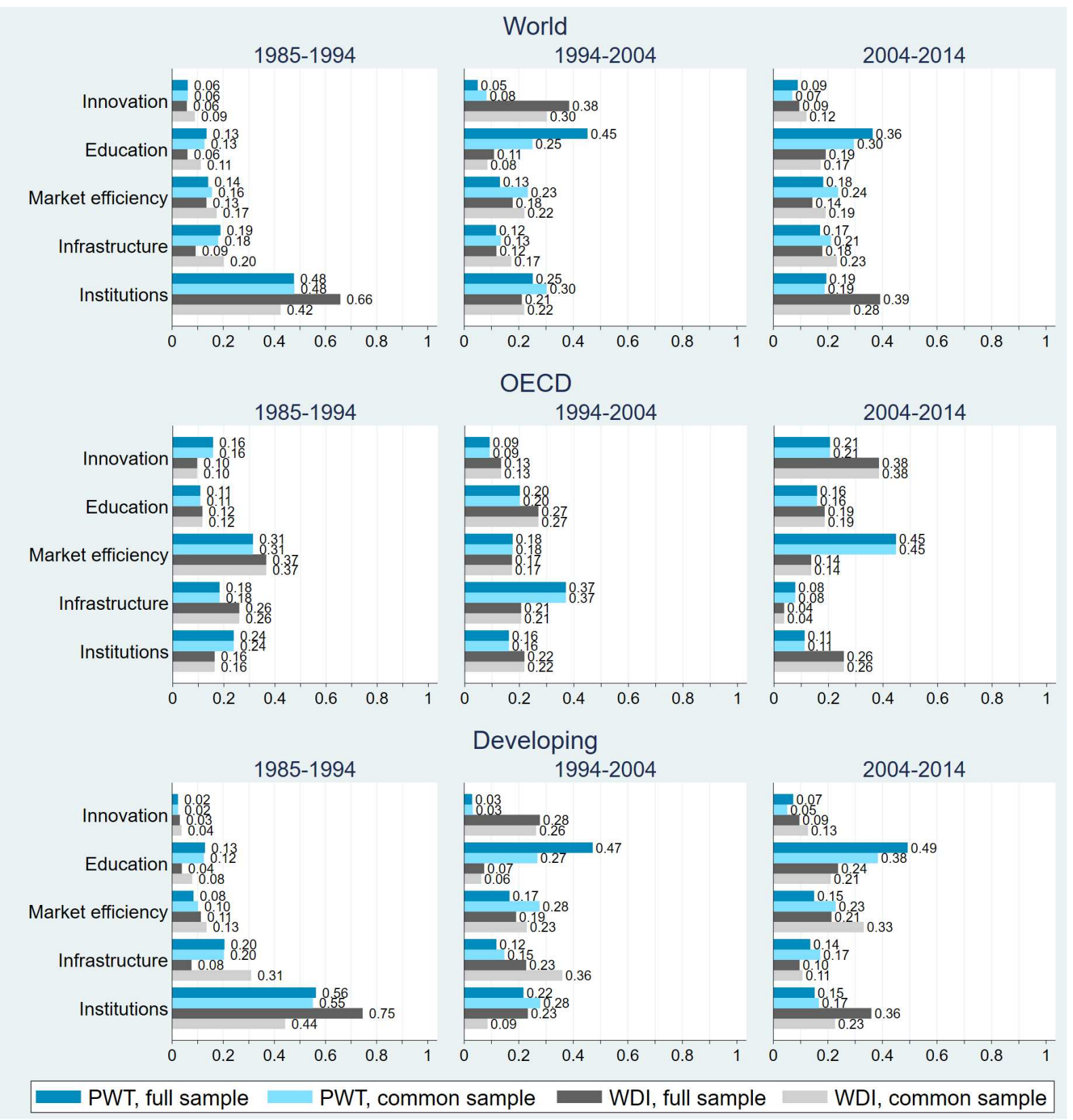

Source: Authors' calculation.

Note: The OECD group includes high-income countries that have been members of OECD for more than 40 years.

Figure E.4. Comparison of the variance decomposition of TFP growth rates into the determinant indexes using PWT 9.0 and WDI by decade for all, OECD, and developing countries, controlling for the TFP level lagged by five years and time-effects.

the full and the common sample of countries. These results suggest that the fixed-effect model with the five-year lag fitted to the full sample of PWT 9.0, the model we choose for simulation and the extended LTGM, is robust. 
Table E.1

Comparison of the regression results using PWT 9.0 and WDI, pooled OLS.

\begin{tabular}{|c|c|c|c|c|}
\hline \multirow{3}{*}{$\begin{array}{l}\text { Dependent variable: } \\
\text { Country effects: } \\
\text { Primary source: }\end{array}$} & \multicolumn{4}{|c|}{ annualized TFP growth $h_{c,(t-\alpha, t)}$} \\
\hline & None (pooled OLS) & & & \\
\hline & PWT 9.0 & & WDI & \\
\hline Number of observations: & 477 & 400 & 468 & 394 \\
\hline Number of groups (countries): & 98 & 81 & 96 & 81 \\
\hline Country sample: & Full & Common & Full & Common \\
\hline $\ln \left(\right.$ Index $\left._{c, t-5}\right)$ & $0.004(0.0011) * * *$ & $0.004(0.0012) * * *$ & $0.006(0.0023) * *$ & $0.004(0.0013) * * *$ \\
\hline $\ln (T F P \text { level })_{c, t-5}$ & $-0.082(0.0052) * * *$ & $-0.087(0.0076) * * *$ & $-0.089(0.0189) * * *$ & $-0.070(0.0063) * * *$ \\
\hline Constant & $-0.021(0.0055) * *$ & $-0.020(0.0062) * * *$ & $-0.030(0.0113) * * *$ & $-0.019(0.0062) * * *$ \\
\hline$R^{2}:$ & 0.4022 & 0.3564 & 0.4260 & 0.4073 \\
\hline
\end{tabular}

Note: Results are expressed as coefficient (standard error).

*: significant at $10 \% ; * *$ : significant at $5 \% ; * * *$ : significant at $1 \%$ level.

The coefficients of time dummies are not listed. We use country-cluster robust variance estimation.

Table E.2

Comparison of the regression results using PWT 9.0 and WDI, random effect.

\begin{tabular}{|c|c|c|c|c|}
\hline \multirow{2}{*}{ Dependent variable: } & \multicolumn{4}{|c|}{ annualized TFP growth $_{c,(t-\alpha, t)}$} \\
\hline & Random & & & \\
\hline Primary source: & PWT 9.0 & & WDI & \\
\hline Number of observations: & 477 & 400 & 468 & 394 \\
\hline Number of groups (countries): & 98 & 81 & 96 & 81 \\
\hline Country sample: & Full & Common & Full & Common \\
\hline $\ln \left(\right.$ Index $\left._{c, t-5}\right)$ & $0.004(0.0011) * * *$ & $0.004(0.0012) * * *$ & $0.006(0.0023) * * *$ & $0.004(0.0013) * * *$ \\
\hline $\ln (T F P \text { level })_{c, t-5}$ & $-0.082(0.0052) * * *$ & $-0.087(0.0076) * * *$ & $-0.089(0.0189) * * *$ & $-0.070(0.0063) * * *$ \\
\hline $\begin{array}{l}\text { Constant } \\
R^{2} \text { : }\end{array}$ & $-0.021(0.0055) * * *$ & $-0.020(0.0062) * * *$ & $-0.030(0.0113) * * *$ & $-0.019(0.0062) * * *$ \\
\hline Within & 0.2784 & 0.3245 & 0.4003 & 0.2158 \\
\hline Between & 0.8573 & 0.7482 & 0.4639 & 0.4779 \\
\hline Overall & 0.4022 & 0.3564 & 0.4260 & 0.4073 \\
\hline
\end{tabular}

Note: Results are expressed as coefficient (standard error).

*: significant at $10 \%$;*: significant at $5 \%$; $* *$ : significant at $1 \%$ level.

The coefficients of time dummies are not listed.

Table E.3

Comparison of the regression results using PWT 9.0 and WDI, fixed effect.

\begin{tabular}{|c|c|c|c|c|}
\hline \multirow{2}{*}{$\begin{array}{l}\text { Dependent variable: } \\
\text { Country effects: }\end{array}$} & \multicolumn{4}{|c|}{ annualized TFP growth $_{c,(t-\alpha, t)}$} \\
\hline & Fixed & & & \\
\hline Primary source: & PWT 9.0 & & WDI & \\
\hline Number of observations: & 477 & 400 & 468 & 394 \\
\hline Number of groups (countries): & 98 & 81 & 96 & 81 \\
\hline Country sample: & Full & Common & Full & Common \\
\hline $\ln \left(\right.$ Index $\left._{c, t-5}\right)$ & $0.050(0.0183) * * *$ & $0.055(0.0197) * * *$ & $0.098(0.0268) * * *$ & $0.062(0.0233) * * *$ \\
\hline $\ln (T F P \text { level })_{c, t-5}$ & $-0.099(0.0151) * * *$ & $-0.124(0.0171) * * *$ & $-0.116(0.0351) * * *$ & $-0.071(0.0143) * * *$ \\
\hline $\begin{array}{l}\text { Constant } \\
R^{2}:\end{array}$ & $-0.180(0.0636) * * *$ & $-0.198(0.0684) * * *$ & $-0.333(0.0894) * * *$ & $-0.219(0.0803) * * *$ \\
\hline Within & 0.3048 & 0.3660 & 0.505 & 0.2776 \\
\hline Between & 0.2749 & 0.2193 & 0.1499 & 0.1376 \\
\hline Overall & 0.1586 & 0.1238 & 0.1371 & 0.1089 \\
\hline
\end{tabular}

Note: Results are expressed as coefficient (standard error).

*: significant at $10 \% ; * *$ : significant at $5 \%$; **: significant at $1 \%$ level.

The coefficients of time dummies are not listed. 


\section{References}

Abdih, Y., and Joutz, F. (2006). Relating the Knowledge Production Function to Total Factor Productivity: An Endogenous Growth Puzzle. WP/05/74. IMF Working Paper.

Abramovitz, M. (1956). Resource and Output Trends in the United States since 1870. American Economic Review 46, 5-23.

Acemoglu, D., Johnson, S., and Robinson, J. (2004). Institutions as the Fundamental Cause of Long-Run Growth. 10481. NBER Working Paper.

Acemoglu, D., Johnson, S., and Robinson, J. (2001). The Colonial Origins of Comparative Development: An Empirical Investigation. American Economic Review 91(5), 1369-1401. https://doi.org/10.1257/aer.91.5.1369.

Acemoglu, D., and Zilibotti, F. (2001). Productivity Differences. Quarterly Journal of Economics 116(2), 563-606. https://doi.org/10.1162/00335530151144104.

Aghion, P., and Howitt, P. (1992). A Model of Growth through Creative Destruction. Econometrica 60(2), 323-51. https://doi.org/10.2307/2951599.

Aguiar, A., Narayanan, B., and McDougall, R. (2016). An Overview of the GTAP 9 Data Base. Journal of Global Economic Analysis 1(1), 181-208. https://doi.org/10.21642/JGEA.010103AF.

Alfaro, L., Chanda, A., Kalemli-Ozcan, S., and Sayek, S. (2004). FDI and Economic Growth: The Role of Local Financial Markets. Journal of International Economics 64(1), 89-112. https://doi.org/10.1016/S0022-1996(03)00081-3.

Alfaro, L., Kalemli-Ozcan, S., and Sayek, S. (2009). FDI, Productivity and Financial Development. World Economy 32(1), 111-35. https://doi.org/10.1111/j.1467-9701.2009.01159.x.

Arnold, J., Nicoletti, G., and Scarpetta, S. (2008). Regulation, Allocative Efficiency and Productivity in OECD Countries. 616. OECD Economics Department Working Papers. https://doi.org/10.1787/241447806226.

Aschauer, D. (1989). Is Public Expenditure Productive? Journal of Monetary Economics 23(2), 177-200. https://doi.org/10.1016/0304-3932(89)90047-0.

Azen, R., and Budescu, D. (2003). The Dominance Analysis Approach for Comparing Predictors in Multiple Regression. Psychological Methods 8(2), 129-48. https://doi.org/10.1037/1082989X.8.2.129.

Barro, R., and Lee, J. (2013). A New Data Set of Educational Attainment in the World, 1950-2010. Journal of Development Economics 104, 184-98. https://doi.org/10.1016/j.jdeveco.2012.10.001.

Barro, R., and Sala-I-Martin, X. (1992). Public Finance in Models of Economic Growth. The Review of Economic Studies 59(4), 645. https://doi.org/10.2307/2297991.

Barro, R., and Sala-i-Martin, X. (2004). Growth Accounting. In R. Barro and X. Sala-i-Martin (Eds.). Economic Growth, 2nd ed. Cambridge, Massachusetts: The MIT Press.

Barro, R. (1990). Government Spending in a Simple Model of Endogeneous Growth. Journal of Political Economy 98(5), S103-25. https://doi.org/10.1086/261726.

Barro, R. (1991). Economic Growth in a Cross-Section of Countries. The Quarterly Journal of 
Economics 106(2), 407-43. https://doi.org/10.2307/2937943.

Barro, R. (2001). Human Capital and Growth. The American Economic Review 91(2), 12-17. www.jstor.org/stable/2677725.

Bartelsman, E., Gautier, P., and Wind, J. (2016). Employment Protection, Technology Choice, and Worker Allocation. International Economic Review 57(3), 787-826. https://doi.org/10.1111/iere.12176.

Beck, T., Levine, R., and Loayza, N. (2000). Finance and the Sources of Growth. Journal of Financial Economics 58(1-2), 261-300. https://doi.org/10.1016/S0304-405X(00)00072-6.

Ben-David, D., and Papell, D. (1998). Slowdowns and Meltdowns: Postwar Growth Evidence from 74 Countries. Review of Economics and Statistics 80(4), 561-71. https://doi.org/10.1162/003465398557834.

Benhabib, J., and Spiegel, M. (1994). The Role of Human Capital in Economic Development. Evidence from Aggregate Cross-Country Data. Journal of Monetary Economics 144, 11743. https://doi.org/10.1016/0304-3932(94)90047-7.

Benhabib, J., and Spiegel, M. (2005). Human Capital and Technology Diffusion. In P. Aghion and S. Durlauf (Eds.). Handbook of Economic Growth. Elsevier. https://doi.org/10.1016/S1574-0684(05)01013-0.

Bergoeing, R., Loayza, N., and Piguillem, F. (2016). The Whole Is Greater than the Sum of Its Parts: Complementary Reforms to Address Microeconomic Distortions. World Bank Economic Review 30(2), 268-305. https://doi.org/10.1093/wber/lhv052.

Borensztein, E., De Gregorio, J., and Lee, J. (1998). How Does Foreign Direct Investment Affect Economic Growth? Journal of International Economics 45(1), 115-35. https://doi.org/10.1016/S0022-1996(97)00033-0.

Bridgman, B., Qi, S., and Schmitz, J. (2009). The Economic Performance of Cartels: Evidence from the New Deal U.S. Sugar Manufacturing Cartel, 1934-74. 437. Federal Reserve Bank of Minneapolis Staff Report.

Bronzini, R., and Piselli, P. (2009). Determinants of Long-Run Regional Productivity with Geographical Spillovers: The Role of R\&D, Human Capital and Public Infrastructure. Regional Science and Urban Economics 39(2), 187-99. https://doi.org/10.1016/j.regsciurbeco.2008.07.002.

Budescu, D. (1993). Dominance Analysis: A New Approach to the Problem of Relative Importance of Predictors in Multiple Regression. Psychological Bulletin. https://doi.org/10.1037/0033-2909.114.3.542.

Buera, F., Kaboski, J., and Shin, Y. (2011). American Economic Association Finance and Development: A Tale of Two Sectors. The American Economic Review 101(5), 1964-2002. https://doi.org/10.1257/aer.101.5.1964.

Caballero, R., and Hammour, M. (1998). Jobless Growth: Appropriability, Factor Substitution, and Unemployment. Carnegie-Rochester Conference Series on Public Policy 48, 95-99. https://doi.org/http://dx.doi.org/10.1016/S0167-2231(98)00016-5.

Caballero, R., and Hammour, M. (1996). On the Timing and Efficiency of Creative Destruction. The Quarterly Journal of Economics 111(3), 805-52. https://doi.org/10.2307/2946673. 
Calderón, C., and Servén, L. (2010). Infrastructure and Economic Development in Sub-Saharan Africa. Journal of African Economies 19 (Supplement 1), i13-i87. https://doi.org/10.1093/jae/ejp022.

Calderón, C., and Servén, L. (2012). Infrastructure in Latin America. The Oxford Handbook of Latin American Economics. Oxford: Oxford University Press. https://doi.org/10.1093/oxfordhb/9780199571048.013.0026.

Calderón, C., and Servén, L. (2014). Infrastructure, Growth, and Inequality: An Overview. 7034. World Bank Policy Research Working Paper. https://doi.org/10.1596/1813-9450-7034.

Canning, D., and Pedroni, P. (2008). Infrastructure, Long-Run Economic Growth and Causality Tests for Cointegrated Panels. Manchester School 76(5), 504-27. https://doi.org/10.1111/j.1467-9957.2008.01073.x.

Caselli, F. (2005). Accounting for Cross-Country Income Differences. In P. Aghion and S. Durlauf (Eds.). Handbook of Economic Growth. https://doi.org/10.1016/S1574-0684(05)01009-9.

Céspedes, N., Loayza, N., and Ramírez, N. (forthcoming). Economic Growth in Peru: Causes and Consequences [in Spanish]. Lima: Fondo Editorial de la Universidad del Pacífico.

Chanda, A., and Dalgaard, C. (2008). Dual Economies and International Total Factor Productivity Differences: Channelling the Impact from Institutions, Trade, and Geography. Economica 75(300), 629-61. https://doi.org/10.1111/j.1468-0335.2007.00673.x.

Chang, R., Kaltani, L., and Loayza, N. (2009). Openness Can Be Good for Growth: The Role of Policy Complementarities. Journal of Development Economics 90(1), 33-49. https://doi.org/10.1016/j.jdeveco.2008.06.011.

Chen, D., and Dahlman, C. (2004). Knowledge and Development A Cross-Section Approach. 3366. World Bank Policy Research Working Paper.

Chenery, H. (1960). Patterns of Industrial Growth. The American Economic Review 50(4), 62454. www.jstor.org/stable/1812463.

Cingano, F. (2014). Trends in Income Inequality and Its Impact on Economic Growth. OECD Social, Employment, and Migration Working Papers, no. 163(1), 5-59. https://doi.org/10.1787/5jxrjncwxv6j-en.

Coe, D., Helpman, E., and Hoffmaister, A. (2009). International R\&D Spillovers and Institutions. European Economic Review 53(7), 723-41. https://doi.org/10.1016/j.euroecorev.2009.02.005.

Coe, D., and Helpman, E. (1995). International R\&D Spillovers. European Economic Review 39(5), 859-87. https://doi.org/10.1016/0014-2921(94)00100-E.

Coe, D., Helpman, E., and Hoffmaister, A. (1997). North-South R\&D Spillovers. Economic Journal 107(440), 134-49. https://doi.org/10.1111/1468-0297.00146.

Comin, D., and Hobijn, B. (2010). An Exploration of Technology Diffusion. American Economic Review 100(5), 2031-59. https://doi.org/10.1257/aer.100.5.2031.

Comin, D., Hobijn, B., and Rovito, E. (2008). Technology Usage Lags. Journal of Economic Growth 13(4), 237-56. https://doi.org/10.1007/s10887-008-9035-5.

Comin, D., and Mestieri, M. (2018). If Technology Has Arrived Everywhere, Why Has Income Diverged? American Economic Journal: Macroeconomics 10(3), 137-78. 
https://doi.org/10.1257/mac.20150175.

Corrado, C., Hulten, C. and Sichel, D. (2009). Intangible Capital and U.S. Economic Growth. The Review of Income and Wealth 55(3), 661-685.

Dabla-norris, E., and Kochhar, K. (2015). Causes and Consequences of Income Inequality: A Global Perspective. IMF Staff Discussion Note.

Dar, A., and AmirKhalkhali, S. (2002). Government Size, Factor Accumulation, and Economic Growth: Evidence from OECD Countries. Journal of Policy Modeling 24(7-8), 679-92. https://doi.org/10.1016/S0161-8938(02)00163-1.

Davis, S., Haltiwanger, J., and Schuh, S. (1996). Small Business and Job Creation: Dissecting the Myth and Reassessing the Facts. Small Business Economics 8(4), 297-315. https://doi.org/10.1007/BF00393278.

Devadas, S., and Pennings, S. (2018). Assessing the Effect of Public Capital on Growth: An Extension of the World Bank Long-Term Growth Model. World Bank Policy Research Working Paper, No. 8604.

de Mello, L. (1999). Foreign Direct Investment-Led Growth: Evidence from Time Series and Panel Data. Oxford Economic Papers 51, 133-51. https://doi.org/10.1093/oep/51.1.133.

Djankov, S., La Porta, R., Lopez-de-Silanes, F., and Shleifer, A. (2002). The Regulation of Entry. The Quarterly Journal of Economics 117(1), 1-37.

Dollar, D., and Kraay, A. (2004). Trade, Growth, and Poverty. The Economic Journal 114(493), F22-49. https://doi.org/10.1111/j.0013-0133.2004.00186.x.

Easterly, W. (2001). The Middle Class Consensus and Economic Development. Journal of Economic Growth 6(4), 317-35. https://doi.org/10.1023/A:1012786330095.

Easterly, W., and Levine, R. (1997). Africa's Growth Tragedy. The Quarterly Journal of Economics 112(4), 1203-50. https://doi.org/10.1162/003355300555466.

Easterly, W., and Levine, R. (2003). Tropics, Germs, and Crops: How Endowments Influence Economic Development. Journal of Monetary Economics 50(1), 3-39. https://doi.org/10.1016/S0304-3932(02)00200-3.

Easterly, W., and Levine, R. (2001). It's Not Factor Accumulation: Stylized Facts and Growth Models. The World Bank Economic Review 15(2), 177-219. https://doi.org/10.2139/ssrn.269108.

Engerman, S., and Sokoloff, K. (2000). Institutions, Factor Endowments, and Paths of Development in the New World. Journal of Economic Perspectives 14(3), 217-32.

Erosa, A., Koreshkova, T., and Restuccia, D. (2010). How Important Is Human Capital? A Quantitative Theory Assessment of World Income Inequality. Review of Economic Studies 77(4), 1421-49. https://doi.org/10.1111/j.1467-937X.2010.00610.x.

Fagerberg, J. (2000). Technological Progress, Structural Change and Productivity Growth: A Comparative Study. Structural Change and Economic Dynamics 11(4), 393-411. https://doi.org/10.1016/S0954-349X(00)00025-4.

Feenstra, R., Inklaar, R., and Timmer, M. (2015). The next Generation of the Penn World Table. American Economic Review 105(10), 3150-82. https://doi.org/10.1257/aer.20130954.

Feyrer, J. (2007). Demographics and Productivity. The Review of Economics and Statistics 89(1), 
100-109.

Foster, L., Haltiwanger, J., and Krizan, C. (2001). Aggregate Productivity Growth. Lessons from Microeconomic Evidence. In C. Hulten, E. Dean and M. Harper (Eds.). New Developments in Productivity Analysis. University of Chicago Press, 303-372.

Furman, J., and Hayes, R. (2004). Catching up or Standing Still? National Innovative Productivity among 'follower' Countries, 1978-1999. Research Policy 33(9), 1329-54. https://doi.org/10.1016/j.respol.2004.09.006.

Galiani, S., Gertler, P., and Schargrodsky, E. (2005). Water for Life: The Impact of the Privatization of Water Services on Child Mortality. Journal of Political Economy 113(1), 83-120. https://doi.org/10.1086/426041.

Ghali, K. (1999). Government Size and Economic Growth: Evidence from a Multivariate Cointegration Analysis. Applied Economics 31(8), 975-87. https://doi.org/10.1080/000368499323698.

Giavazzi, F., and Tabellini, G. (2005). Economic and Political Liberalizations. Journal of Monetary Economics 52(7), 1297-1330. https://doi.org/10.1016/j.jmoneco.2005.05.002.

Griffith, R., Redding, S., and Van Reenen, J. (2004). Mapping the Two Faces of R\&D: Productivity Growth in a Panel of OECD Industries. The Review of Economics and Statistics 86(4), 883-95. https://doi.org/10.1162/0034653043125194.

Grömping, U. (2007). Estimators of Relative Importance in Linear Regression Based on Variance Decomposition. American Statistician 61(2), 139-47. https://doi.org/10.1198/000313007X188252.

Grossman, G., and Helpman, E. (1991). Quality Ladders in the Theory of Growth. The Review of Economic Studies 58(1), 43-61. https://doi.org/10.2307/2298044.

Guellec, D., and van Pottelsberghe de la Potterie, B. (2004). From R\&D to Productivity Growth: Do the Institutional Settings and the Source of Funds of R\&D Matter? $O x$ ford Bulletin of Economics and Statistics 66(3), 353-78. https://doi.org/10.1111/j.14680084.2004.00083.x.

Hall, R., and Jones, C. (1999). Why Do Some Countries Produce so Much More Outper per Worker than Others? Quarterly Journal of Economics 114(1), 83-116. https://doi.org/10.1162/003355399555954.

Haltiwanger, J., Scarpetta, S., and Schweiger, H. (2008). Assessing Job Flows across Countries: The Role of Industry, Firm Size and Regulations. 13920. NBER Working Paper. http://doi.org/10.3386/w13920.

Hanushek, E., and Woessmann, L. (2015). The Knowledge Capital of Nations: Education and the Economics of Growth. Cambridge, MA: MIT Press.

Hicks, J. (1939). Value and Capital. Oxford: Clarendon Press.

Hoeller, P., Joumard, I., and Koske, I. (2014). Reducing Income Inequality While Boosting Economic Growth: Can It Be Done? Evidence from OECD Countries. The Singapore Economic Review 59(01), 1450001. https://doi.org/10.1142/S0217590814500015.

Hopenhayn, H. (1992). Entry, Exit, and Firm Dynamics in Long Run Equilibrium. Econometrica $60(5), 1127-50$. 
Hopenhayn, H., and Rogerson, R. (1993). Job Turnover and Policy Evaluation: A General Equilibrium Analysis. Journal of Political Economy 101(5), 915-38. https://doi.org/10.1086/261909.

Hsieh, C., and Klenow, P. (2009). Misallocation and Manufacturing TFP in China and India. Quarterly Journal of Economics 124(4), 1403-48. https://doi.org/10.1162/qjec.2009.124.4.1403.

Hulten, C. (2001). Total Factor Productivity: A Short Biography. In C. Hulten, E. Dean, and M. Harper (Eds.). Chicago: University of Chicago Press. New Developments in Productivity Analysis.

Hulten, C. (1996). Infrastructure Capital and Economic Growth How Well You Use It May Be More Important Than How Much You Have. 5847. NBER Research Working Paper. https://doi.org/10.3386/w5847.

International Road Federation. (2017a). Roads, Paved ( \% of Total Roads). International Road Federation. 2017.

International Road Federation. (2017b). Roads, Total Network (Km). International Road Federation. 2017.

Isaksson, A. (2007). Determinants of Total Factor Productivity: A Literature Review. Research and Statistics Branch, UNIDO.

http://www.rrojasdatabank.info/87573_determinants_of_total_factor_productivity.pdf.

Jerzmanowski, M. (2007). Total Factor Productivity Differences: Appropriate Technology vs. Efficiency. European Economic Review 51(8), 2080-2110. https://doi.org/10.1016/j.euroecorev.2006.12.005.

Jolliffe, I. (2002). Principal Component Analysis. Springer Series in Statistics. Nueva York: Springer Press. https://doi.org/10.1007/b98835.

Jorgenson, D., Ho, M., and Stiroh, K. (2005). Productivity, Volume 3: Information Technology and the American Growth Resurgence. Cambridge, MA: MIT Press. http://ideas.repec.org/b/mtp/titles/0262101114.html.

Jorgenson, D., Ho, M., and Stiroh, K. (2008). A Retrospective Look at the US Productivity Growth Resurgence. Journal of Economic Perspectives 22(1), 3-24. https://doi.org/10.1257/jep.22.1.3.

Jorgenson, D., and Griliches, Z. (1967). The Explanation of Productivity Change. Review of Economic Studies 34, 349-83.

Kaufmann, D., and Kraay, A. (2017). Worldwide Governance Indicators. World Bank. 2017. www.govindicators.org, accessed on 31 May 2017.

Kim, Y., Loayza, N., and Meza-Cuadra, C. (2016). Productivity as the Key to Economic Growth and Development. World Bank Research Policy Brief, no. 3. http://documents.worldbank.org/curated/en/314741472533203058/Productivity-asthe-key-to-economic-growth-and-development.

Knack, S., and Keefer, P. (1995). Institutions and Economic Performance: Cross-country Tests Using Alternative Institutional Measures. Economics $\&$ Politics 7(3), 207-27. https://doi.org/10.1111/j.1468-0343.1995.tb00111.x. 
Kremer, M., Rao, G., and Schilbach, F. (2019). Behavioral Development Economics. In B. Bernheim, S. DellaVigna, and D. Laibson (Eds.). Handbook of Behavioral Economics - Foundations and Applications 2, 1st ed.. North Holland - Elsevier, 345-458. https://doi.org/10.1016/bs.hesbe.2018.12.002.

Kuznets, S. (1957). Quantitative Aspects of the Economic Growth of Nations: II. Industrial Distribution of National Product and Labor Force. Economic Development and Cultural Change 5(S4), 1-111. https://doi.org/10.1086/449740.

Lentz, R., and Mortensen, D. (2008). An Empirical Model of Growth through Product Innovation. Econometrica 76(6), 1317-73. https://doi.org/10.3982/ECTA5997.

Lewis, A. (1954). Economic Development with Unlimited Supplies of Labour. The Manchester School 22(2), 139-91. https://doi.org/10.1111/j.1467-9957.1954.tb00021.x.

Loayza, N., and Pennings, S. (2018). The Long Term Growth Model. World Bank: Washington D.C. 2018. http://www.worldbank.org/LTGM.

Loayza, N., and Odawara, R. (2010). Infrastructure and Economic Growth in Egypt. World Bank Policy Research Working Paper. https://doi.org/10.1177/097493060900100105.

Loayza, N., Fajnzylber, P., and Calderón, C. (2005). Economic Growth in Latin America and the Caribbean: Stylized Facts, Explanations, and Forecasts. Washington, DC: World Bank.

Loayza, N., and Servén, L. (2010). Business Regulation and Economic Performance. World Bank Publications, No. 2554.

Lucas, R. (1988). On the Mechanics of Economic Development. Journal of Monetary Economics 22(1), 3-42. https://doi.org/10.1016/0304-3932(88)90168-7.

Mastromarco, C., and Zago, A. (2012). On modeling the determinants of TFP growth. Structural Change and Economic Dynamics 23(4), 373-382.

Mauro, P. (1995). Corruption and Growth. The Quarterly Journal of Economics 110(3), 681-712. https://doi.org/10.2307/2946696.

Melitz, M. (2003). The Impact of Trade on Intra-Industry Reallocations and Aggregate Industry Productivity. Econometrica 71(6), 1695-1725.

Mendi, P. (2007). Trade in Disembodied Technology and Total Factor Productivity in OECD Countries. Research Policy 36(1), 121-33. https://doi.org/10.1016/j.respol.2006.09.028.

Miller, S., and Upadhyay, M. (2000). The Effects of Openness, Trade Orientation, and Human Capital on Total Factor Productivity. Journal of Development Economics 63(2), 399-423. https://doi.org/10.1016/S0304-3878(00)00112-7.

Mulaik, S. (2009). Foundations of Factor Analysis. 2nd edition. Boca Raton: Taylor \& Francis Group, LLC.

Munnell, A. (1992). Policy Watch: Infrastructure Investment and Economic Growth. Journal of Economic Perspectives 6(4), 189-98. https://doi.org/10.1257/jep.6.4.189.

Nadiri, M. (1993). Innovations and Technological Spillovers. 4423. NBER Working Paper. https://doi.org/10.3386/w4423.

Nicoletti, G., and Scarpetta, S. (2003). Regulation, Productivity and Growth: OECD Evidence. Economic Policy 18(36), 9-72. https://doi.org/10.1111/1468-0327.00102.

North, D. (1990). Institutions, Institutional Change and Economic Performance. Cambridge: 
Cambridge University Press.

OECD/IEA. (2017). Electricity Production (KWh). OECD/IEA. 2017.

OECD. (2016a). PISA: Mean Performance on the Mathematics Scale. 2016.

OECD. (2016b). PISA: Mean Performance on the Reading Scale. 2016.

OECD. (2016c). PISA: Mean Performance on the Science Scale. 2016.

Oliner, S., Sichel, D., and Stiroh, K. (2008). Explaining a Productive Decade. Journal of Policy Modeling 30(4), 633-73. https://doi.org/10.1016/j.jpolmod.2008.04.007.

Parente, S., and Prescott, E. (2000). Barriers to Riches. Cambridge, MA: MIT Press.

Peneder, M. (2003). Industrial Structure and Aggregate Growth. Structural Change and Economic Dynamics 14(4), 427-48. https://doi.org/10.1016/S0954-349X(02)00052-8.

Petrin, A., and Sivadasan, J. (2011). Estimating Lost Output from Allocative Inefficiency, with an Application to Chile and Firing Costs. Review of Economics and Statistics 95(1), 286-301. https://doi.org/10.1162/REST_a_00238.

Pritchett, L. (1996). Mind Your P's and Q's: The Cost of Public Investment Is Not the Value of Public Capital. World Bank Policy Research Working Paper. https://doi.org/10.1596/1813-9450-1660.

Przeworski, A, and Limongi, F. (1993). Political Regimes and Economic Growth. Journal of Economic Perspectives 7(3), 51-69. https://doi.org/10.1257/jep.7.3.51.

Rajan, R., and Zingales, L. (1998). Financial Dependence and Growth. American Economic Review 88(3), 559-86.

Rebelo, S. (1991). Long-Run Policy Analysis and Long-Run Growth. Journal of Political Economy 99(3), 500-521. https://doi.org/10.1086/261764.

Restuccia, D., and Rogerson, R. (2008). Policy Distortions and Aggregate Productivity with Heterogeneous Establishments. Review of Economic Dynamics 11(4), 707-20. https://doi.org/10.1016/j.red.2008.05.002.

Restuccia, D., and Rogerson, R. (2017). The Causes and Costs of Misallocation. Journal of Economic Perspectives 31(3), 151-74.

Rodrik, D., Subramanian, A., and Trebbi, F. (2004). Institutions Rule: The Primacy Over in Economic and Integration Geography Development. Journal of Economic Growth 9(2), $131-65$.

Romer, P. (1987). Growth Based on Increasing Returns Due to Specialization. The American Economic Review 77(2), 56-62. https://www.jstor.org/stable/1805429.

Romer, P. (1990). Endogenous Technological Change. Journal of Political Economy 98(5), S71S102. https://doi.org/10.1086/261725.

Sachs, J. (2003). Institutions Don't Rule: Direct Effects of Geography on per Capita Income. 9490. NBER Working Paper.

SAS Institute Inc. (2017). Principal Components or Factor Analysis? 2017. https://community.jmp.com/t5/JMP-Blog/Principal-components-or-factor-analysis/bcp/50703\#M3325, accessed on 15 March 2018.

Schumpeter, J. (1942). Capitalism, Socialism and Democracy. New York: Harper \& Row.

Solow, R. (1956). A Contribution to the Theory of Economic Growth. The Quarterly Journal of 
Economics 70(1), 65-94. https://doi.org/10.2307/1884513.

Straub, S. (2008). Infrastructure and Growth in Developing Countries: Recent Advances and Research Challenges. 4460. World Bank Policy Research Working Paper. https://doi.org/10.1596/1813-9450-4460.

Svirydzenka, K. (2016). Introducing a New Broad-Based Index of Financial Development. 16/5. IMF Working Paper.

Swan, T. (1956). Economic Growth and Capital Accumulation. Economic Record 32(2), 334-61. https://doi.org/10.1111/j.1475-4932.1956.tb00434.x.

Syverson, C. (2011). What Determines Productivity? Journal of Economic Literature 49(2), 326-65. https://doi.org/10.1257/jel.49.2.326.

Ulku, H., and Subramanian, A. (2004). R\&D, Innovation, and Economic Growth: An Empirical Analysis. 04/185. IMF Working Paper. https://doi.org/10.5089/9781451859447.001.

van Ark, B., O'Mahony, M., and Timmer, M. (2008). The Productivity Gap between Europe and the United States: Trends and Causes. Journal of Economic Perspectives 22(1), 2544. https://doi.org/10.1257/jep.22.1.25.

Wei, Z., and Hao, R. (2011). The Role of Human Capital in China's Total Factor Productivity Growth: A Cross-Province Analysis. The Developing Economies 49(1), 1-35. https://doi.org/10.1111/j.1746-1049.2010.00120.x.

WHO/UNICEF. (2017a). Improved Sanitation Facilities (\% of Population with Access). 2017.

WHO/UNICEF. (2017b). Improved Water Source (\% of Population with Access). 2017.

Woo, W., Parker, S., and Sachs, J. (1997). Economies in Transition: Comparing Asia and Europe. Cambridge, MA: MIT Press.

World Bank. (2003). World Development Report 2004: Making Services Work for Poor People. World Bank. https://openknowledge.worldbank.org/handle/10986/5986.

World Bank. (2017a). Doing Business 2017: Equal Opportunity for All. Washington, DC: World Bank Group. https://doi.org/10.1596/978-1-4648-0948-4.

World Bank. (2017b). Employment to Population Ratio, 15+, Total (\%) (Modeled ILO Estimate). World Development Indicators. 2017.

World Bank. (2017c). Fixed Telephone Subscriptions (per 100 People). World Development Indicators. 2017.

World Bank. (2017d). GDP (Constant 2010 US\$). World Development Indicators. 2017.

World Bank. (2017e). GDP per Capita (Constant 2010 US\$). World Development Indicators. 2017.

World Bank. (2017f). Government Expenditure on Education, Total. World Development Indicators. 2017.

World Bank. (2017g). Gross Capital Formation (Constant 2010 US\$). World Development Indicators. 2017.

World Bank. (2017h). Labor Market Regulation Indicators. Doing Business Database. 2017.

World Bank. (2017i). Mobile Cellular Subscriptions (per 100 People). World Development Indicators. 2017.

World Bank. (2017j). Oil Rents (\% of GDP). World Development Indicators. 2017. 
World Bank. (2017k). Patent Applications, Nonresidents. World Development Indicators. 2017.

World Bank. (2017l). Patent Applications, Residents. World Development Indicators. 2017.

World Bank. (2017m). Population, Total. World Development Indicators. 2017.

World Bank. (2017n). Population Ages 0-14 (\% of Total). World Development Indicators. 2017.

World Bank. (2017o). Research and Development Expenditure (\% of GDP). World Development Indicators. 2017.

World Bank. (2017p). Scientific and Technical Journal Articles. World Development Indicators. 2017.

World Bank. (2017q). Share of Women in Wage Employment in the Nonagricultural Sector (\% of Total Nonagricultural Employment). World Development Indicators. 2017.

World Bank. (2017r). World Development Report 2017: Governance and the Law. World Bank. http://www.worldbank.org/en/publication/wdr2017.

Young, A. (2017). Consistency without Inference: Instrumental Variables in Practical Application. London School of Economics Working Paper. http://personal.lse.ac.uk/YoungA/ConsistencyWithoutInference.pdf. 